\title{
The Miocene Tatatila-Las Minas IOCG skarn deposits (Veracruz) as a result of adakitic magmatism in the Trans-Mexican Volcanic Belt
}

Los depósitos de tipo skarn IOCG miocénicos de Tatatila-Las Minas (Veracruz) como resultado del magmatismo adakítico de la Faja Volcánica Trans-Mexicana

\author{
Edith Fuentes-Guzmán ${ }^{1,2,3}$, Eduardo González-Partida ${ }^{4}$, Antoni Camprubí1 ${ }^{1,3 *}$, \\ Geovanny Hernández-Avilés ${ }^{2}$, Janet Gabites ${ }^{5}$, Alexander Iriondo ${ }^{4,6}$, Giovanni Ruggieri ${ }^{7}$, \\ Margarita López-Martínez ${ }^{8}$
}

\begin{abstract}
Instituto de Geología, Universidad Nacional Autónoma de México. Ciudad Universitaria, 04510 Coyoacán, CDMX, Mexico.

${ }^{2}$ Programa de Posgrado en Ciencias de la Tierra, Universidad Nacional Autónoma de México. Ciudad Universitaria, 04510 Coyoacán, CDMX / Boulevard Juriquilla 3001, 76230 Juriquilla, Querétaro, Mexico.

Laboratorio Nacional de Geoquímica y Mineralogía (LANGEM). Ciudad Universitaria, 04510 Coyoacán, CDMX, Mexico.

${ }^{4}$ Centro de Geociencias, Universidad Nacional Autónoma de México. Boulevard Juriquilla 3001, 76230 Juriquilla, Querétaro, Mexico.

${ }^{5}$ Pacific Centre for Isotopic and Geochemical Research, Department of Earth, Ocean and Atmospheric Sciences, University of British Columbia; Earth Sciences Building, 2207 Main Mall, Vancouver, V6T 1Z4, British Columbia, Canada.
\end{abstract}

Department of Geosciences, University of Arizona. 1040 E 4th Street, 85721, Tucson, Arizona,USA.

${ }^{7}$ Istituto di Geoscienze e Georisorse, Consiglio Nazionale delle Ricerche. Via G. Moruzzi 1, 56124 Pisa, Italy.

${ }^{8}$ Centro de Investigación Científica y Estudios Superiores de Ensenada. Carretera Tijuana-Ensenada km. 107, 22860 Ensenada, Baja California, Mexico.

* Corresponding author: (A. Camprubí)

camprubi@comunidad.unam.mx

\section{How to cite this article:}

Fuentes-Guzmán, E., González-Partida, E., Camprubí, A., Hernández-Avilés, G., Gabites, J., Iriondo, A., Ruggieri, G., López-Martínez, M., 2020, The Miocene Tatatila-Las Minas IOCG skarn deposits (Veracruz) as a result of adakitic magmatism in the Trans-Mexican Volcanic Belt: Boletín de la Sociedad Geológica Mexicana, 72 (3), Al10520. http://dx.doi. org/10.18268/BSGM2020v72n3a110520

Manuscript received: October 28, 2020

Corrected manuscript received: May 1, 2020

Manuscript accepted: May 10, 2020

Peer Reviewing under the responsibility of Universidad Nacional Autónoma de México.

This is an open access article under the CC BY-NC-SA license(https://creativecommons.org/licenses/by-nc-sa/4.0/)

\section{ABSTRACT}

The Cu- and Au-rich Tatatila-Las Minas IOGG skarn deposits in Veracruz (central-east Mexico) are circumscribed to the earliest stages of the Trans-Mexican Volcanic Belt (TMVB) and stand for a metallogenic province directly linked to its tectonomagmatic dynamics. This is the first well-documented case for such metallogenic province. These deposits were formed as skarns between rocks of the Mesozoic carbonate series and Miocene intermediate to acid hypabyssal rocks. New U-Pb zircon and ${ }^{40} \mathrm{Ar} /{ }^{39} \mathrm{Ar}$ ages provide evidence for four epochs of magmatic activity in the area: (1) early Permian (Artinskian), in association with the Paleozoic basement, (2) late Oligocene to early Miocene suite of pre-TMVB intrusive rocks, (3) middle to late Miocene suite of early TMVB-related intrusive rocks, and (4) Pliocene intrusive and extrusive rocks of the TMVB, possibly associated with the Los Humeros post-caldera stage. The obtained ages range between $24.60 \pm 1.10$ and $19.04 \pm$ $0.69 \mathrm{Ma}$ for stage 2, and between $16.34 \pm 0.20$ and $13.92 \pm 0.22 \mathrm{Ma}$ for stage 3. Stage 2 corresponds to a magmatic stage unheard of in the area, until this study. Only stage 3 rocks are associated with the IOCG skarn mineralization, with retrograde stages dated at $12.44 \pm 0.09$ (chromian muscovite, phyllic association) and $12.18 \pm 0.21 \mathrm{Ma}$ (zircon, potassic association). Therefore, the ages of stage- 3 intrusive rocks are interpreted to date the formation of

\section{RESUMEN}

Los skarns IOCG ricos en $\mathrm{Cu}$ y $\mathrm{Au}$ de Tatatila-Las Minas en Veracruz (centro-oriente de México) están circunscritos a los estadíos más tempranos de la Faja Volcánica Transmexicana (FVTM) e indican directamente la existencia de una provincia metalogenética vinculada a su dinámica tectonomagmática. Este es el primer caso bien documentado para dicha provincia metalogenética. Estos depósitos se formaron como skarns entre rocas de la secuencia carbonatada del Mesozoico y rocas hipabisales indermedias a ácidas del Mioceno. Los nuevos fechamientos $U-P b$ en zircón y ${ }^{40} \mathrm{Ar} /{ }^{39} \mathrm{Ar}$ evidencian la existencia de cuatro épocas de actividad magmática en el área: (1) en el Pérmico temprano (Artinskiano), en asociación con el basamento paleozoico de las secuencias del Mesozoico, (2) un conjunto de intrusivos pre-FVTM entre del Oligoceno tardío y el Mioceno temprano, (3) un conjunto de intrusivos del Mioceno medio y tardío asociados a la FVTM, y (4) rocas intrusivas extrusivas del Plioceno de la FVTM, posiblemente asociadas a los depósitos del estadio post-caldera de Los Humeros. Las edades obtenidas varían entre $24.60 \pm 1.10$ y $19.04 \pm 0.69$ Ma para el estadío 2 , y entre $16.34 \pm 0.20$ y 13.92 \pm 0.22 Ma para el estadío 3. El estadío 2 corresponde a una etapa magmática hasta el presente estudio desconocida en el área. Sólo las rocas del estadio 3 están asociadas a las mineralizaciones de skarn IOCG, cuyas etapas retrógradas han sido fechadas en 12.44 \pm 0.09 (moscovita crómica, asociación filica) y $12.18 \pm 0.21 \mathrm{Ma}$ (zircón, asociación potásica). Por tanto, las edades de las rocas intrusivas del estadío 3 se interpretan como parte de las asociaciones de skarn prógrado (mayormente, de $\sim 15.4 a<14 \mathrm{Ma}$ ). 
the prograde skarn associations (mostly $\sim 15.4$ to $<14 \mathrm{Ma}$ ). The petrogenetic affinity of stage- 2 and stage- 3 rocks is about the same - the main difference has to do with higher $\mathrm{Y}$ and $\mathrm{Yb}$ contents in stage- 3 rocks (although no affinity with within-plate granites was found), which is suggestive of an interaction of their parental magmas with alkaline magmas that most likely belong to the conterminous and contemporaneous Eastern Mexico Alkaline Province. Petrological indicators (elemental and isotopic) in Cenozoic rocks consistently point to intermediate to acid, metaluminous, I- and S-type rocks that were emplaced in a subduction-related continental arc, within the medium- to high-potassium calc-alkaline series, with high-silica adakitic signatures due associated to deep-sourced magmas that underwent crustal contamination to some degree. The various possible sources for the magmas with adakitic signature in this context can be narrowed down to two of them that are not mutually exclusive: adakitic derived from subducted slab melting and melting-assimilation-storage-homogenization (MASH)-derived adakites. Both sources are, in principle, capable of generating magmas that would eventually produce magmatic-hydrothermal mineralizing systems with an associated variety of ore deposit types, including IOCG. Also, both possible sources for adakites are compatible with the renewed steepening of the subducted slab after a period of flat subduction, for the earliest stage in the evolution of the TMVB.

Keywords: IOGG, adakites, Miocene, TransMexican Volcanic Belt, skarn, magmatic-hydrothermal, iron oxides.
La afinidad petrogenética de las rocas correspondientes a los estadíos 2 y 3 es prácticamente la misma - su principal diferencia estriba los contenidos más altos de $\mathrm{Y}$ e $\mathrm{Yb}$ en rocas del estadío 3 (aunque no se encontró afinidad alguna con granitos de intraplaca), lo cual sugiere la interacción de sus magmas primigenios con magmas alcalinos que posiblemente pertenecieron a la contigua y contemporánea Provincia Alcalina Oriental Mexicana. Los indicadores petrogenéticos (elementales e isotópicos) en las rocas del Cenozoico apuntan consistentemente a rocas intermedias a ácidas, metalumínicas, de tipo Iy $S$, emplazadas en un arco continental debido a subducción y pertenecen a las series calci-alcalinas de potasio medio a alto, con (mayormente) firmas de adakitas altas en sílice debidas a un origen profundo de magmas que experimentaron cierto grado de contaminación cortical. La diversidad de posibles orígenes para las fimas adakiticas en este contexto pueden reducirse a sólo dos de ellas, que no son mutuamente exclusivas: adakitas derivadas de la fusión de la placa subducida y adakitas derivadas de procesos tipo fusión-asimilación-almacenamiento-homogeneización (MASH, por sus siglas en inglés). Ambas fuentes, en principio, poseen la capacidad de generar magmas que eventualmente pudieran producir sistemas mineralizantes magmático-hidrotermales con una cierta variedad de tipos de depósitos minerales asociados, incluyendo depósitos IOCG. Además, ambas posibles fuentes de adakitas son compatibles con la reverticalización de la placa subducida tras un periodo de subducción plana para el estadío más temprano en la evolución de la FVTM.

Palabras clave: IOCG, adakitas, Mioceno, Faja Volcánica Transmexicana, skarn, magmático-hidrotermal, óxidos de hierro.

\section{Introduction}

Recent assessment has shown that the metallogenic potential of the mid-Miocene to Holocene Trans-Mexican Volcanic Belt (TMVB) and the potential of Miocene to Holocene ore deposits in Mexico are greater than previously believed (Camprubí, 2009, 2013; Clark and Fitch, 2009; Poliquin, 2009; Jansen et al., 2017; Camprubí et al., 2019, 2020; Fuentes-Guzmán et al., 2020). The metallogeny of Miocene to Holocene epochs in Mexico is, in fact, distributed across several regions, namely (1) the southernmost part of the Sierra Madre Occidental, in association with its last ignimbritic flare-up, (2) the Trans-Mexican Volcanic Belt (TMVB), (3) the southern part of the Eastern Mexico Alkaline Province (EMAP) and northern Chiapas, (4) the easternmost part of the Sierra Madre del Sur (in Oaxaca), and (5) the Gulf of California. As (a) the easternmost ending of the TMVB coincides with the N-S geographic distribution of the EMAP, (b) the metallogeny of the TMVB is still poorly understood, and (c) there is a wide variety of types of ore deposits across the EMAP - including, skarns, metalliferous porphyries, epithermal deposits, IOCG deposits and carbonatites-, the identification of whether an ore deposit in such a region is geologically associated with the TMVB or the EMAP is not a straightforward task.

The Tatatila-Las Minas district in Veracruz State is located precisely in the region in which the TMVB and the EMAP overlap geographically, in the Palma Sola area. The ore deposits in the 
Tatatila-Las Minas have a magmatic-hydrothermal origin and are essentially $\mathrm{Cu}-\mathrm{Au}$ iron oxide skarns, part of the IOCG "clan", and epithermal deposits (Camprubí, 2013). Therefore, in order to investigate the origin of these deposits, the first necessary step would be to elucidate their genetic affinity with either magmatic province. Camprubí (2013) deduced a plausible age of $\sim 11 \mathrm{Ma}$ and some affinity with alkaline magmatism for the deposits in the Tatatila-Las Minas district, based on Negendank et al. (1985) and Ferrari et al. (2005a), which linked the Palma Sola massif with the EMAP. However, the middle Miocene to Recent alkaline and calc-alkaline volcanism of the Palma Sola area was ascribed to the TMVB, and to the subduction along the Pacific trench, as in Besch et al. (1988), Gómez-Tuena et al. (2003), and Orozco-Esquivel et al. (2007). The relevance of the EMAP, besides its petrotectonic affinity, as a major metallogenic province was already stressed by Camprubí (2009, 2013). However, the age of magmatism with which these ore deposits were plausibly associated corresponds well to the middle and late Miocene arc at the beginning of the TMVB ( 19 to $10 \mathrm{Ma}$; Gómez-Tuena et al., 2005, 2007).

In summary, we may use as a starting hypothesis the fact that neither the EMAP nor the TMVB are implausible magmatic provinces to have produced the parental magmatism to the Tatatila-Las Minas deposits. The implications for regional mineral exploration that may arise from either possibility are very different, nonetheless. In this paper, we analyze the petrologic affinity of the hypabyssal intrusive bodies with which the formation of the IOCG deposits of the Tatatila-Las Minas district is associated. This will enable a discrimination between the ascription of these deposits to the metallogeny of the TMVB or the EMAP. The proximal-to-source character of these magmatic-hydrothermal deposits (i.e., iron skarns) allows to soundly elucidate the linkage between the magmatism and the hydrothermal activity that generated the deposits. In addition, this paper contributes to a long-standing program that aims to the geochronological characterization of Mexican mineral deposits and the geologic events with which they are genetically associated (Camprubí et al., 2015, 2016a, 2016b, 2017, 2018, 2019, 2020; Farfán-Panamá et al., 2015; Martínez-Reyes et al., 2015; González-Jiménez et al., 2017a, 2017b; Enríquez et al., 2018; Fuentes Guzmán et al., 2020) to better constrain the metallogenic evolution of Mexico, as documented by Camprubí (2009, 2013, 2017).

\section{Geological setting}

The Tatatila-Las Minas mining district is located in the central-eastern part of the state of Veracruz (Figure 1) within the Palma Sola massif. It is characterized by the intrusion of Neogene stocks. Stock compositions are described to vary between gabbro and granodiorite, with dominantly monzodioritic to dioritic compositions, and intruded middle Jurassic, red beds and lower Cretaceous carbonate rocks. The latter rocks are part of the continental to marine sequences of the Sierra Madre Oriental that were deformed during the orogenic pulses of the Mexican Fold-and-Thrust Belt between the late Cretaceous and the Paleocene (Centeno-García, 2017; Fitz-Díaz et al., 2018; and references therein). The Middle Jurassic red bed sequence in the area correlates with the Cahuasas Formation, and is overlain by carbonates and lutites of the Pimienta (Tithonian-Barriasian) and Orizaba (Albian-Cenomanian) formations. The host carbonate series in the study area consists essentially of platform carbonates that correspond to the Orizaba Formation (Ortuño-Arzate et al., 2005). The Lower Cretaceous sequence unconformably overlies Permo-Triassic schists intruded by granitic rocks. The latter can be mistaken for Neogene intrusive bodies with similar compositions, as the thick vegetation cover commonly hinders their visualization and the identification of the lithologic contacts; both groups of intrusive rocks come in contact by faulting in the northern- 
most termination of the mineralized area (Figure 1). The Mesozoic sedimentation was controlled by the horst-and-graben configuration that resulted from the opening of the Gulf of Mexico during the breakup of Pangea (Martini and Ortega-Gutiérrez, 2018), thus developing simultaneously shallow platforms and relatively deep open-sea facies, hence the Córdoba platform (Ortuño-Arzate et al., 2005) on which the upper Jurassic and Lower Cretaceous sedimentary units developed.

Neogene intrusive bodies generated typical skarn associations, with prograde mineralization by contact metamorphism (Ca silicate-rich) that was followed by retrograde IOCG-type hydrothermal stages of mineralization (Figure 2). Such intrusive bodies made up a NE-SW striking 20 km long and $\sim 10 \mathrm{~km}$ wide intrusive ensemble whose composition varies from gabbro to granodiorite, with dominantly monzodioritic to dioritic compositions (see below) with phaneritic textures. These rocks typically contain hornblende, biotite, pyroxenes, apatite and zircon this two as accessory mineral (Figure 3). Some andesite dykes, up to $30 \mathrm{~m}$ long and $\sim 2 \mathrm{~m}$ thick crosscut the intrusive ensemble and predate the mineralization. A sequence of andesitic, basaltic and dacitic hypabyssal, this with porphyritic texture include plagioclase phenocrysts and volcanic rocks postdates the mineralization and the emplacement of the associated intrusive rocks, and comprises a variety of depos-

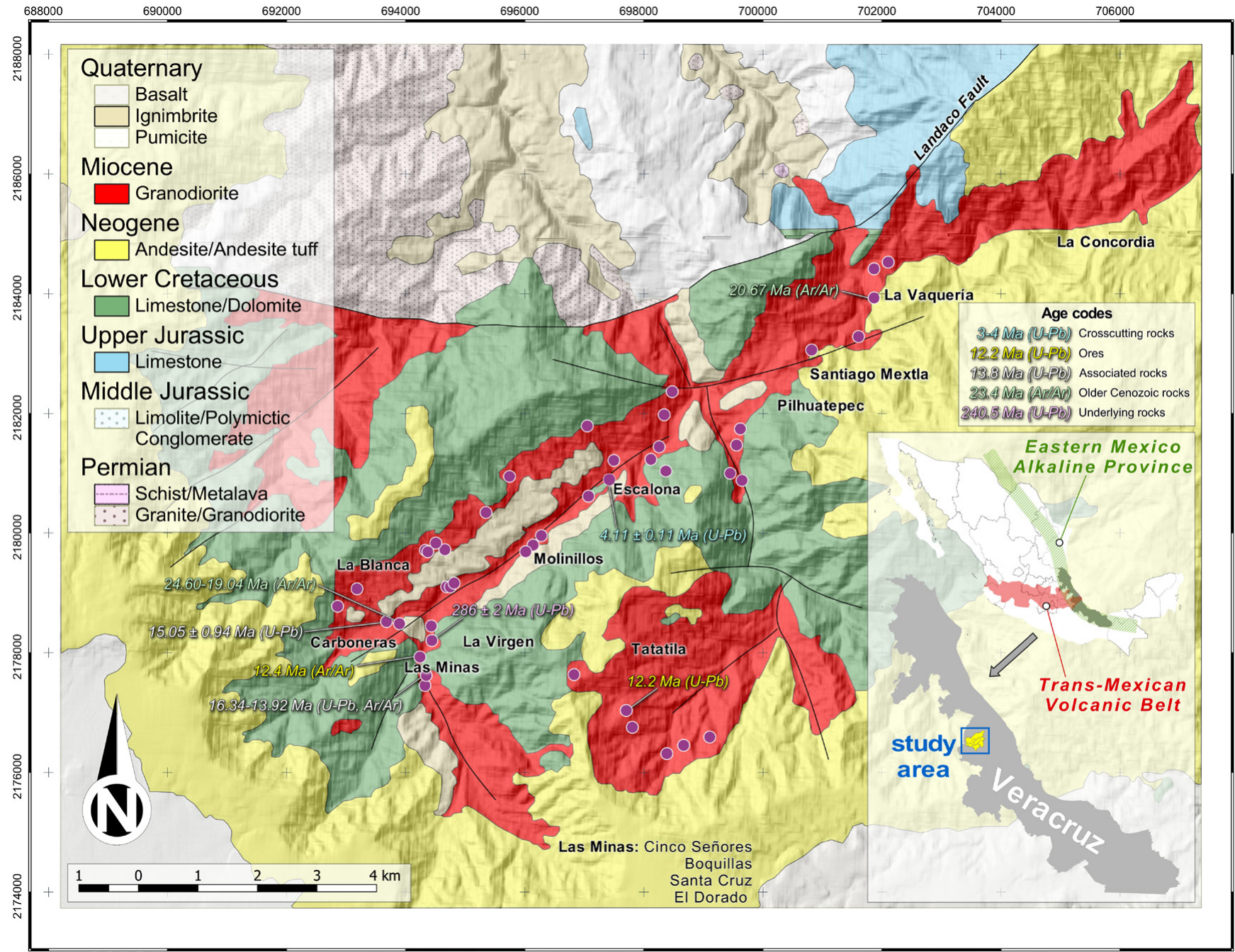

Figure 1 Geological map of the Tatatila-Las Minas mining district, east of the Palma Sola massif. Adapted from Servicio Geológico Mexicano $(2007,2010)$. Purple circles denote the location of samples on which this study is based, with indication of the obtained ages. 
its, including volcanic conglomerates, tuffs, ash-fall and pyroclastic deposits. Such rocks are interpreted as distal Pliocene deposits associated with the post-caldera deposits of Los Humeros caldera (Carrasco-Nuñez et al., 2018; Dorantes-Castro, 2016; Sarabia-Jacinto, 2017). Ages for the Palma Sola area to the east of the Tatatila-Las Minas area were $14.6 \pm 0.3(\mathrm{U}-\mathrm{Pb}$, zircon $)$ and $11 \pm 0.87 \mathrm{Ma}$ (K-Ar, biotite), were reported by Poliquin (2009) and Murillo-Muñetón and Torres-Vargas (1987), respectively. These correspond to the ensemble of hypabyssal and volcanic rocks that allowed Camprubí (2013) to deduce a tentative age of $\sim 11 \mathrm{Ma}$ for these ore deposits, which is also constrained by the formation of capping volcanic rocks between 9 and 6.6 Ma. Contact metamorphism and mineralization of the fresh carbonate rocks can be observed in the conspicuous formation of marble in a 300 to $400 \mathrm{~m}$ wide zone that shows an outward decreasing degree of recrystallization. Skarn associations are distributed in the classic zonation from endoskarn to exoskarn. Endoskarns consist of grossular-andradite, clinopyroxene, and quartz in prograde associations, and magnetite, chalcopyrite, bornite, and native gold in retrograde associations (Figure 2). Exoskarns consist of wollastonite, clinopyroxene, potassium feldspar, quartz, epidote, and chromian muscovite ("fuchsite"; Figure 2).
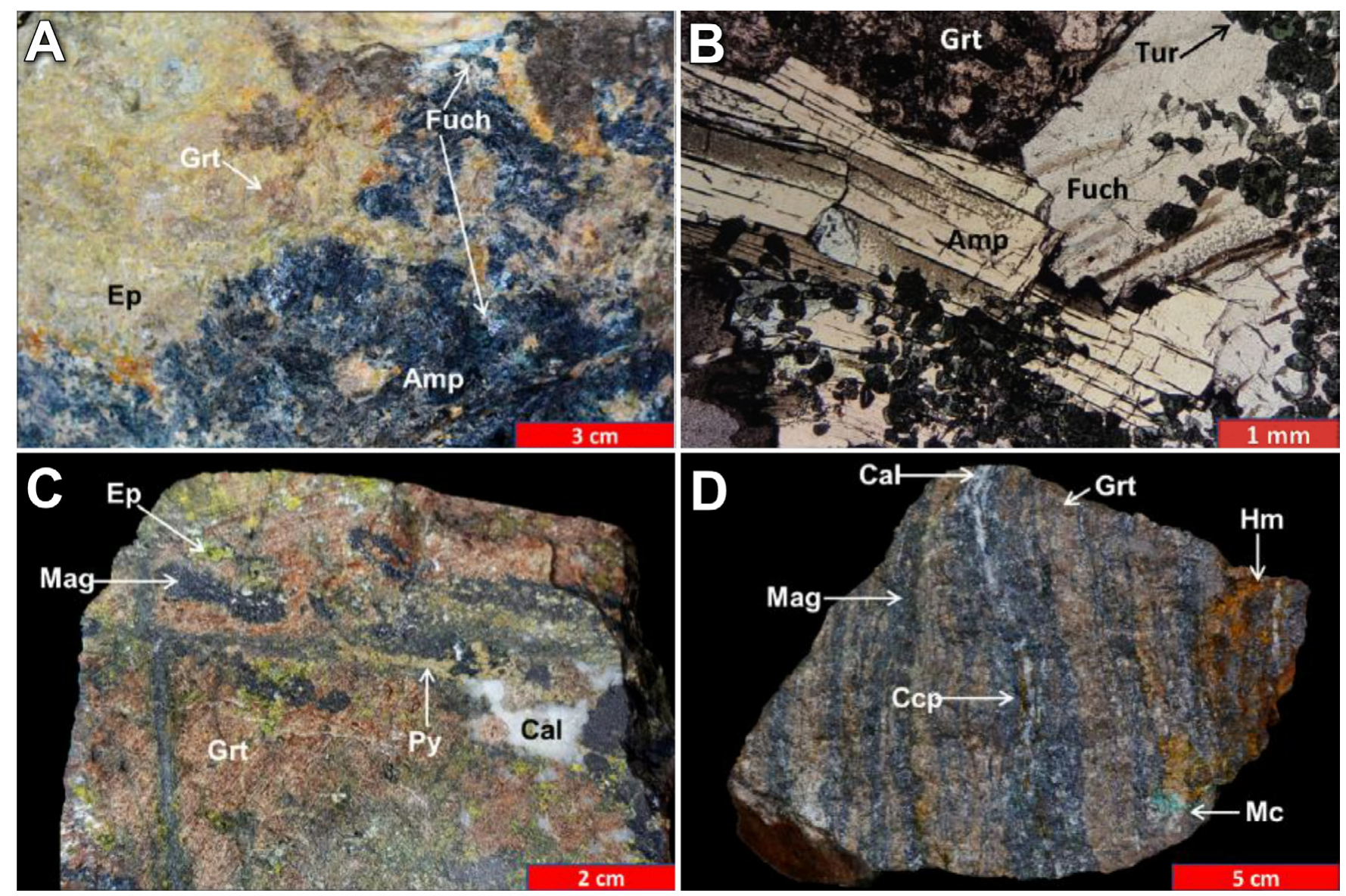

Figure 2 Selected aspects of the IOCG skarn mineralization at the Tatatila-Las Minas deposits showing both prograde (garnet and tourmaline) and retrograde (actinolite and fuchsite) associations. (A) Hand specimen showing a garnet-rich prograde association followed by an actinolite- and fuchsite-rich retrograde association in the Santa Cruz mine. (B) Photomicrography of a garnet and tourmaline prograde association followed by an actinolite and fuchsite retrograde association; transmitted light, crossed polars; same sample as in A. Fuchsite separates from A and B were dated by argon geochronometry in this study. (C) Hand specimen of prograde patchy to partially banded magnetite ore; El Dorado mine. (D) Hand specimen of banded exoskarn magnetite- and chalcopyrite-rich retrograde ore, with martitized magnetite; El Dorado mine. Key: Amp = amphibole-group minerals (actinolite), Cal = calcite, Ccp = chalcopyrite, Ep = epidote, Fuch = chromian muscovite or "fuchsite", Grt = garnet-group minerals (grossular-andradite), $\mathrm{Hm}=$ hematite, Mag = magnetite, Mc $=$ malachite, Py = pyrite, Tur $=$ tourmaline. 

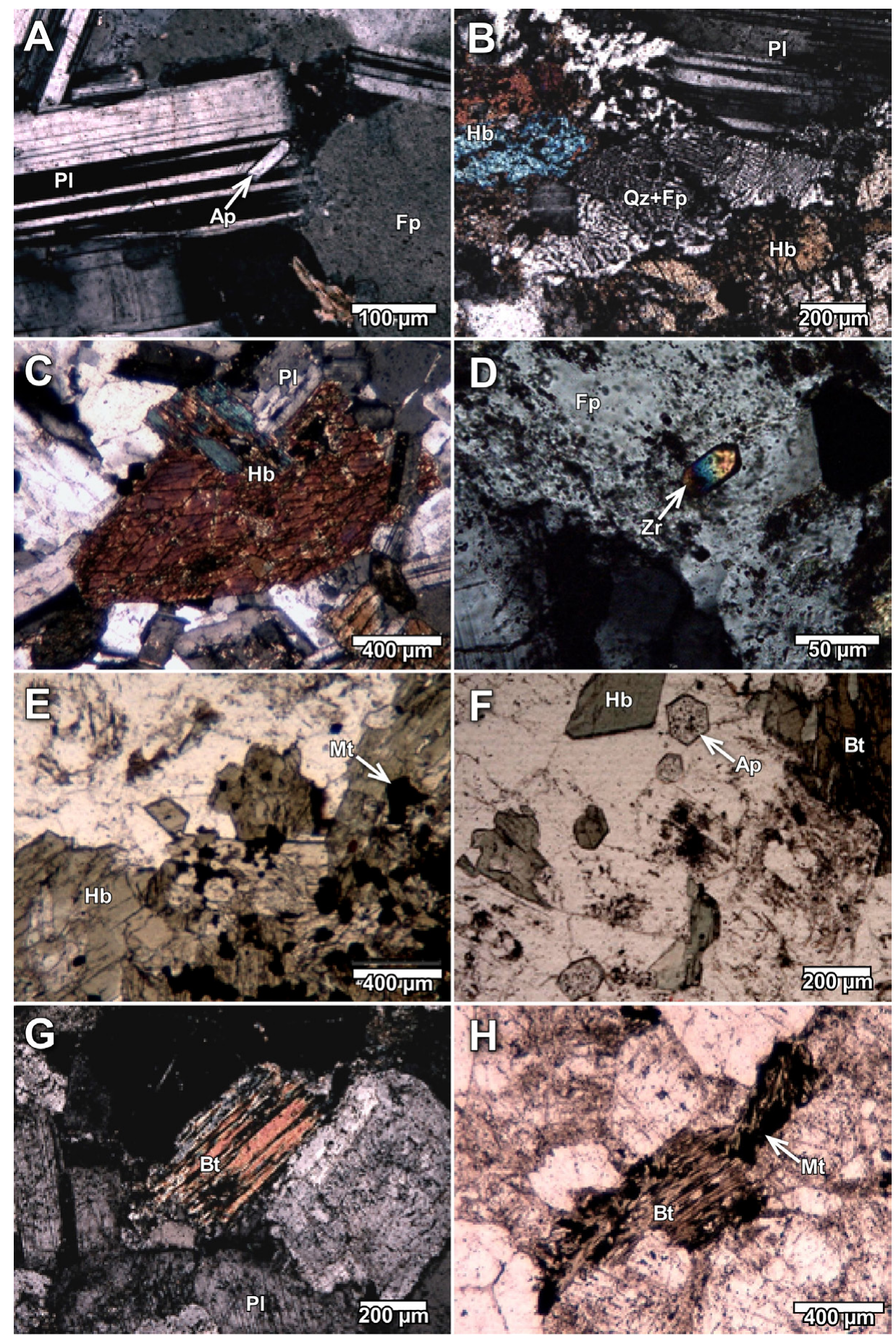

Figure 3 Photomicrographs of representative hypabyssal bodies, unaffected by hydrothermal alteration, associated with IOCG skarn mineralization in the Tatatila-Las Minas district. (A) Quartz-monzodiorite showing euhedral apatite crystals within plagioclase phenocrysts, Santa Cruz mine; transmitted light, crossed polars. (B) Quartz-monzodiorite showing myrmekitic intergrowths, surrounded by hornblende and plagioclase phenocrysts, La Virgen mine; transmitted light, crossed polars. (C) Quartz-monzodiorite showing hornblende phenocrysts, Santa Cruz mine; transmitted light, crossed polars. (D) Quartz-monzodiorite showing euhedral zircon crystals within potassium feldspar, Santa Cruz mine; transmitted light, crossed polars. (E) Monzodiorite showing hornblende intergrown with magnetite, Carbonera mine; planepolarized transmitted light. (F) Monzodiorite showing euhedral hornblende, biotite and apatite crystals within a plagioclase-potassium feldspar assemblage, Carbonera mine; plane-polarized transmitted light. (G) Monzogranite showing rock-forming biotite crystals, same sample as in F, Rancho La Virgen; transmitted light, crossed polars. (H) Monzogranite showing late biotite crystals intergrown with magnetite, Rancho La Virgen; plane-polarized transmitted light. Key: $\mathrm{Ap}=$ apatite, $\mathrm{Bt}=$ biotite, $\mathrm{Fp}=$ potassium feldspar, $\mathrm{Hb}=$ hornblende, $\mathrm{Mt}=\mathrm{magnetite}$, $\mathrm{PI}=$ plagioclase, $\mathrm{Qz}=$ quartz, $\mathrm{Zr}=$ zircon. 
Mining activity in the study area can be dated back to pre-colonial epochs, when the native population of Chiconquiaco obtained gold that was mainly destined to fulfill the contributions imposed upon them by their Aztec overlords. Formal mining by the Spaniards can be dated back to at least 1680, when the exploitation of large high-grade gold and silver bonazas has been documented (Castro-Mora et al., 1994). Mining and exploration have remained intermittently active in the area ever since (Viniegra, 1965; Castro-Mora et al., 1994; Servicio Geológico Mexicano, 2007). By 1996, the exploration endeavors carried out by International Northair, in association with Battle Mountain Gold Co., allowed location of relevant $\mathrm{Au}-\mathrm{Cu}-\mathrm{Fe}$ resources in a broad area. In 2006, Bell Resources Corp. took over the property in the Las Minas area and subsequently assigned the mining rights to Chesapeake Gold Corp.

The formation of this $\mathrm{Au}-\mathrm{Cu}-\mathrm{Fe}$ rich area is generally acknowledged to belong to an IOCG model with overimposed late epithermal veins (Servicio Geológico Mexicano, 2007; Camprubí, 2009, 2013; Dorantes-Castro, 2016; Castro-Mora et al., 2016; Sarabia-Jacinto, 2017). The metal grades in the deposit range between 1 and 39.3 ppm Au, between 4.11 and $127 \mathrm{ppm} \mathrm{Ag}$, and between 0.64 and $11.7 \% \mathrm{Cu}$; inferred reserves are $719000 \mathrm{Oz} \mathrm{Au}$ equiv., and indicated reserves are $304000 \mathrm{Oz}$ Au equiv. (Castro-Mora et al., 2016).

\section{Methodology}

Representative samples from the Neogene intrusive ensemble were collected in the Tatatila-Las Minas mineralized area (47 samples; purple circles in Figure 1) in order to characterize the petrologic affinity and age of skarn-generating intrusive bodies, as well as the age of hydrothermal activity itself. The ages of intrusions are considered as representative of the age of prograde mineralization in IOCG skarns, and hydrothermal assemblages correspond to retrograde stages of these deposits. The representativeness of such samples with regard to the formation (or postdating) of min- eralized bodies was determined on the basis of their distribution, their possible association with mineralized bodies, and the types of rocks thereby represented, after thorough cartography and sampling. All the analyzed samples were examined by means of petrographic studies in order to ensure that no alteration would cause any disturbances to the geochemical or geochronological analyses.

Elemental analyses were carried out on $15 \mathrm{~g}$ aliquots from samples at a 200 mesh. The two dated samples from retrograde hydrothermal associations are chromian muscovite, which correspond to high-temperature phyllic assemblages from the Las Minas area, and zircon within pervasive potassic alteration assemblages from the Tatatila area.

Multi-elemental geochemical analyses of host rocks were carried out by means of X-ray fluorescence (XRF) with a Rigaku Primus II equipment available at the Laboratorio Nacional de Geoquímica y Mineralogía (LANGEM) in accordance with the procedure described by Lozano-Santa Cruz et al. (1995); results are presented in Table 1. Trace and rare-earth elements (REE) were analyzed by means of inductively coupled plasma quadrupole mass spectrometery (Q-ICP-MS) with a Termo ICap Qc equipment, coupled to a collision/reaction cell $\left(\mathrm{He}, \mathrm{N}_{2}, \mathrm{NH}_{3}\right.$ and $\left.\mathrm{O}_{2}\right)$ in order to minimize spectral interference, the procedure described by Mori et al. (2007), at the Laboratorio de Estudios Isotópicos (LEI) of the Centro de Geociencias (CGeo-UNAM). The obtained data are presented in Table 2. For $\mathrm{Sr}, \mathrm{Nd}$ and $\mathrm{Pb}$ isotopic analyses, a Thermo Fisher Neptune Plus mass spectrometer available at the CGeo-UNAM. Sample preparation and measurement procedures for $\mathrm{Sr}-\mathrm{Nd}-\mathrm{Pb}$ isotopic analyses are described in Gómez-Tuena et al. (2003) for LDEO. ${ }^{87} \mathrm{Sr} /{ }^{86} \mathrm{Sr}$ ratios obtained in both labs were normalized to ${ }^{86} \mathrm{Sr} /{ }^{88} \mathrm{Sr}=0.1194$ and corrected to a NBS-987 standard ratio of ${ }^{87} \mathrm{Sr} /{ }^{86} \mathrm{Sr}=0.710230$, and ${ }^{143} \mathrm{Nd} /{ }^{144} \mathrm{Nd}$ ratios were normalized to ${ }^{146} \mathrm{Nd} /{ }^{144} \mathrm{Nd}$ $=0.72190$ and corrected to a La Jolla standard value of ${ }^{143} \mathrm{Nd} /{ }^{144} \mathrm{Nd}=0.511860$. At $\mathrm{LDEO}, \mathrm{Sr}$ and $\mathrm{Nd}$ were measured by dynamic multicollection, with each analysis consisting of $\sim 120$ isotopic 
Table 1. Major elements in host intrusive rocks to the Tatatila-Las Minas IOCG deposits. All values in wt.\%. Asterisks (*) correspond to analyses in Dorantes-Castro (2016).

\begin{tabular}{|c|c|c|c|c|c|c|c|c|c|c|c|c|c|c|c|}
\hline & \multicolumn{2}{|c|}{ UTM coordinates } & Rock & $\mathrm{SiO}_{2}$ & $\mathrm{TiO}_{2}$ & $\mathrm{Al}_{2} \mathrm{O}_{3}$ & $\mathrm{Fe}_{2} \mathrm{O}_{3}(\mathrm{t})$ & MnO & $\mathrm{MgO}$ & $\mathrm{CaO}$ & $\mathrm{Na}_{2} \mathrm{O}$ & $\mathrm{K}_{2} \mathrm{O}$ & $\mathrm{P}_{2} \mathrm{O}_{5}$ & LOI & Total \\
\hline & $\mathbf{E}$ & $\mathbf{N}$ & & & & & & & & & & & & & \\
\hline TMG-1 & 699173 & 2176551 & Gabbro & 43.89 & 0.81 & 17.94 & 13.66 & 0.22 & 8.92 & 13.02 & 1.30 & 0.19 & 0.04 & 1.12 & 99.60 \\
\hline TMG-2 & 698856 & 2176474 & Diorite & 61.33 & 0.75 & 17.09 & 5.32 & 0.07 & 2.31 & 4.78 & 3.95 & 4.20 & 0.20 & 0.75 & 99.58 \\
\hline TMG-3 & 698516 & 2176325 & $\begin{array}{c}\text { Quartz } \\
\text { monzodiorite }\end{array}$ & 62.14 & 0.71 & 17.06 & 5.41 & 0.07 & 2.49 & 4.53 & 4.10 & 3.30 & 0.19 & 1.79 & 99.56 \\
\hline TMG-4 & 697820 & 2176599 & $\begin{array}{c}\text { Quartz } \\
\text { monzodiorite }\end{array}$ & 58.22 & 0.78 & 17.87 & 6.81 & 0.11 & 3.23 & 5.85 & 3.93 & 2.96 & 0.23 & 0.71 & 99.60 \\
\hline TMG-5 & 697764 & 2176999 & Monzodiorite & 58.63 & 0.85 & 17.35 & 6.81 & 0.12 & 3.03 & 5.72 & 3.97 & 3.28 & 0.23 & 0.68 & 99.60 \\
\hline TMG-6 & 696871 & 2177577 & $\begin{array}{c}\text { Quartz } \\
\text { monzodiorite }\end{array}$ & 61.78 & 0.71 & 17.05 & 5.46 & 0.10 & 2.39 & 4.32 & 3.82 & 4.19 & 0.19 & 0.49 & 99.60 \\
\hline TMG-7 & 692733 & 2179299 & Quartz diorite & 59.29 & 0.60 & 16.53 & 6.15 & 0.13 & 4.40 & 7.10 & 3.68 & 1.92 & 0.19 & 0.71 & 99.58 \\
\hline TMG-8 & 692919 & 2179241 & Diorite & 48.99 & 0.73 & 15.64 & 9.98 & 0.17 & 9.21 & 12.27 & 2.24 & 0.64 & 0.13 & 1.17 & 99.60 \\
\hline TMG-9 & 692782 & 2178838 & Diorite & 52.39 & 0.85 & 19.26 & 9.48 & 0.15 & 4.07 & 8.50 & 3.93 & 1.02 & 0.35 & 0.95 & 99.50 \\
\hline TMG-10 & 701856 & 2183672 & Diorite & 55.09 & 1.47 & 17.04 & 7.86 & 0.14 & 3.87 & 7.57 & 4.13 & 2.42 & 0.41 & 0.19 & 99.50 \\
\hline TMG-11 & 701275 & 2182995 & Monzodiorite & 62.15 & 0.90 & 16.83 & 5.13 & 0.10 & 2.42 & 4.02 & 4.60 & 3.58 & 0.27 & 0.54 & 99.28 \\
\hline TMG-12 & 701201 & 2183034 & Monzonite & 63.44 & 0.88 & 16.16 & 4.60 & 0.11 & 2.03 & 3.50 & 4.51 & 4.55 & 0.22 & 0.03 & 99.59 \\
\hline TMG-13 & 700794 & 2183290 & Quartz diorite & 59.34 & 1.00 & 15.69 & 6.09 & 0.17 & 5.08 & 4.72 & 3.76 & 3.82 & 0.35 & 2.31 & 99.58 \\
\hline TMG-14 & 699639 & 2181985 & Monzonite & 55.79 & 1.05 & 14.15 & 5.82 & 0.10 & 4.60 & 10.97 & 3.47 & 3.46 & 0.60 & 0.46 & 99.55 \\
\hline TMG-15 & 699490 & 2180296 & Sienite & 59.34 & 0.61 & 20.94 & 4.23 & 0.05 & 1.69 & 4.52 & 4.92 & 3.36 & 0.33 & 1.29 & 99.60 \\
\hline TMG-16 & 698062 & 2181248 & Quartz monzonite & 55.76 & 1.18 & 17.36 & 8.87 & 0.17 & 4.14 & 7.11 & 3.10 & 2.00 & 0.31 & 0.04 & 99.58 \\
\hline TMG-17 & 698283 & 2181931 & Monzodiorite & 57.89 & 1.16 & 17.38 & 6.62 & 0.12 & 3.51 & 6.11 & 4.12 & 2.75 & 0.34 & 0.67 & 99.55 \\
\hline TMG-18 & 698504 & 2182345 & Monzogranite & 71.60 & 0.25 & 15.89 & 1.13 & 0.02 & 0.36 & 1.95 & 3.64 & 5.09 & 0.07 & 0.72 & 99.60 \\
\hline TMG-19 & 694715 & 2179684 & Diorite & 63.04 & 0.82 & 16.39 & 4.86 & 0.11 & 2.26 & 4.67 & 4.22 & 3.39 & 0.23 & 0.75 & 99.59 \\
\hline TMG-20 & 696828 & 2180239 & Quartz monzonite & 63.02 & 0.52 & 18.26 & 4.66 & 0.07 & 1.74 & 5.24 & 4.71 & 1.51 & 0.27 & 0.79 & 99.61 \\
\hline TMG-21 & 696325 & 2179917 & Diorite & 52.79 & 1.47 & 19.06 & 8.42 & 0.15 & 3.73 & 7.90 & 4.27 & 1.80 & 0.42 & 1.41 & 99.62 \\
\hline TMG-22 & 695717 & 2179384 & Granite & 77.60 & 0.09 & 14.83 & 0.42 & 0.00 & 0.31 & 1.02 & 2.78 & 2.91 & 0.04 & 1.63 & 99.61 \\
\hline TMG-23 & 694397 & 2177628 & Diorite & 60.88 & 0.54 & 15.82 & 6.07 & 0.13 & 4.41 & 6.16 & 3.97 & 1.88 & 0.13 & 0.95 & 99.59 \\
\hline TMG-24 & 694207 & 2177867 & Quartz diorite & 55.59 & 0.79 & 19.02 & 7.76 & 0.14 & 3.14 & 8.17 & 3.75 & 1.39 & 0.25 & 0.47 & 99.59 \\
\hline TMG-26 & 692818 & 2176784 & Diorite & 58.33 & 0.92 & 18.96 & 6.01 & 0.10 & 2.40 & 6.50 & 4.17 & 2.23 & 0.38 & 0.52 & 99.58 \\
\hline TMG-23 B & 694397 & 2177628 & Diorite & 52.36 & 1.37 & 18.46 & 7.94 & 0.14 & 3.93 & 6.67 & 4.34 & 1.63 & 0.39 & 2.38 & 99.61 \\
\hline TMG-1 2a & 699173 & 2176551 & Gabbro & 43.27 & 0.79 & 17.69 & 13.34 & 0.21 & 8.80 & 12.86 & 1.30 & 1.87 & 0.37 & 1.12 & 99.60 \\
\hline RV-2 & 694740 & 2179098 & Granodiorite & 66.55 & 0.44 & 17.38 & 2.95 & 0.03 & 0.89 & 4.22 & 4.88 & 1.83 & 0.16 & 0.57 & 99.90 \\
\hline RV-3 & 694688 & 2179102 & Gabbro & 47.00 & 0.95 & 15.66 & 10.86 & 0.14 & 10.61 & 9.47 & 1.89 & 2.35 & 0.20 & 0.84 & 99.97 \\
\hline BQ-1 & 694445 & 2178202 & Granite & 65.36 & 0.48 & 17.94 & 2.72 & 0.03 & 1.06 & 4.01 & 5.01 & 2.06 & 0.17 & 1.04 & 99.86 \\
\hline CR-1 & 6946662 & 2179718 & Gabbro-diorite & 52.00 & 0.85 & 16.65 & 8.79 & 0.15 & 6.67 & 8.44 & 3.17 & 1.19 & 0.25 & 1.04 & 99.96 \\
\hline SC-2 b 1 & 694317 & 2177448 & Diorite & 61.46 & 0.53 & 17.10 & 5.30 & 0.08 & 2.43 & 5.20 & 4.28 & 2.10 & 0.19 & 1.24 & 99.92 \\
\hline SC-2 b 2 & 694317 & 2177448 & Diorite & 61.78 & 0.52 & 16.79 & 5.12 & 0.09 & 2.32 & 5.30 & 4.17 & 2.25 & 0.19 & 0.19 & 99.91 \\
\hline SC-2 b 3 & 694317 & 2177448 & Diorite & 60.65 & 0.53 & 16.58 & 5.89 & 0.10 & 2.77 & 5.37 & 4.39 & 2.32 & 0.21 & 1.13 & 99.92 \\
\hline LS-6 & 696153 & 2179805 & Gabbro-diorite & 54.06 & 1.32 & 18.07 & 8.60 & 0.14 & 3.97 & 8.14 & 3.52 & 1.50 & 0.31 & 0.36 & 100.00 \\
\hline Es-3 & 698250 & 2181451 & Gabbro-diorite & 51.68 & 1.21 & 18.04 & 8.75 & 0.16 & 5.10 & 8.83 & 3.77 & 1.05 & 0.32 & 1.09 & 99.99 \\
\hline Ag-2 & 699636 & 2180877 & Monzodiorite & 59.70 & 0.76 & 16.78 & 6.43 & 0.09 & 2.94 & 5.34 & 3.72 & 3.45 & 0.22 & 0.58 & 99.99 \\
\hline LS-4 & 697074 & 2180612 & Granodiorite & 64.27 & 0.47 & 18.58 & 3.81 & 0.10 & 1.09 & 4.39 & 3.93 & 2.50 & 0.22 & 0.64 & 99.99 \\
\hline CR-6 & 693182 & 2179054 & Gabbro-diorite & 52.84 & 0.90 & 18.13 & 9.12 & 0.14 & 4.64 & 8.49 & 3.39 & 1.29 & 0.28 & 0.78 & 99.99 \\
\hline SC-3 & 694347 & 2177616 & Diorite & 57.52 & 0.76 & 18.06 & 7.40 & 0.12 & 2.55 & 7.43 & 3.61 & 1.60 & 0.26 & 0.70 & 99.99 \\
\hline$L V-1$ & 701870 & 2184419 & Monzodiorite & 56.29 & 1.15 & 18.15 & 7.23 & 0.13 & 3.29 & 6.70 & 4.03 & 2.31 & 0.35 & 0.15 & 100.00 \\
\hline CR-5 & 694325 & 2179704 & Gabbro-diorite & 53.49 & 0.92 & 17.21 & 8.28 & 0.15 & 4.73 & 8.12 & 3.48 & 1.97 & 0.24 & 1.42 & 100.00 \\
\hline LV-2 & 702091 & 2184527 & Monzodiorite & 56.67 & 1.16 & 17.64 & 7.38 & 0.13 & 3.38 & 6.76 & 3.80 & 2.55 & 0.34 & 0.19 & 100.00 \\
\hline LS-3 & 696389 & 2080049 & Monzodiorite & 56.88 & 1.09 & 18.09 & 7.37 & 0.13 & 2.94 & 6.33 & 3.76 & 2.39 & 0.34 & 0.68 & 100.00 \\
\hline Ag-5 & 699561 & 2181458 & Gabbro & 51.74 & 1.16 & 16.83 & 7.95 & 0.07 & 6.17 & 9.68 & 3.49 & 2.02 & 0.27 & 0.62 & 100.00 \\
\hline Es-2 & 698330 & 2181972 & Monzodiorite & 57.42 & 1.16 & 17.22 & 7.03 & 0.12 & 3.49 & 6.30 & 3.76 & 2.83 & 0.35 & 0.32 & 100.00 \\
\hline 1TJBQ* & & & Diorite & 58.74 & 0.38 & 16.96 & 6.61 & 0.14 & 2.81 & 8.09 & 5.08 & 0.38 & 0.15 & 0.61 & 99.22 \\
\hline 538* & & & Gabbro & 48.29 & 0.94 & 15.68 & 7.58 & 0.14 & 4.24 & 9.59 & 2.51 & 1.60 & 0.22 & 9.1 & 99.06 \\
\hline 33* & & & Monzodiorite & 54.57 & 1.14 & 16.14 & 6.59 & 0.14 & 5.21 & 9.57 & 3.72 & 2.13 & 0.34 & 0.34 & 99.17 \\
\hline 529* & & & Granodiorite & 66.94 & 0.42 & 16.95 & 2.60 & 0.029 & 1.22 & 3.89 & 4.66 & 2.00 & 0.17 & 0.96 & 99.55 \\
\hline
\end{tabular}

Key: LOI = loss on ignition. 


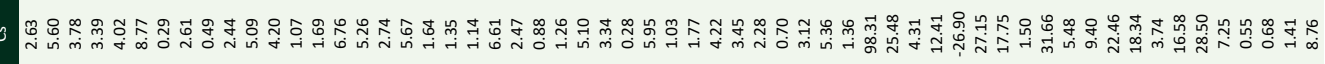

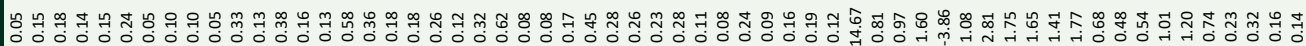

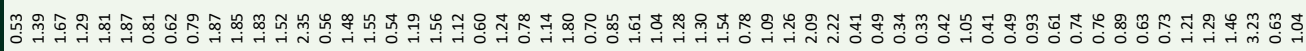

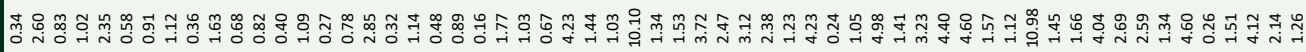

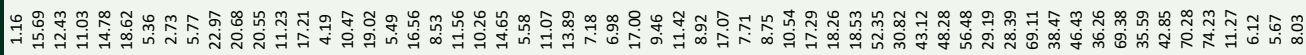

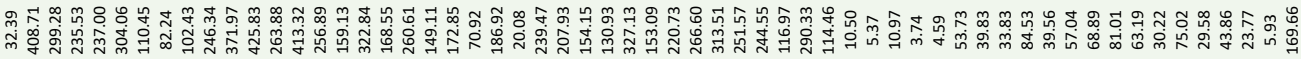

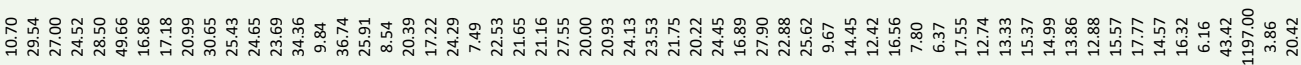

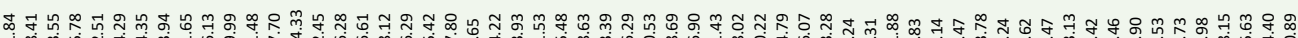

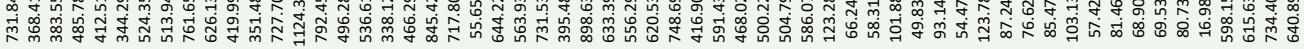

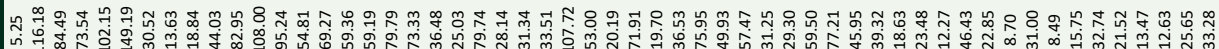

6

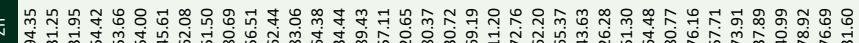

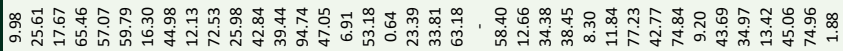

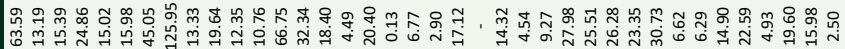

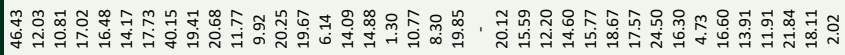

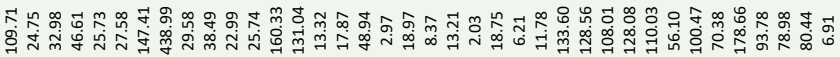

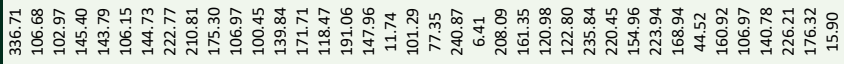

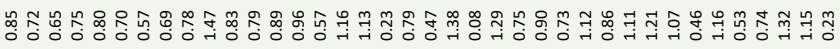

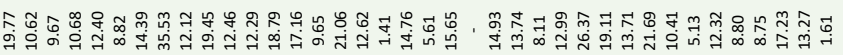

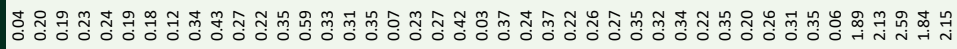

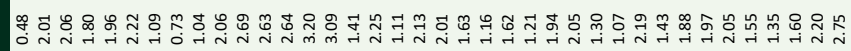

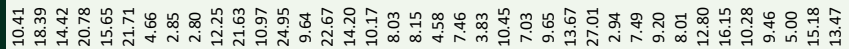




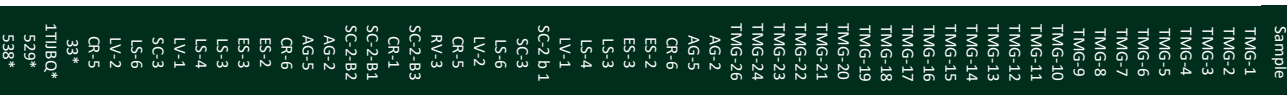

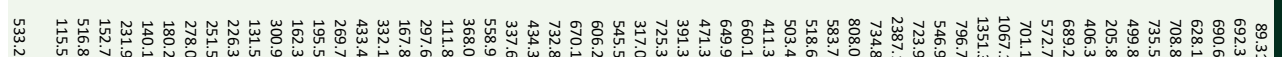

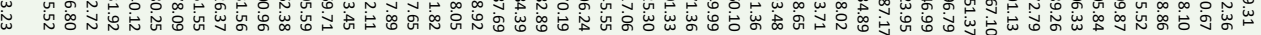

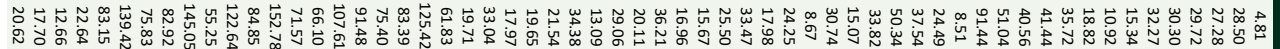

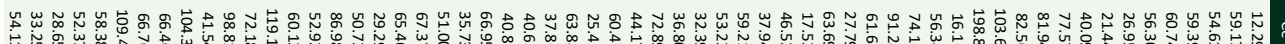

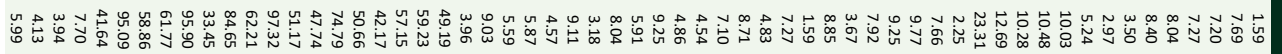

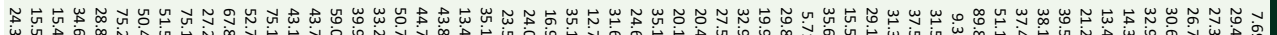

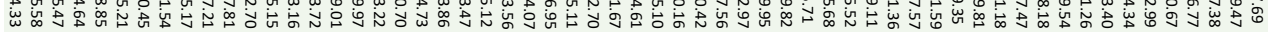

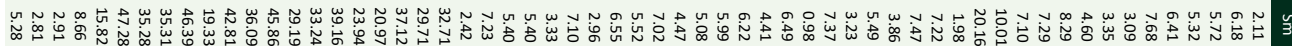

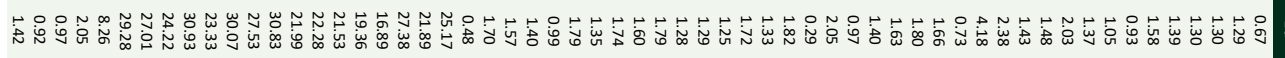

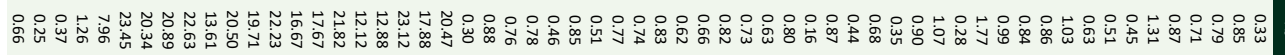

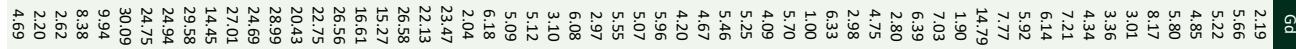

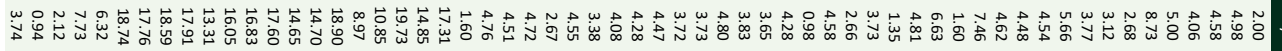

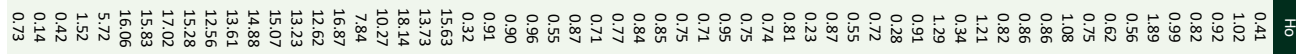

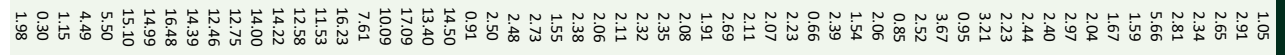

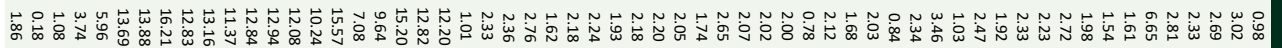

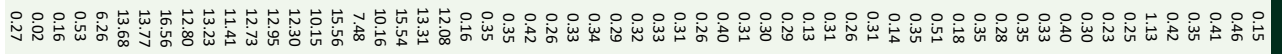

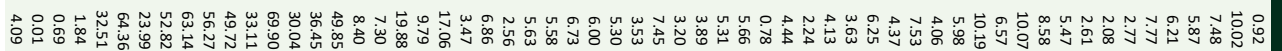

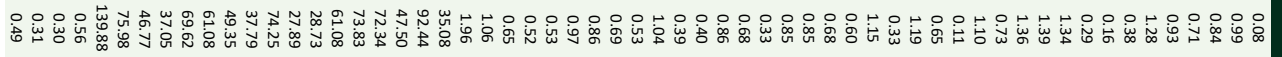

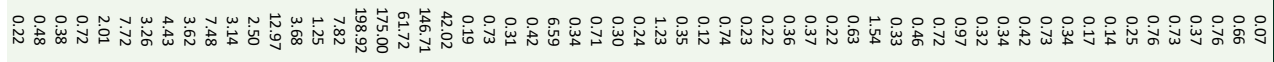

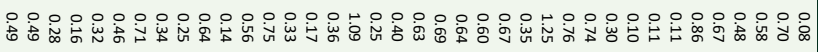

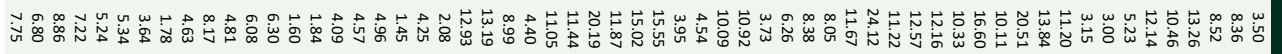

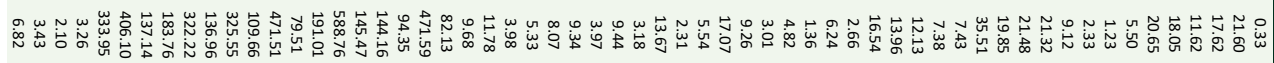

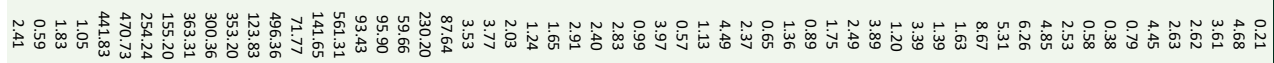

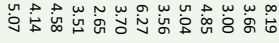


Table 3. $\mathrm{Sr}, \mathrm{Nd}$ and $\mathrm{Pb}$ isotopic values of selected samples from intrusive rocks associated with IOCG skarn mineralization in the Tatatila-Las Minas area

\begin{tabular}{|c|c|c|c|c|c|c|c|}
\hline Muestra & ${ }^{87} \mathbf{S r}{ }^{86} \mathbf{S r}$ & $\mathbf{8 S r}$ & ${ }^{143} \mathbf{N d} /{ }^{144} \mathbf{N d}$ & $\mathbf{8 N d}$ & ${ }^{206} \mathbf{P b} /{ }^{204} \mathbf{P b}$ & ${ }^{207} \mathbf{P b} /{ }^{\mathbf{2 0 4}} \mathbf{P b}$ & ${ }^{208} \mathbf{P b} /{ }^{\mathbf{2 0 4}} \mathbf{P b}$ \\
\hline SC-2 b1 & 0.7044 & -1.4 & 0.5127 & 1.2 & 18.75 & 15.6012 & 38.4921 \\
\hline SC-2 b2 & 0.7045 & 0 & 0.5127 & 1.2 & 18.70 & 15.6004 & 38.4490 \\
\hline SC-2 b3 & 0.7041 & -5.7 & 0.5127 & 1.2 & 18.73 & 15.5966 & 38.4887 \\
\hline BQ-1 & 0.7059 & 19.9 & 0.5123 & -6.6 & 18.68 & 15.6085 & 38.4041 \\
\hline RV-2 & 0.7059 & 19.9 & 0.5123 & -6.6 & 18.65 & 15.6062 & 38.4562 \\
\hline RV-3 & 0.7040 & -7.1 & 0.5128 & 3.2 & 18.69 & 15.5993 & 38.4149 \\
\hline CR-5 & 0.7042 & -4.3 & 0.5126 & -0.7 & 18.75 & 15.5994 & 38.4601 \\
\hline LV-2 & 0.7039 & -8.5 & 0.5128 & 3.2 & 18.74 & 15.5947 & 38.4433 \\
\hline Es-3 & 0.7042 & -4.3 & 0.5127 & 1.2 & 18.72 & 15.5982 & 38.5354 \\
\hline LS-3 & 0.7037 & -11.4 & 0.5128 & 3.2 & 18.67 & 15.5800 & 38.3878 \\
\hline LS-6 & 0.7040 & -7.1 & 0.5128 & 3.2 & 18.68 & 15.5928 & 38.4449 \\
\hline
\end{tabular}

ratios. Sr ratios were measured using tungsten filaments and $\mathrm{a} \mathrm{TaCl}_{4}$ activator solution (Birck, 1986). $\mathrm{Nd}$ isotopes were measured as $\mathrm{NdO}+$. During five separate analysis intervals the measured values of the NBS-987 standard were ${ }^{87} \mathrm{Sr} /{ }^{86} \mathrm{Sr}=0.710245$ $\pm 0.000016(2 \sigma, \mathrm{n}=4) ; 0.710271 \pm 0.000014(2 \sigma$, $\mathrm{n}=6) ; 0.710274 \pm 0.000016(2 \sigma, \mathrm{n}=18) ; 0.710310$ $\pm 0.000013(2 \sigma, \mathrm{n}=5) ; 0.710261 \pm 0.000012(2 \sigma$, $\mathrm{n}=10)$. The measured ${ }^{143} \mathrm{Nd} /{ }^{144} \mathrm{Nd}$ ratio of the $\mathrm{La}$ Jolla standard at LDEO was $0.511836 \pm 0.000013$ $(2 \sigma, \mathrm{n}=15)$, as of Todt et al. (1996), according to the procedure described by Mori et al. (2007), obtained data are presented in Table 3 .

The two dated samples from retrograde hydrothermal associations are chromian muscovite that corresponds to high-temperature phyllic assemblages from the Las Minas area, and zircon within pervasive potassic alteration assemblages from the Tatatila area, the ${ }^{40} \mathrm{Ar} /{ }^{39} \mathrm{Ar}$ analyses of samples from intrusive rocks were carried out at the Noble Gas Laboratory, Pacific Centre for Isotopic and Geochemical Research, University of British Columbia (Vancouver, British Columbia, Canada). The mineral separates were step-heated at incrementally higher powers in the defocused beam of a $10 \mathrm{~W} \mathrm{CO}_{2}$ laser (New Wave Research MIR 10) until fused. The gas evolved from each step was analyzed by a VG5400 mass spectrometer equipped with an ion-counting electron multiplier. All measurements were corrected for total system blank, mass spectrometer sensitivity, mass discrimination, radioactive decay during and subsequent to irradiation, as well as interfering Ar from atmospheric contamination and the irradiation interferences of $\mathrm{Ca}, \mathrm{Cl}$ and $\mathrm{K}$. The plateau and correlation ages were calculated using the Isoplot 3.09 software (Ludwig, 2003). Errors are quoted at the 2 -sigma (95\% confidence) level and are propagated from all sources except mass spectrometer sensitivity and age of the flux monitor. The full results and spectra are reported in Appendices 1 and 2 and summarized in Figure 4.

The ${ }^{40} \mathrm{Ar} /{ }^{39} \mathrm{Ar}$ analysis were performed at the Geochronology Laboratory of the Departmento de Geología, Centro de Investigación Científica y Educación Superior de Ensenada (CICESE, Mexico). The argon isotope experiments were conducted on a few flakes of fuchsite, hornblende, $\mathrm{K}$-feldspar and biotite. The mineral grains were heated with a Coherent Ar-ion Innova 370 laser. The extraction system is on line with a VG5400 mass spectrometer. The sample and irradiation monitors, were irradiated in the Uenriched research reactor of University of McMaster in Hamilton, Canada, at position 5C. To block thermal neutrons, the capsule was covered with a cadmium liner during irradiation of chromian muscovite ("fuchsite"; Figure 5A and 5B) from the skarn gangue association in IOCG mantos, Santa Cruz mine (sample SC-1). The mineral grains were heated with a Coherent Ar ion Innova 370 laser. The extraction system is on line with a VG5400 mass spectrometer. The sample and irradiation monitors were irradiated 
in the U-enriched research reactor of University of McMaster in Hamilton, Canada, at position 5C. To block thermal neutrons, the capsule was covered with a cadmium liner during irradiation. To determine the neutron flux variations, aliquots of the irradiation monitor FCT-2 sanidine (28.201 $\pm 0.046 \mathrm{Ma}$; Kuiper et al., 2008) were irradiated alongside sample SG-1. Upon irradiation the monitors were fused in one step while the fuchsite sample was step-heated. The argon isotopes were corrected for blank, mass discrimination, radioactive decay of ${ }^{37} \mathrm{Ar}$ and ${ }^{39} \mathrm{Ar}$, and atmospheric contamination. For the $\mathrm{Ca}$ neutron interference reactions, the factors given by Masliwec (1984) were used. The decay constants recommended by Steiger and Jäger (1977) were applied in the data processing. The equations reported by York et al. (2004) were used in all the straight line fitting routines of the argon data reduction. ${ }^{40} \mathrm{Ar} /{ }^{39} \mathrm{Ar}$ data are presented in Appendices 1 and 2, which includes the results of the individual steps, and the integrated, plateau and isochron ages, and their synthetic version in Figure 5. The analytical precision is reported as standard deviation $(2 \sigma)$. The error in the integrated, plateau and isochron ages includes the scatter in the irradiation monitors. With the exception of the first fraction, a well-defined straight line, with mean squared weighted deviations (MSWD) of 0.55 for $\mathrm{n}=6$, indicates an isochron age of $12.49 \pm 0.09 \mathrm{Ma}$.

Zircon crystals were separated by means of panning from samples selected for $\mathrm{U}-\mathrm{Pb}$ dating that are representative of various sets of rocks in the area: $\mathrm{Au}-\mathrm{Ag}$ mineralized vein from Tatatila (sample TMG-5), and granodiorite to granite samples from the Santa Cruz (samples TMG-24 and SC-2), Carboneras (CR-5), Escalona (ES3), Cinco Señores (5S-1), Boquillas (BQ-1), and Rancho Virgen (RV-2) areas. The sizes of the collected zircon crystals range between 20 and

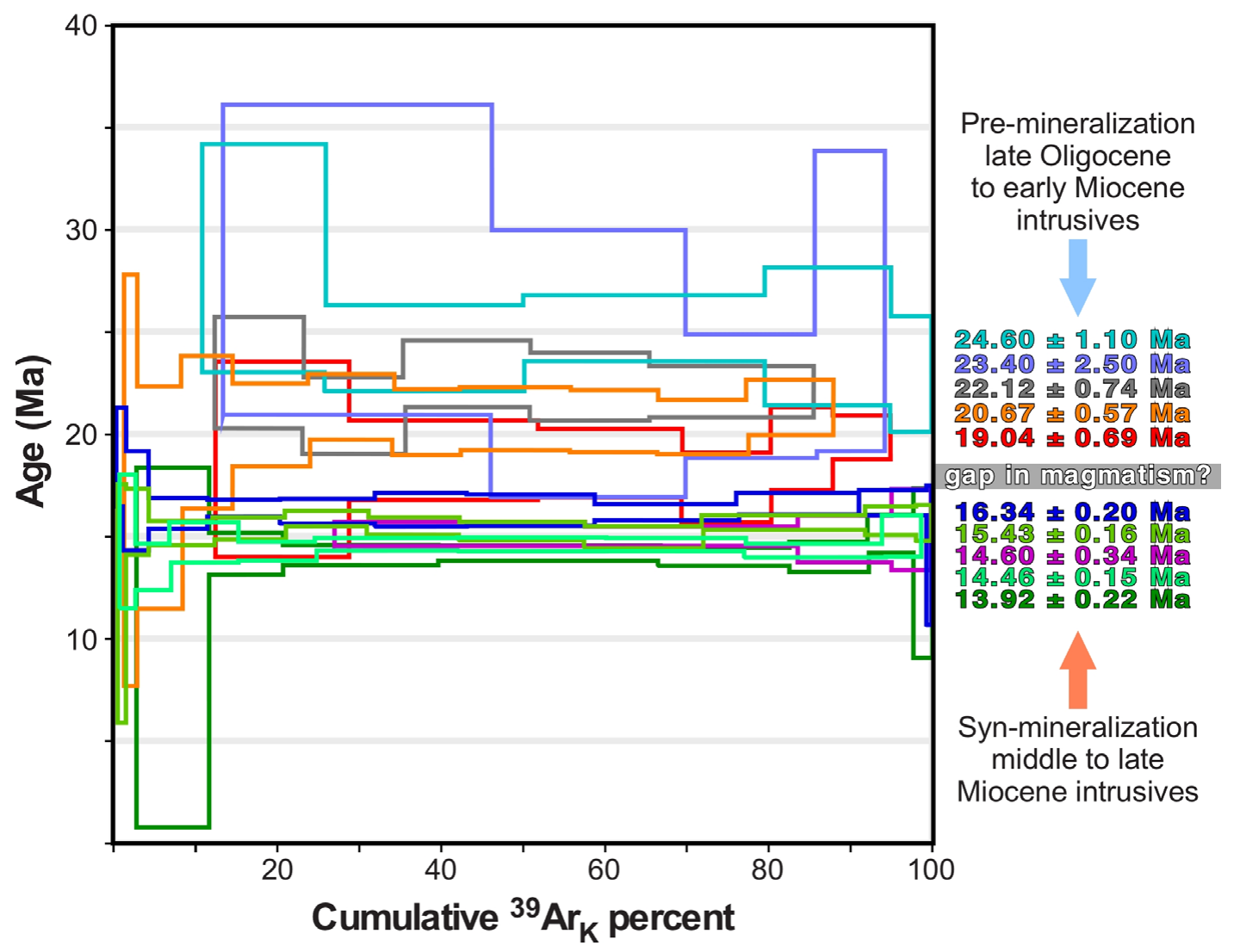

Figure 4 Outlines of ${ }^{40} \mathrm{Ar} /{ }^{39} \mathrm{Ar}$ age spectra (plateau ages) of intrusive host rocks to the IOCG skarn deposits in the Tatatila-Las Minas district, Veracruz. 

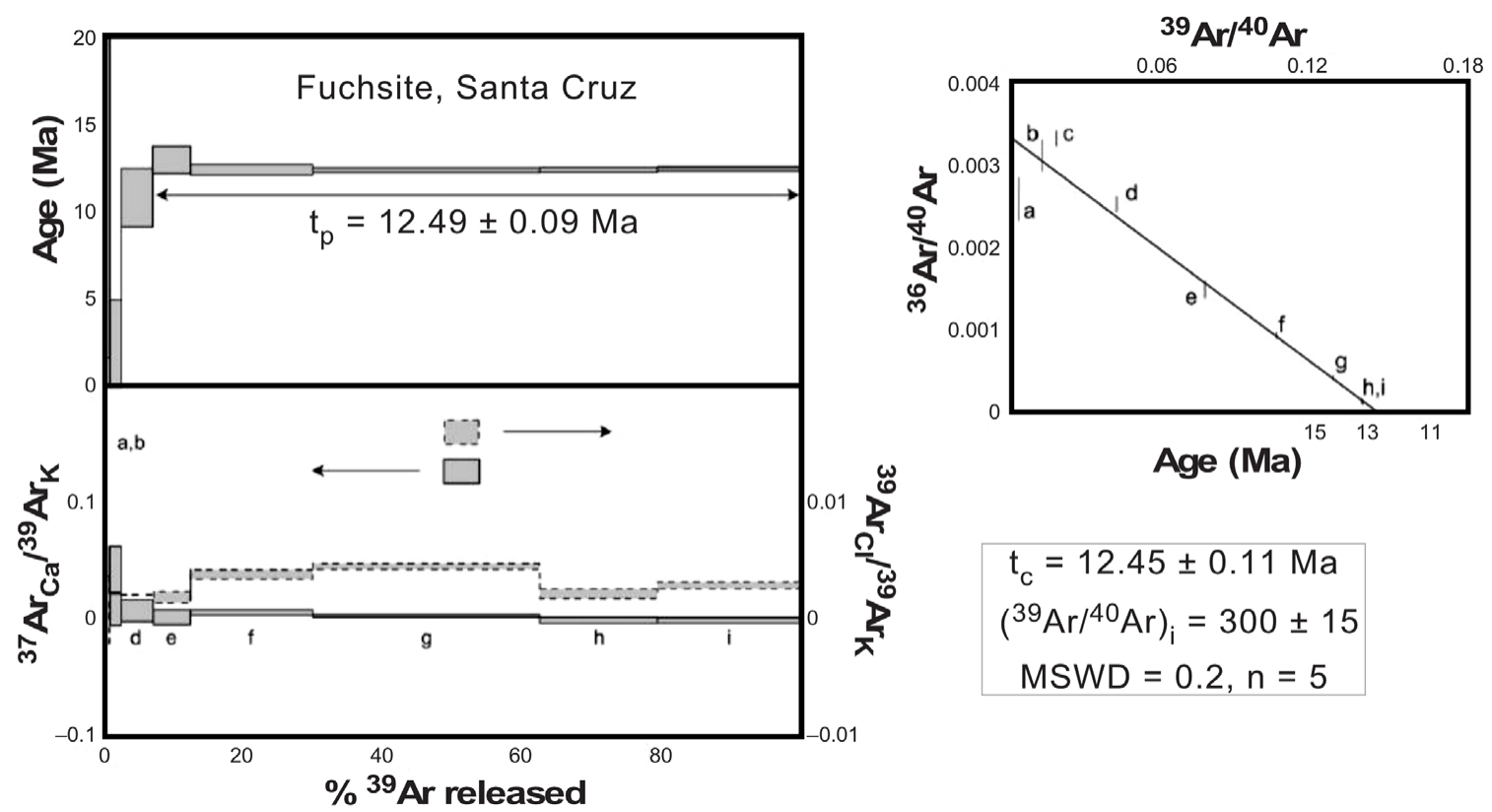

$\mathrm{t}_{\mathrm{c}}=12.45 \pm 0.11 \mathrm{Ma}$

$\left({ }^{39} \mathrm{Ar} /{ }^{40} \mathrm{Ar}\right)_{\mathrm{i}}=300 \pm 15$

MSWD $=0.2, n=5$

Figure $5{ }^{40} \mathrm{Ar} /{ }^{39} \mathrm{Ar}$ age spectra (plateau and isochron ages) of a chromian muscovite ("fuchsite") from the magmatic-hydrothermal retrograde assemblage of the IOCG skarn deposit in the Santa Cruz mine, Tatatila-Las Minas district, Veracruz.

$90 \mu \mathrm{m}$ in length. The $\mathrm{U}-\mathrm{Pb}$ zircon analyses were performed with a quadrupole Thermo-X series ICP-MS with an Excimer (193 nm) laser ablation system by Resonetics, at the Isotopic Studies Laboratory (LEI), CGeo-UNAM, and following the procedure described by Solari et al. (2010). The data reduction was performed with the aid of the UPb.age in-house software (Solari and Tanner, 2011) and plotted with the Isoplot 3.0 software (Ludwig, 2003). See further technical aspects in González-León et al. (2017). U-Pb ages are displayed in Figures 6 and 7, Table 4 and Appendix 3.

\section{Results}

The U-Pb ages of zircon crystals from granite, granodiorite, quartz-monzonite and monzodiorite are displayed in Figures 6 and 7, in Table 4, and Appendices 3 and 4. The sample from Carboneras (CR-5) yielded a U-Pb concordia lower intercept at $15.05 \pm 0.94 \mathrm{Ma}(\mathrm{MSWD}=2.5, \mathrm{n}=19$; Figure 7C). Two samples from the Santa Cruz mine were dated; sample TMG-24 yielded a U-Pb concordant age at $15.27 \pm 0.36 \mathrm{Ma}(\mathrm{MSWD}=2 \mathrm{n}=14$;
Figure $6 \mathrm{~A})$, and sample SC-2b a weighted mean $\mathrm{U}-\mathrm{Pb}$ age at $14.33 \pm 0.38 \mathrm{Ma}(\mathrm{MSWD}=2.6, \mathrm{n}$ = 9; Figure 7B). The sample from Cinco Señores (5S-1) yielded a $\mathrm{U}-\mathrm{Pb}$ weighted mean age at 15.09 $\pm 0.48 \mathrm{Ma}(\mathrm{MSWD}=4.0, \mathrm{n}=8$; Figure 7D). ${ }^{40} \mathrm{Ar} /{ }^{39} \mathrm{Ar}$ determinations in host intrusive samples as granodiorite, granite, monzodiorite and quartz-monzonite yielded two groups of ages: (A) late Oligocene to early Miocene, between $22.12 \pm$ 0.74 and $19.04 \pm 0.69 \mathrm{Ma}$ for a pre-mineralization suite of intrusive bodies, and (B) middle to late Miocene, between $16.34 \pm 0.20$ and $13.92 \pm 0.22$ Ma for a syn-mineralization suite of intrusive bodies, all reported ages correspond to plateau ages.

The samples for ${ }^{40} \mathrm{Ar} /{ }^{39} \mathrm{Ar}$ different minerals such as biotite, hornblende, K-feldspar and fuchsite, were separated from each sample for analysis.

The ${ }^{40} \mathrm{Ar} /{ }^{39} \mathrm{Ar}$ determination in hydrothermal chromian muscovite ("fuchsite") of the Santa Cruz mine yielded a plateau age of $12.49 \pm 0.09$ Ma (isochron age at $12.39 \pm 0.1 \mathrm{Ma}$; Figure 5). The sample (TMG-5) from a potassic alteration assemblage that was pervasively developed on a granite-granodiorite intrusion in the village of Tatatila (thus corresponding to hydrothermal 

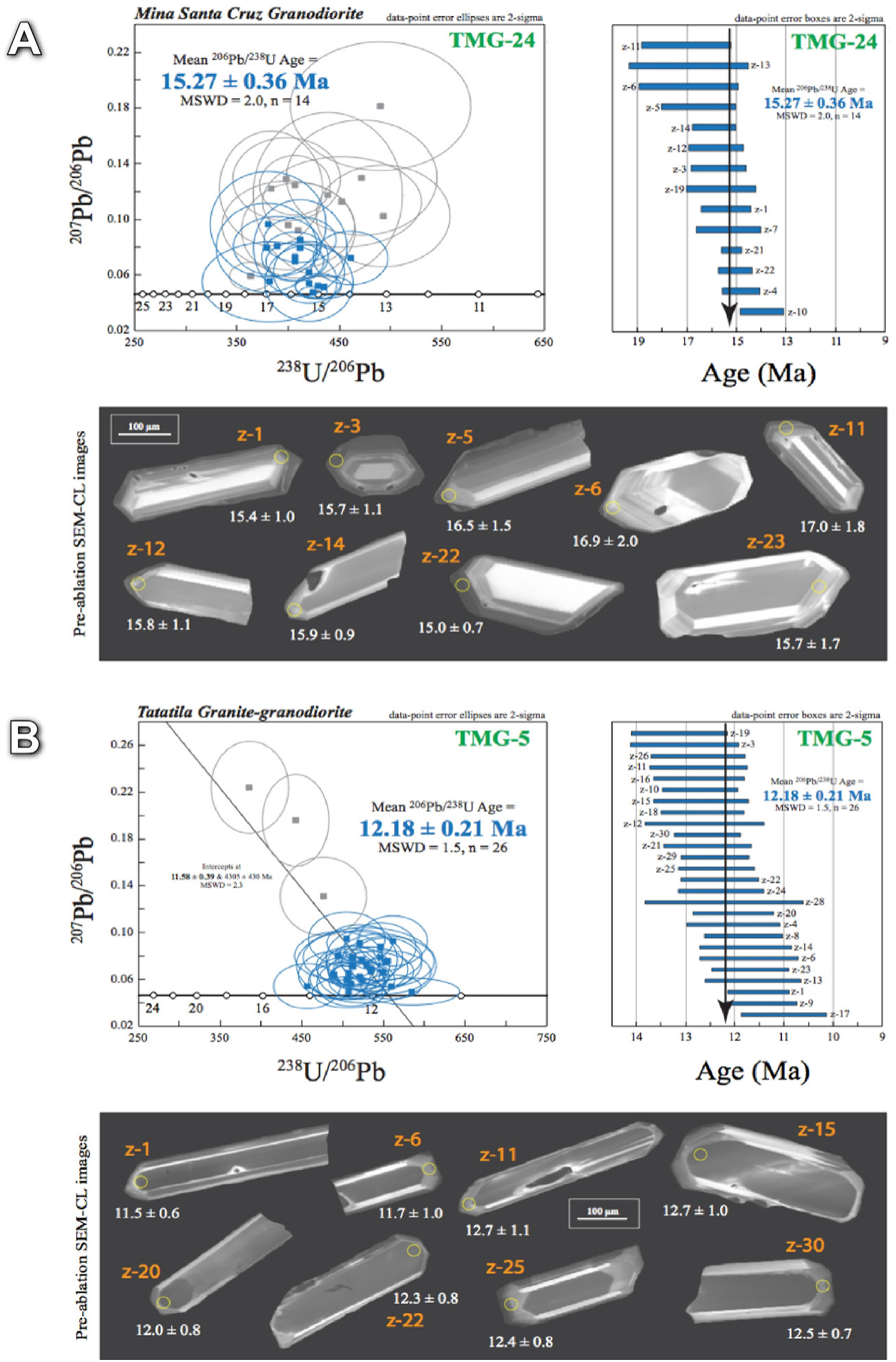

Figure 6 Tera-Wasserburg U-Pb concordia diagrams and plots of weighted averages of individual ${ }^{206} \mathrm{~Pb} /{ }^{238} \mathrm{U}$ ages of analyzed zircons, and pre-ablation SEM-CL images of zircons from a granodiorite intrusive from the Santa Cruz Mine (A), and from a potassic alteration assemblage that was pervasively developed on a granite-granodiorite intrusion in the village of Tatatila (B), from the Tatatila-Las Minas district, Veracruz. Solid-line ellipses, with blue square centers, are data used for age calculations; gray-line ellipses are data excluded from age calculations due to different degrees of $\mathrm{Pb}$-loss and/or zircon inheritance. All U-Pb data are plotted with 2-sigma errors and all calculated weighted mean ages are also listed at the 2-sigma level. Original $\mathrm{U}(\mathrm{Th})-\mathrm{Pb}$ data can be found for inspection in Table 5. 

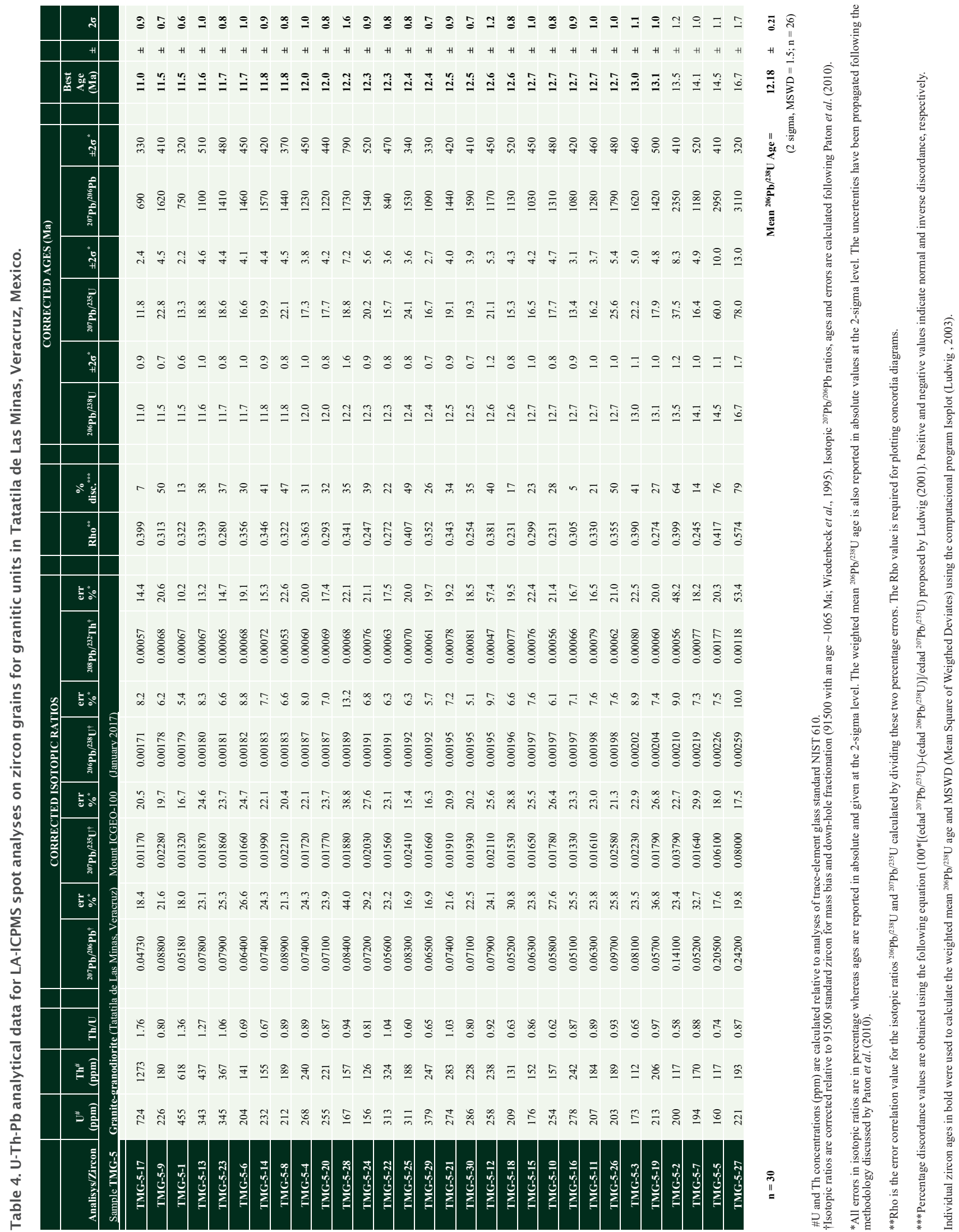


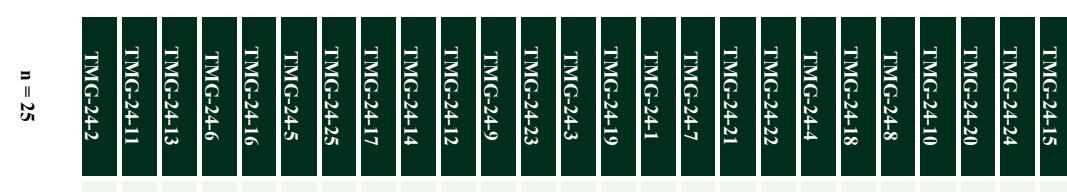

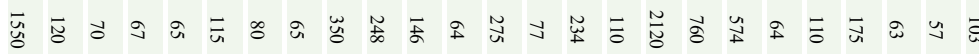

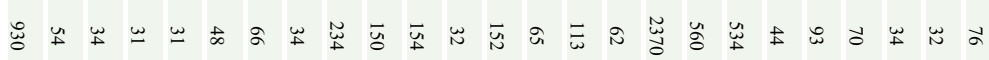

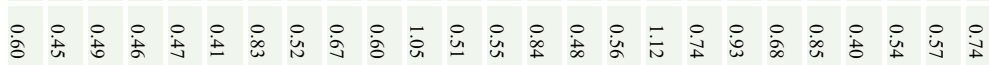

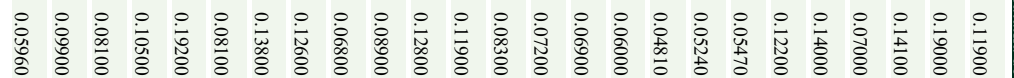

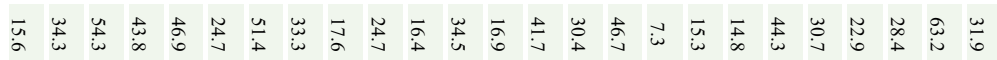

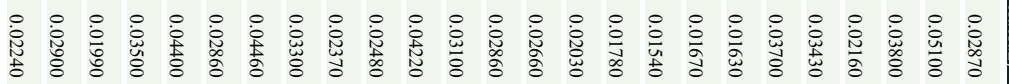

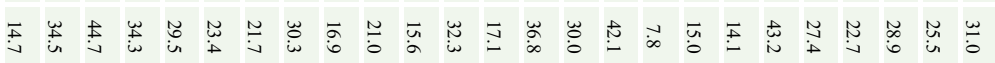
ใดी

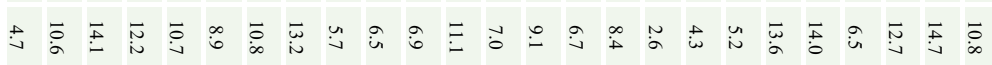

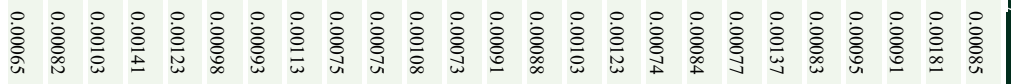

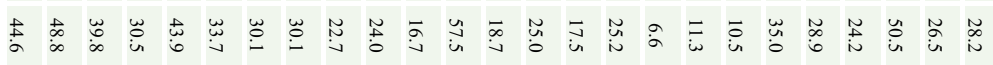

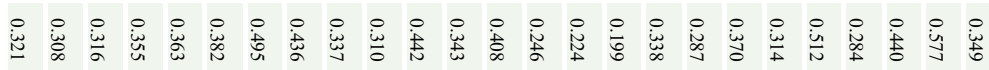
ㄹ ‡

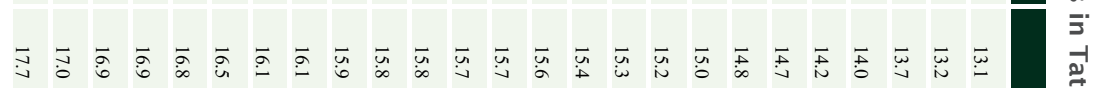

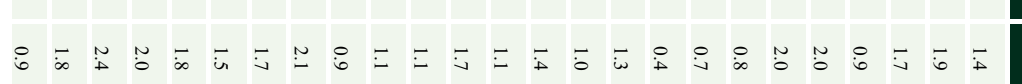

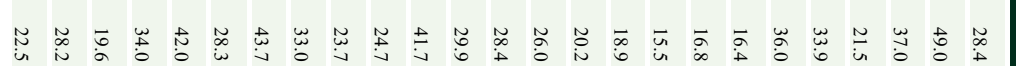

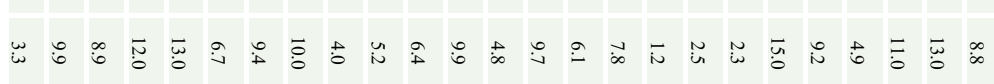
更

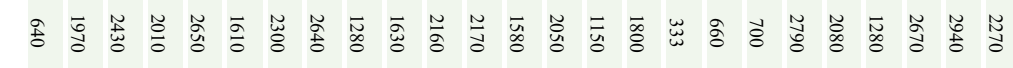

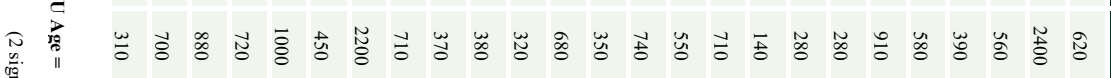

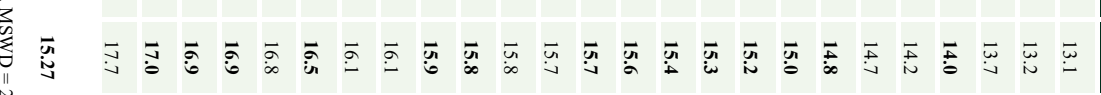

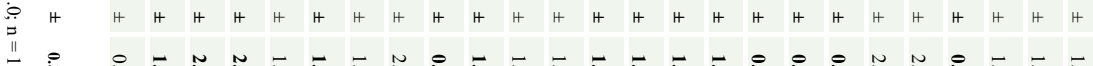

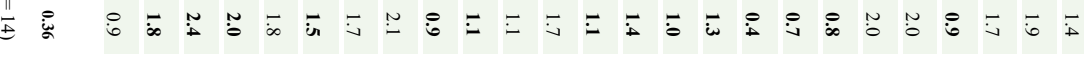


associations) yielded a U-Pb age of $12.18 \pm 0.21$ Ma, $(2 \sigma, \operatorname{MSWD}=1.5 ; \mathrm{n}=26$; Figure $6 \mathrm{~B})$.

The sample ES-3 from Escalona corresponds to a dyke that crosscuts the IOCG mineralization and yielded a $\mathrm{U}-\mathrm{Pb}$ weighted mean age at $4.11 \pm$ $0.11 \mathrm{Ma}(\mathrm{MSWD}=0.53, \mathrm{n}=8$; Figure 7A). A sample from Boquillas (BQ-1a, BQ-1b) yielded a $\mathrm{U}-\mathrm{Pb}$ weighted mean age at $286 \pm 2 \mathrm{Ma}$ (MSWD $=1.02, \mathrm{n}=6$; Artinskian, early Permian; Figure $7 \mathrm{E})$.

The intrusive rocks associated with the formation of IOCG deposits in the Tatatila-Las Minas area span compositions between those of sub-alkaline gabbros and granodiorites, and mostly concentrate in the granite, diorite and monzodiorite fields (Figure 8A). The geochemical affinity of the rocks is essentially metaluminous (Figure 8B), calc-alkaline (Figure 8C), and they plot within the fields of volcanic-arc granites (VAG) (Figure 9A) and I- and S-type granites (Figure 9B). Some samples have adakitic signatures (Figure 9D), mostly of the high-silica type (Figure 9E), thus indicating that their compositional variation is controlled mainly by partial melting (Figure 9G). Light rareearth and large-ion lithophile elements (LREE and LILE) are slightly enriched in such rocks (Figure 10) with respect to heavy rare-earth and high field strength elements (HREE and HFSE), as is characteristic for rocks associated with subduction, and conform with the results obtained by Dorantes-Castro (2016). Radiogenic isotope data range as follows: ${ }^{87} \mathrm{Sr} /{ }^{86} \mathrm{Sr}$ between 0.7040 and 0.7059, $\varepsilon$ Sr between -11.4 and $19.9,{ }^{143} \mathrm{Nd} /{ }^{144} \mathrm{Nd}$ between 0.5123 and $0.5128, \varepsilon N d$ between -6.6 and 3.2 , and ${ }^{206} \mathrm{~Pb} /{ }^{204} \mathrm{~Pb}$ between 18.65 and 18.75 (Table 3; Figure 11). The distribution of such data is in accordance with that determined by Gómez-Tuena et al. (2003) for rocks from the Trans-Mexican Volcanic Belt.

\section{Discussion}

\subsection{AGE CONSTRAINTS}

The ages (Figures 4 and 12; Table 5) of magmatic and hydrothermal episodes the Tatati-
la-Las Minas deposits range between 16.34 and 13.92 Ma for the associated intrusive bodies (all of them observed as direct contributors to prograde skarn formation), and between 12.49 and 12.18 Ma for hydrothermal minerals (retrograde skarn stages). It is important to emphasize that the analyzed rocks are not merely terms of an intrusive suite that included IOCG skarn generators, but IOCG skarn generators themselves, as the sampling strategy was directed to rocks spatially associated with such mineralizationwhether prograde or retrograde. The discussion to follow relies on this fact. The maximum time gap between prograde and retrograde skarn associations thus determined spans $\sim 1.5 \mathrm{My}$, which is similar to that defined for other skarn deposits (i.e., Camprubí et al., 2015). A late dyke that crosscuts the mineralization, in association with capping volcanic rocks of the Trans-Mexican Volcanic Belt, was dated at 4.11 Ma. The early Permian age obtained for intrusive rocks in the Las Minas area $(286 \pm 2 \mathrm{Ma})$ is likely to correspond to the Carboniferous-Permian arc (Ortega-Obregón et al., 2013; Kirsch et al., 2012), known as the Teziutlán massif, that constitutes the basement in the region and was dated at 269-252 Ma (K-Ar; López-Infanzón, 1991) and at $281-268 \mathrm{Ma}\left({ }^{40} \mathrm{Ar} /{ }^{39} \mathrm{Ar}\right.$; Iriondo et al., 2003).

A consistent range of ages between 24.60 and 19.04 Ma (late Oligocene to early Miocene; Figures 4 and 12; Table 5) has been additionally obtained, which corresponds to intrusive rocks that predate the syn-mineralization suite. Such ages also predate the earliest stage of magmatism that is associated with the Trans-Mexican Volcanic Belt (Gómez-Tuena et al., 2005, 2007) and are similar to those characteristic of the final stage of magmatic activity of the Sierra Madre Occidental (Ferrari et al., 2005b, 2007).

\subsection{PETROLOGIC AFFINITY}

The multielemental and isotopic geochemical determinations of IOCG skarn-related intrusive rocks at Tatatila-Las Minas are sound and congruent indicators of mostly intermediate 

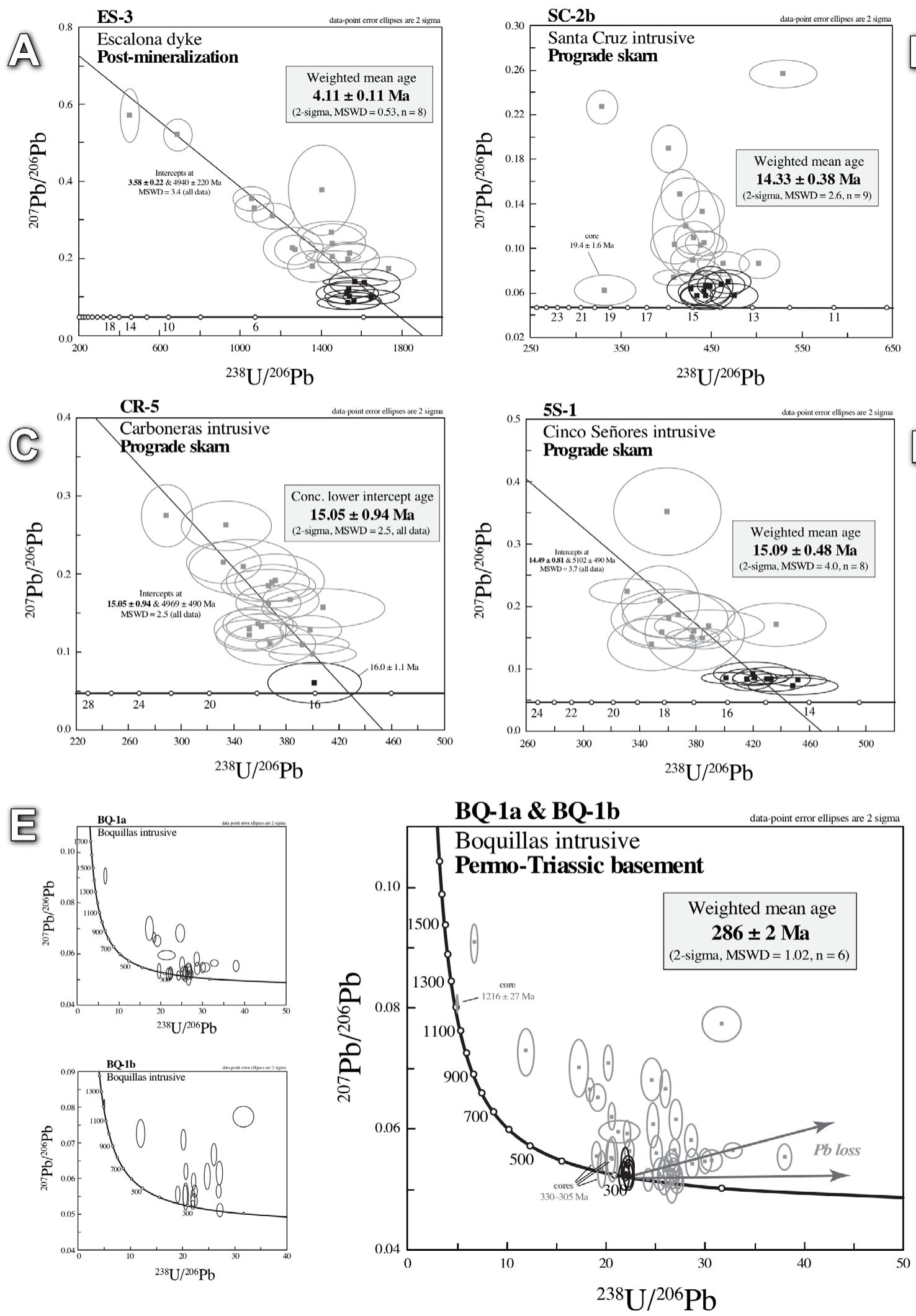

$\mathrm{U} / 206 \mathrm{~Pb}$

Figure 7 Tera-Wasserburg U-Pb concordia diagrams for zircons from various intrusive bodies in the Tatatila-Las Minas area. (A) Postmineralization dyke. (B to D) Syn-mineralization hypabyssal bodies whose age can be attributed to the prograde skarn associations. (E) Granitic intrusive that corresponds to the Permo-Triassic basement. Solid-line ellipses, with black square centers, are data used for age calculations; gray-line ellipses are data excluded from age calculations due to different degrees of $\mathrm{Pb}$-loss and/or zircon inheritance. All $\mathrm{U}-\mathrm{Pb}$ data are plotted with 2-sigma errors. Original U(Th)- $\mathrm{Pb}$ data can be found for inspection in Appendix 3. 


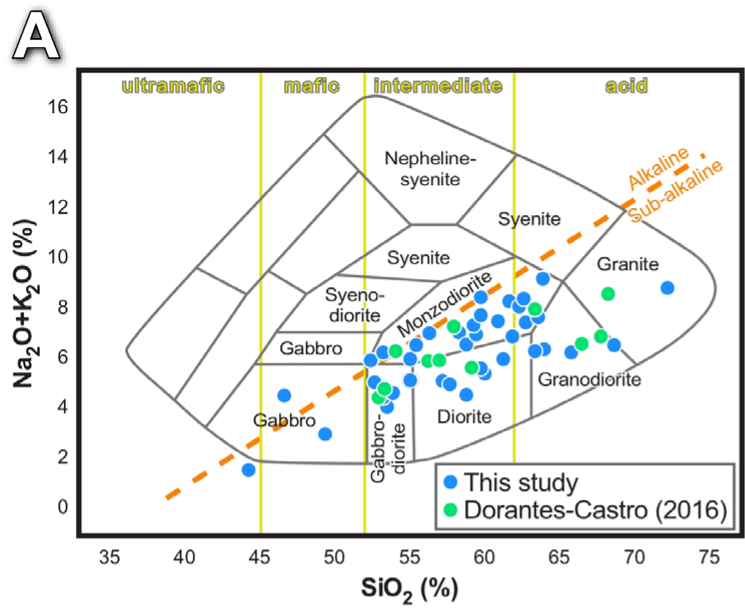

B

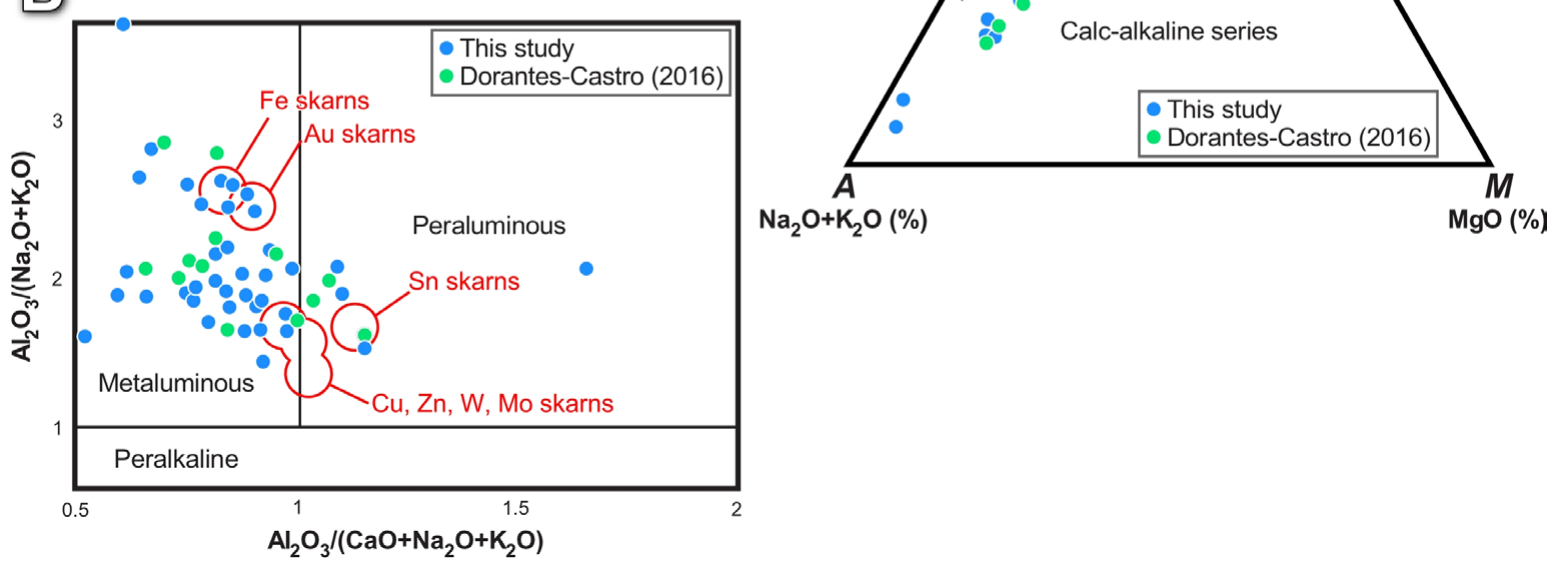

Figure 8 Petrological discrimination diagrams from major elements in intrusions associated with IOCG skarn mineralization in the TatatilaLas Minas district, Veracruz. (A) Silica vs. alkaline element bivariant diagram, adapted from Cox et al. (1979). (B) Alumina saturation diagram, adapted from Frost et al. (2001), with compositions of skarns from Meinert (1995). (C) AFM diagram, adapted from Irvine and Baragar (1971).

to acid (Figure 8A), metaluminous (Figure 8B), and I- and S-type rocks (Figure 9B) that were emplaced in a subduction-related continental arc (Figure 9A), and high $\mathrm{La} / \mathrm{Yb}$ ratios could also be obtained through high pressures in basaltic melt (Figure 9C; McPherson et al., 2006), since the late Oligoce to Miocene. In addition, these rocks are part of the medium- to high-potassium (not shown) calc-alkaline series, with adakitic signatures and a compelling isotopic affinity with the Trans-Mexican Volcanic Belt (TMVB). A sound adakitic affinity of most analyzed samples in the study area is determined by a general geochemical behavior (Tables 1 to 3; Figure 9D, E) that meets most of the characteristics of such petrological association (Table 6). If anything, Y and $\mathrm{Yb}$ contents appear to be significantly higher than in adakitic (Tables 3 and 6), a characteristic that will be addressed later on. Despite the possible occurrence of alkaline magmatism in the Palma Sola region in association with the Eastern Mexico Alkaline Province (EMAP; Demand and Robin, 1975; Negendank et al., 1985; Ferrari et al., 2005a), the formation of IOCG skarn deposits in the Tatatila-Las Minas district can be solely attributed to the TMVB, as no adakitic affinity has been consistently reported for the magmatism associated with the EMAP (see references in Camprubí, 2013). However, some ages of alkaline rocks in Palma Sola are much younger than syn-mineralization ages, with no associated mineralization. Then, the adakitic signatures 
Table 5. Summary of geochronometric data obtained for host intrusive rocks and IOCG mineralization at the Tatatila-Las Minas area.

\begin{tabular}{|c|c|c|c|c|}
\hline Sample / location & Association & Method / mineral & $\operatorname{Age} \pm 2 \sigma(\mathrm{Ma})$ & Comments \\
\hline \multicolumn{5}{|c|}{ Tatatila-Las Minas district } \\
\hline $\begin{array}{l}\text { BQ-1a, BQ-1b / } \\
\text { Boquillas }\end{array}$ & Granite & $\mathrm{U}-\mathrm{Pb} /$ zircon & $286 \pm 2$ & $\begin{array}{l}\text { Early Permian granitoids in the } \\
\text { Permo-Triassic basement }\end{array}$ \\
\hline CR-1 / Carboneras & Granodiorite & ${ }^{40} \mathrm{Ar} /{ }^{39} \mathrm{Ar} /$ biotite & $24.60 \pm 1.10$ & $\begin{array}{l}\text { Pre-mineralization intrusive } \\
\text { suite (late Oligocene to early } \\
\text { Miocene) }\end{array}$ \\
\hline CR-1 / Carboneras & Granodiorite & ${ }^{40} \mathrm{Ar} /{ }^{\beta 9} \mathrm{Ar} / \mathrm{HB}$ & $23.40 \pm 2.50$ & \\
\hline BQ-1c / Boquillas & Granite & ${ }^{40} \mathrm{Ar} /{ }^{39} \mathrm{Ar} / \mathrm{KF}$ & $22.12 \pm 0.74$ & \multirow{3}{*}{$\begin{array}{l}\text { Transition between the Sierra } \\
\text { Madre Occidental and the } \\
\text { Trans-Mexican Volcanic Belt? }\end{array}$} \\
\hline RV-2 / Vaquería & Granite & ${ }^{40} \mathrm{Ar} /{ }^{39} \mathrm{Ar} / \mathrm{KF}$ & $20.67 \pm 0.57$ & \\
\hline CR-1 / Carboneras & Granodiorite & ${ }^{40} \mathrm{Ar} /{ }^{39} \mathrm{Ar} / \mathrm{KF}$ & $19.04 \pm 0.69$ & \\
\hline SC-2-b1 / Santa Cruz & Granodiorite & ${ }^{40} \mathrm{Ar} /{ }^{39} \mathrm{Ar} /$ biotite & $16.34 \pm 0.20$ & \multirow{4}{*}{ 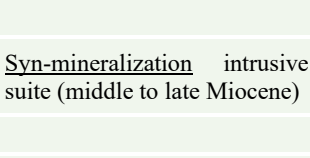 } \\
\hline SC-2a / Santa Cruz & Granodiorite & ${ }^{40} \mathrm{Ar} /{ }^{39} \mathrm{Ar} /$ biotite & $15.43 \pm 0.16$ & \\
\hline TMG-24 / Santa Cruz & Qz-monzonite & U-Pb / zircon & $15.27 \pm 0.36$ & \\
\hline 5S-1 / Cinco Señores & Granite & $\mathrm{U}-\mathrm{Pb} /$ zircon & $15.09 \pm 0.48$ & \\
\hline CR-5 / Carboneras & Granodiorite & $\mathrm{U}-\mathrm{Pb} /$ zircon & $15.05 \pm 0.94$ & \multirow{6}{*}{$\begin{array}{l}\text { Matches with the middle to late } \\
\text { Miocene age range of intrusive } \\
\text { bodies of gabbroic to dioritic } \\
\text { composition defined by Ferrari } \\
\text { et al. (2005a) at the Palma Sola } \\
\text { massif, east of the Tatatila-Las } \\
\text { Minas area }\end{array}$} \\
\hline BQ-1b / Boquillas & Granite & ${ }^{40} \mathrm{Ar} /{ }^{39} \mathrm{Ar} /$ biotite & $14.60 \pm 0.34$ & \\
\hline SC-2b / Santa Cruz & Granodiorite & ${ }^{40} \mathrm{Ar} /{ }^{39} \mathrm{Ar} /$ biotite & $14.46 \pm 0.15$ & \\
\hline SC-2b / Santa Cruz & Granodiorite & $\mathrm{U}-\mathrm{Pb} /$ zircon & $14.33 \pm 0.38$ & \\
\hline BQ-1b / Boquillas & Granite & ${ }^{40} \mathrm{Ar} /{ }^{39} \mathrm{Ar} /$ biotite & $13.92 \pm 0.22$ & \\
\hline FSC-1 / Santa Cruz & mineralization & ${ }^{40} \mathrm{Ar} /{ }^{39} \mathrm{Ar} / \mathrm{CM}$ & $12.49 \pm 0.09$ & \\
\hline TMG-5 / Tatatila & mineralization & $\mathrm{U}-\mathrm{Pb} /$ zircon & $12.18 \pm 0.21$ & \\
\hline Es-3 / Escalona & Granodiorite & $\mathrm{U}-\mathrm{Pb} /$ zircon & $4.11 \pm 0.11$ & Post-mineralization intrusives \\
\hline \multicolumn{5}{|c|}{$\underline{\text { Regional intrusive ages }}$} \\
\hline Laguna Verde & microdiorite & & 17 & $\begin{array}{l}\text { Cantagrel and Robin (1979), } \\
\text { deemed as unreliable by Ferrari } \\
\text { et al. (2005a) }\end{array}$ \\
\hline Junique & gabbro & ${ }^{40} \mathrm{Ar} /{ }^{39} \mathrm{Ar}$ & $15.62 \pm 0.5$ & Ferrari et al. (2005a) \\
\hline Plan de las Hayas & hypabyssal rock & ${ }^{40} \mathrm{Ar} /{ }^{39} \mathrm{Ar}$ & $14.65 \pm 0.32$ & Ferrari et al. (2005a) \\
\hline \multirow{3}{*}{$\begin{array}{l}\text { Tenochtitlan to } \\
\text { Junique }\end{array}$} & \multirow{3}{*}{ granitic plutons } & & $13.0 \pm 1.0$ & \multirow{3}{*}{ López-Infanzón (1991) } \\
\hline & & & $9.0 \pm 0.7$ & \\
\hline & & & $6.2 \pm 0.6$ & \\
\hline \multirow{2}{*}{ Candelaria } & \multirow{2}{*}{ gabbro } & & 12.3 and 12.9 & Negendank et al. (1985) \\
\hline & & ${ }^{40} \mathrm{Ar} /{ }^{39} \mathrm{Ar} / \mathrm{PL}$ & $10.9 \pm 0.8$ & Ferrari et al. (2005a) \\
\hline El Limón & hypabyssal rock & ${ }^{40} \mathrm{Ar} /{ }^{39} \mathrm{Ar}$ & $11.07 \pm 0.2$ & Ferrari et al. (2005a) \\
\hline \multirow{2}{*}{\multicolumn{3}{|c|}{ Whole range of ages of magmatism in the Palma Sola massif }} & 15.6 to 10.9 & Ferrari et al. (2005a) \\
\hline & & & 17 to 7.5 & Camprubí $(2009,2013)$ \\
\hline
\end{tabular}

found in the Palma Sola region are more likely to correspond to the volcanism of the TMVB rather than that of the EMAP. This is the first instance in which adakites are directly associated with the formation of any ore deposits in the TMVB - in this case, IOCG skarn deposits.

However, anomalously high $\mathrm{Y}$ and $\mathrm{Yb}$ contents (with respect to typical adakitic signatures) similar to those found in the Tatatila-Las Minas host rocks have been explained in adakites as to reflect some degree of interaction with alkaline or ultrapotassic rocks (Lu et al., 2013; Liu et al., 2017)-hence the high-potassium character of many of the studied rocks (?) - or due to crustal contamination (Zhang et al., 2017). Therefore, despite the likely dominant affinity of these rocks with the TMVB, some degree of interaction between their parental TMVB magmas and EMAP magmas cannot be ruled out at this 

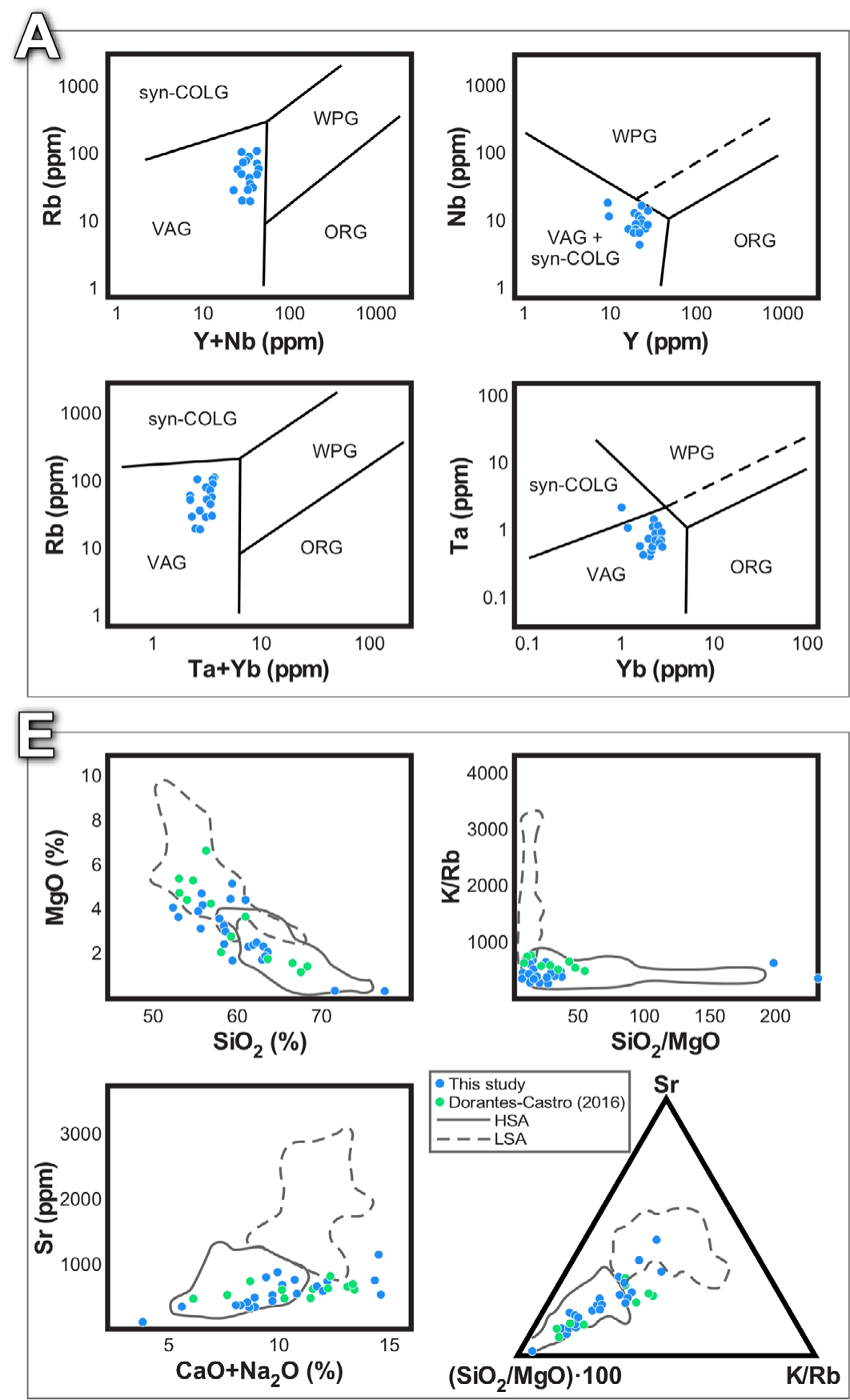
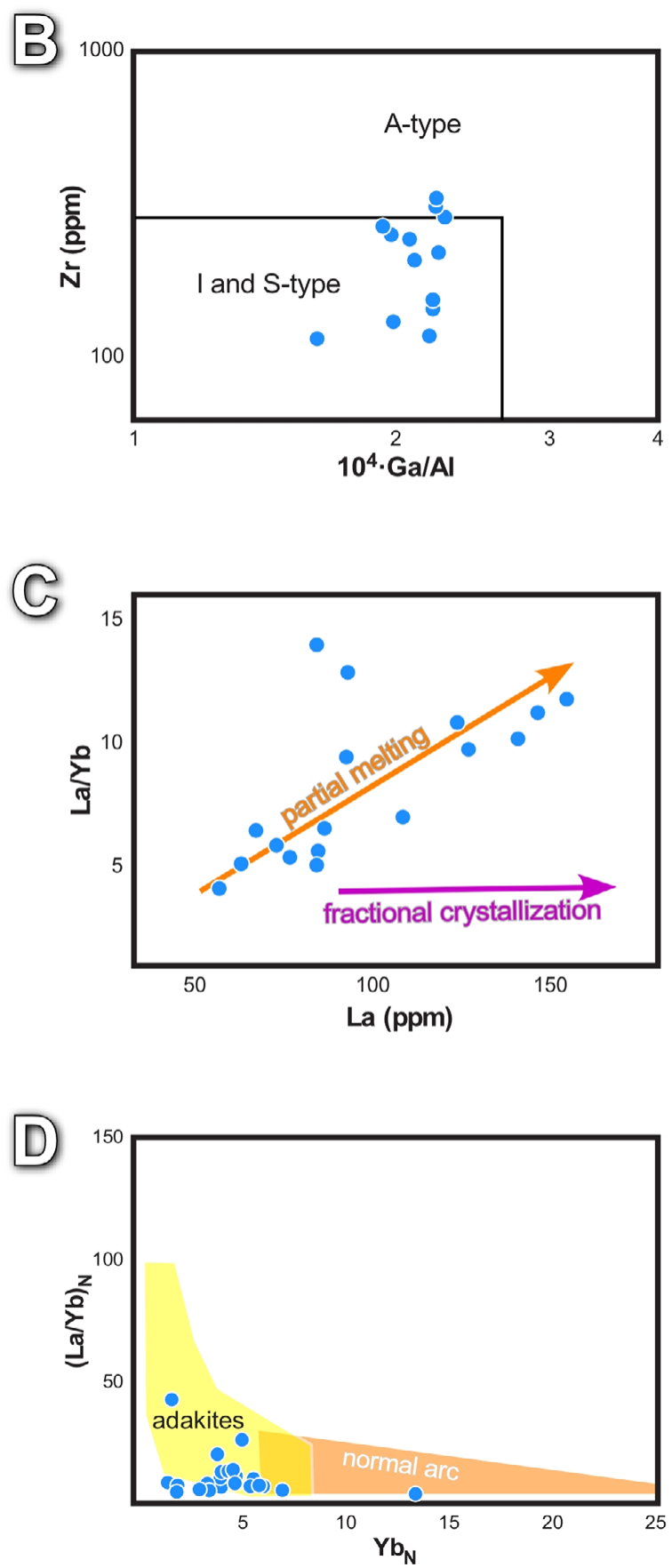

Figure 9 Petrological discrimination diagrams from trace elements in intrusive rocks associated with IOCG skarn mineralization in the Tatatila-Las Minas district, Veracruz. (A) $\mathrm{Y}+\mathrm{Nb}$ vs. $\mathrm{Rb}, \mathrm{Y}$ vs. $\mathrm{Nb}, \mathrm{Ta}+\mathrm{Yb}$ vs. Rb, and $\mathrm{Yb}$ vs. Ta diagrams for discriminating tectonic settings, adapted from Pearce et al. (1984). (B) Discrimination diagram for different granite sources, adapted from Whalen et al. (1987). (C) Discrimination diagram for the generation of magmas by fractional crystallization vs. variable degree of partial melting, adapted from Thirlwall et al. (1994). (D) Discrimination diagram for adakitic affinity, adapted from Martin (1986) with chondrite-normalized values Sun and McDonough (1989).

(E) Discrimination diagrams for high-silica (HSA) and low-silica adakites (LSA), adapted from Martin and Moyen (2002, 2003) and Martin et al. (2005). Key: $\mathrm{HSA}=$ high-silica adakites $\left(>60 \% \mathrm{SiO}_{2}\right)$, $\mathrm{LSA}=$ low-silica adakites $\left(<60 \% \mathrm{SiO}_{2}\right)$, ORG $=$ ocean ridge granites, VAG $=$ volcanic arc granites, syn-COLG = syn-collision granites, WPG = within plate granites. 
Table 6. Comparative table between the general geochemical composition of adakites (as of Mori et al., 2007; Richards and Kerrich, 2007) and of intrusive rocks at the Tatatila-Las Minas area.

\begin{tabular}{|c|c|c|c|}
\hline & "Normal" adakites & Tatatila-Las Minas & \\
\hline $\mathrm{SiO}_{2}($ wt. \%) & $\geq 56$ & $\sim 44$ to 68 & \\
\hline $\mathrm{Al}_{2} \mathrm{O}_{3}(\mathrm{wt} . \%)$ & $\geq 15$ & $\sim 14$ to 21 & \\
\hline MgO (wt.\%) & $\sim<3$ & $<1$ to $\sim 11$ & Mostly <6.7 wt. $\%$ \\
\hline $\mathrm{Na}_{2} \mathrm{O}($ wt.\%) & 3.5 to 7.5 & $\sim 3$ to 5 & \\
\hline $\mathrm{K}_{2} \mathrm{O} / \mathrm{Na}_{2} \mathrm{O}$ & $\sim 0.42$ & 0.1 to 1.2 & Mostly 0.4 to 0.6 \\
\hline HREE & depleted & depleted & \\
\hline $\mathrm{Sr}$ (ppm) & $\geq 400$ & $\sim 16$ to 734 & \\
\hline Y (ppm) & $\leq 18$ & $\sim 3$ to 50 & Mostly between 20 and $40 \mathrm{ppm}$ \\
\hline Yb (ppm) & $\leq 1.9$ & $\sim 0$ to 16 & Mostly $<3$ ppm \\
\hline $\mathrm{Cr}$ (ppm) & $\geq 30$ & $\sim 2$ to 439 & 9 out of 25 values are $\geq 30 \mathrm{ppm}$ \\
\hline $\mathbf{S r} / \mathbf{Y}$ & $\geq 20$ & $\sim 7$ to 190 & \\
\hline $\mathbf{L a} / \mathbf{Y b}$ & $\geq 20$ & $\sim 5$ to 13 & \\
\hline${ }^{87} \mathrm{Sr} /{ }^{86} \mathrm{Sr}$ & $\leq 0.7045$ & 0.7037 to 0.7059 & \\
\hline$\overline{\varepsilon N d}$ & -0.1 to 1.7 & -6.6 to 3.2 & \\
\hline$\varepsilon \mathrm{Sr}$ & & -11.4 to 19.9 & \\
\hline
\end{tabular}

stage of research. As a matter of fact, magmas with either affinity coexisted in the region, as evidenced by the formation of the Tatatila-Las Minas deposits (Negendank et al., 1985; Ferrari et al., 2005a; see also Figure 7 in Camprubí, 2009). Also, the occurrence of A-type granites (alkaline) is hinted at in some of the analyzed samples despite mostly belonging to I- and S-types (Figure 9B), but no affinity with within-plate granites was found (Figure 9A).

In addition, the data in this paper stand for the idea of a metallogeny of the TMVB in its own right, as established by Camprubí (2013). The ages of Miocene IOCG skarn-related magmatism in the Tatatila-Las Minas area (16.34 to $13.92 \mathrm{Ma}$ ) fit well within the $\sim 19$ to 10 Ma bracket defined by Gómez-Tuena et al. $(2005,2007)$ for the early stages of the TMVB, particularly in its eastern region, in which the adakitic signature of volcanism is conspicuous. Such continental magmatism display geochemical signatures that strongly evoke those of adakites, with the inherent likeliness that it may be associated with melting of the flattened subducted slab (Gómez-Tuena et al., 2005, 2007; Mori et al., 2007). Adakite is the common term that refers to magmas produced by melting of subducted oceanic crust under high pressures and in the presence of water (due to dehydration of the subducted slab).
However, other processes for magma generation are possible in the generation of magmas with adakitic geochemical signatures (Defant et al., 2002; Richards and Kerrich, 2007; Rodríguez et al., 2007; Richards, 2011; Ma et al., 2015; Ribeiro et al., 2016; Deng et al., 2017; Keevil et al., 2019). The adakitic signatures at a regional scale in the TMVB are the very high $\mathrm{Sr} / \mathrm{Y}$ ratios, depletion in $\mathrm{Y}$ and HREE, and $\mathrm{Sr}, \mathrm{Nd}$ and $\mathrm{Pb}$ isotopic compositions that approximate to those of mid-ocean ridge basalts in the East Pacific Rise (Gómez-Tuena et al., 2005, 2007; Mori et al., 2007). Nonetheless, adakitic affinities do not necessarily imply that these magmas are derived from the melting of the subducted slab alone, and other geological mechanisms are also plausible for their inception or as relevant contributors to adakitic signatures, as discussed below.

\subsection{ORIGIN OF ADAKITIC COMPOSITIONS AND LINKAGE WITH ORE DEPOSITS}

The linkage between adakitic magmas and the variety of tectonomagmatic settings that the generation of such magmas entails is suggestive of a significant potential for the formation of associated ore deposits (González-Partida et al., 2003a, 2003b; Chiaradia et al., 2004; Sun et al., 2011; 
Deng et al., 2017; Keevil et al., 2019). Although the association between "adakites" and ore deposits normally refers to the classic definition of adakite magmas, the generation of such magma through melting of a subducted slab has been questioned (Richards and Kerrich, 2007; Richards, 2011). In the case of Tatatila-Las Minas, however, the intrusive rocks of adakitic-affinity associated with IOCG skarn mineralization have dominantly high-silica compositions (Figure 9E). This denotes that melting of basalt from the subducted slab would have effectively occurred, with subsequent reaction of the resulting melts with peridotites during their ascent through the mantle wedge (Defant and Drummond, 1990; Drummond and Defant, 1990; Martin et al., 2005). Also, the distribution of $\mathrm{Nd}$ and $\mathrm{Sr}$ isotopic compositions in the Tatatila-Las Minas intrusions point to magma fractionation as per their distribution (Figure 11A). $\varepsilon N d$ values in the analyzed rocks (between -6.6 and 3.2; Table 3) point to contributions of both relatively isotopically enriched and depleted magma sources for $\mathrm{Nd}$, and represent mantle derived melts that were contaminated by continental crust lithologies, especially when correlated with $\varepsilon S r$ values (Figure 11D). As already highlighted by Gómez-Tuena et al. (2003), Pb isotopic compositions lie between those expected for subducted sediments and MORB (Figure 11B, $11 \mathrm{C}$ and Table 3), thus requiring an isotopically depleted source.

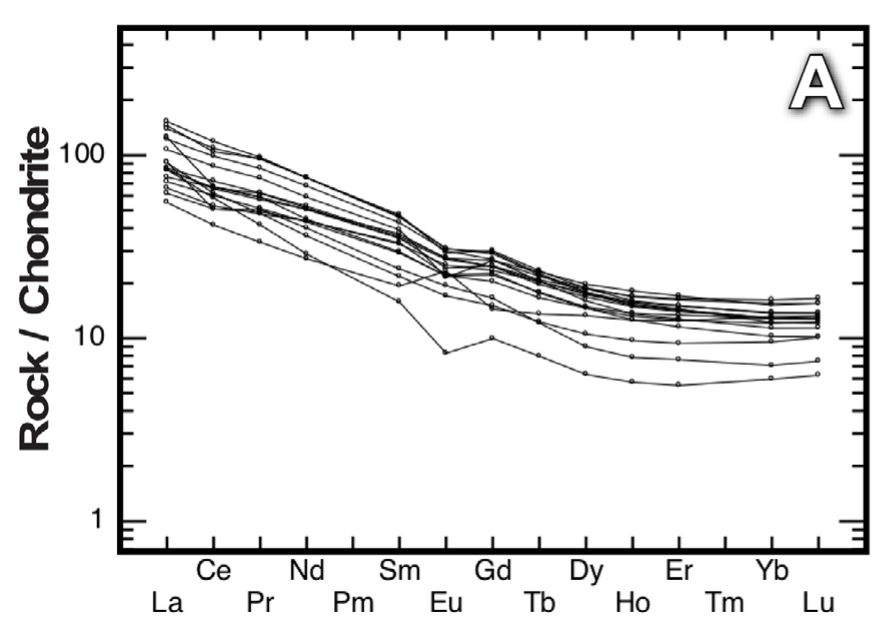

An association between adakites and the formation of IOCG skarn deposits was earlier established in Mexico for the late Cretaceousearly Paleocene Mezcala deposits in the Sierra Madre del Sur (Camprubí and González-Partida, 2017, and references therein). The formation of adakites in that locality has been linked to early stages of a subduction-related continental arc (González-Partida et al., 2003b), a feature that is explained by the switch from subduction-related oceanic arcs to continental arcs in southern Mexico during the Late Cretaceous (Camprubí, 2013, 2017). Besides the particular case of Mezcala, in these and the Tatatila-Las Minas deposits the formation of associated adakitic magmas can be explained by slab rollback or flattening subduction as younger portions of the subducted slab were being consumed (Morán-Zenteno et al., 1999; Ferrari and Rosas-Elguera, 1999; Gutscher et al., 2000; Gómez-Tuena et al. 2003; Keppie and Morán-Zenteno, 2005). Also, in both regions similar associations of different magmatic-hydrothermal types of deposits (i.e., IOCG, sulfide skarns, metalliferous porphyries, epithermal deposits; Camprubí, 2013, 2017) were produced. Such flattening of the subducted slab has been extensively documented along the entire Western Cordillera of North America and the Andes and explains the historical distribution of metallogenic provinces within them (Camprubí, 2017, and references within).

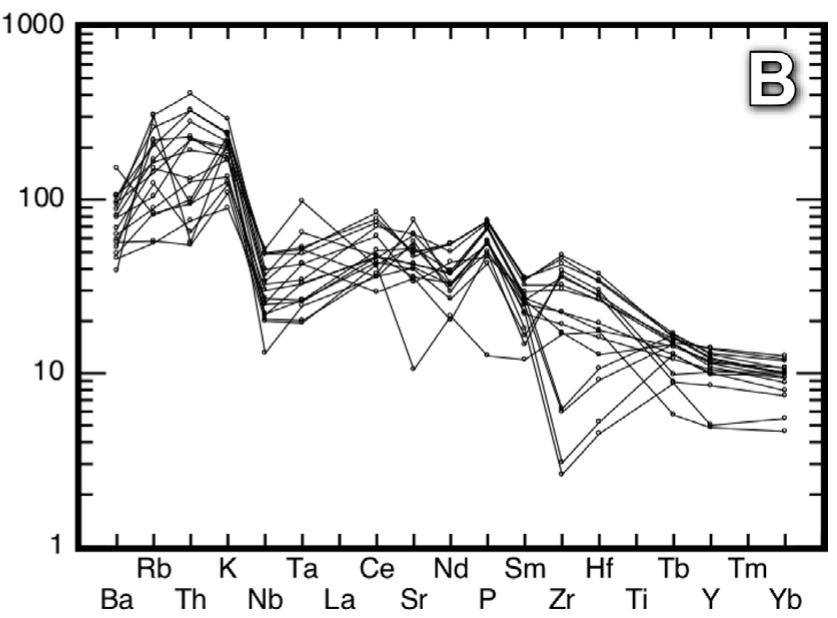

Figure 10 Spider diagrams of REE (A) and trace element contents (B) normalized to chondrite (Sun and McDonough, 1989). 
However, magmatic processes such as assimilation and fractional crystallization $(\mathrm{AFG})$ or those occurring in melting-assimilation-storage-homogenization (MASH) zones in "normal" continental arc magmas may also account for adakitic compositions of intrusions in association with the subsequent formation of magmatic-hydrothermal ore deposits (Richards and Kerrich, 2007; Richards, 2011; Gatzoubaros et al., 2014; Lohmeier et al., 2019). fact, these processes can generate andesitic to dacitic differentiates with HREE-depleted normalized REE patterns, and high La/ $\mathrm{Yb}$ and $\mathrm{Sr} / \mathrm{Y}$ ratios (Feeley and Davison, 1994; Kay et al., 1999; Klepeis et al., 2003; Richards, 2011). However, AFG processes can be virtually ruled out as important contributors to the adakitic signal because Eu anomalies in this case are weak (Figure 10; see Chen et al., 2014). The absence of $\mathrm{Eu}$ anomalies would support the model by Richards (2011), as high water contents in typical adakitic rocks are characteristic of MASH zones. MASH interactions may involve partial melts of lower crustal rocks that may imprint high La/ $\mathrm{Yb}$ and $\mathrm{Sr} / \mathrm{Y}$. Such signature is derived from high pressure fractionation in MASH zones with amphibole and garnet, which would produce high $\mathrm{La} / \mathrm{Yb}$ ratios, and from the suppression of plagioclase fractionation due to high water content in the magmas, thus resulting in high $\mathrm{Sr} / \mathrm{Y}$ ratios (see references in Richards, 2011). In low $f \mathrm{~S}_{2}$ and high $f \mathrm{O}_{2}$ conditions underneath "normal" continental arcs, MASH processes may induce the formation of IOCG deposits in intra-arc settings (Richards and Mumin, 2013), thus producing an alternative scenario for the association between adakite-like and IOCG deposits. With regard to slab flattening underneath a continental arc due to steep subduction, Richards and Mumin (2013) argued about scarce to nil associated magmatic activity or the migration of magmatism toward back-arc settings. Interestingly, slab flattening would cause the dehydration of the slab and the subsequent hydration of the lithosphere, which would be too cold to melt. However, once the slab re-steepened, the temperature of the hydrated lithosphere would rise in contact with the asthe- nosphere, generating the partial melting of sub-continental mantle and subsequent vigorous volcanic flare-ups, thus reactivating the formation of magmatic-hydrothermal ore deposits - among them, IOCG deposits (see Figure 1 in Richards and Mumin, 2013). The formation of adakites in such specific settings and in association with magmatic-hydrothermal ore deposits has not been reported. However, the involvement of MASH-type processes in metallogeny has actually been invoked in the formation of continental-arc related magmatic-hydrothermal ore deposits nonetheless (Sun et al., 2011). The possibility of magma generation by MASH-type processes that followed re-steepening of the subducted slab with which the formation of IOCG deposits would be linked is particularly significant for the TatatilaLas Minas case. Indeed, the formation of these deposits occurred during the late Miocene, once the subducted slab underneath the Trans-Mexican Volcanic Belt, in fact, re-steepened (see Figure 13 in Gómez-Tuena et al., 2003).

In summary, the most likely settings for the formation of parental adakitic magmas to the IOCG skarn deposits at Tatatila-Las Minas would be (1) a "normal adakitic" slab-melt setting with some crustal contamination, or (2) MASH-related adakitic compositions. However, these settings do not necessarily have to be considered as mutually exclusive in the generation of adakites with associated magmatic-hydrothermal ore deposits (Chen et al., 2014; Sun et al., 2018). To our reckoning, these settings cannot be effectively discriminated given the current wealth of data from the TatatilaLas Minas district. In addition, it is possible that TMVB calc-alkaline and EMAP alkaline magmas underwent some kind of interaction that produced the intrusive bodies with which the studied IOCG skarn deposits are associated. Interestingly, despite the common tectonomagmatic affinity of all the Cenozoic magmatic rocks, the only samples that show high $\mathrm{Y}$ and $\mathrm{Yb}$ contents are those whose ages correspond entirely to the initial stages of the TMVB (not those older than $19 \mathrm{Ma}$ ). This, again, stands for different magmatic processes - albeit slightly - between TMVB and pre-TMVB rocks. 

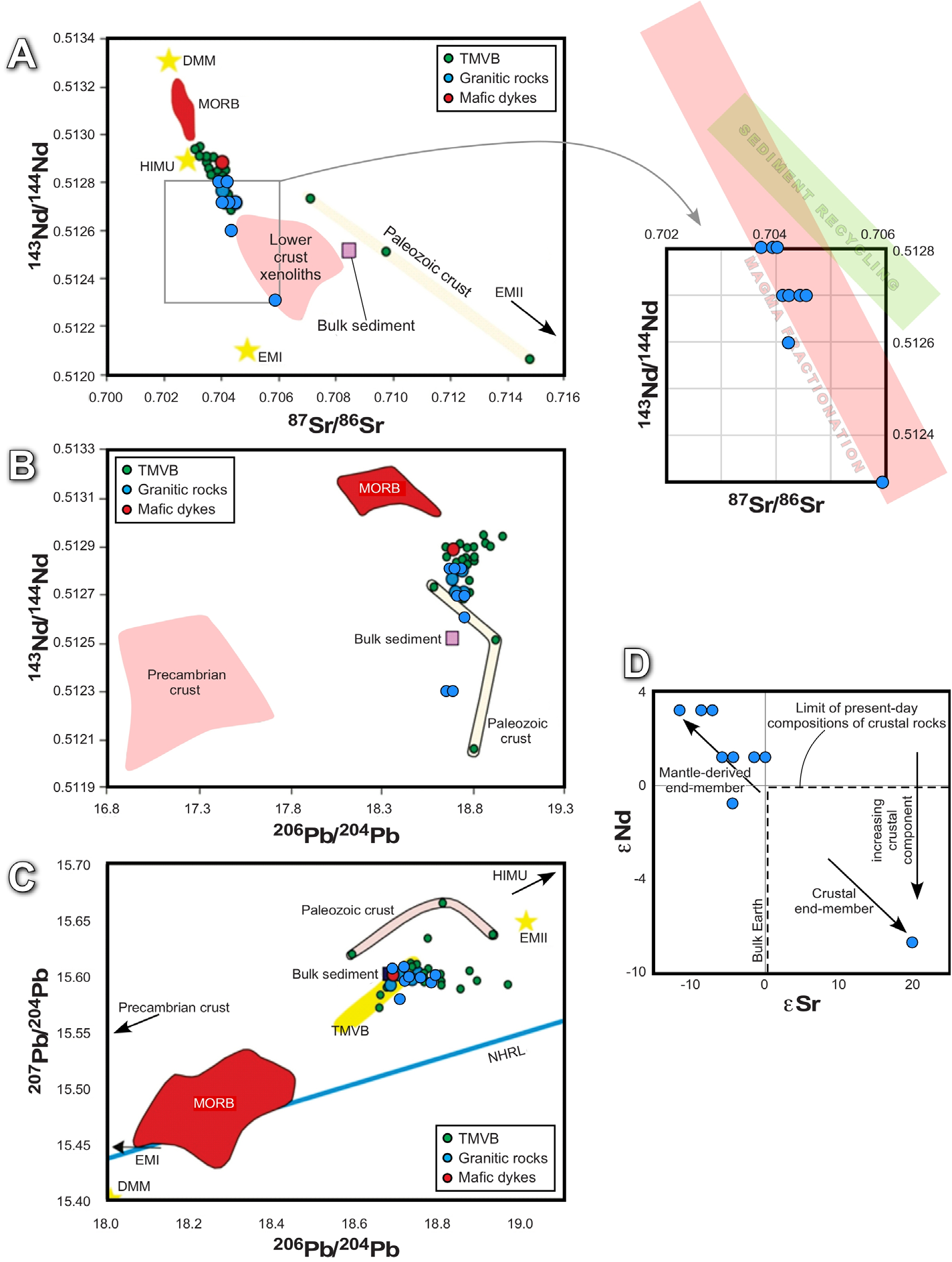

Figure 11 Isotope variation diagrams for the Tatatila-Las Minas Miocene intrusive bodies associated with IOCG skarn mineralization. (A) $\mathrm{Sr}$-Nd isotopes variation diagram. (B) $\mathrm{Pb}-\mathrm{Nd}$ isotopes variation diagram. (C) $\mathrm{Pb}$ isotopes variation diagram. (D) $\varepsilon \mathrm{Nd}$ vs. $\varepsilon S r$ diagram that illustrates possible end-member sources for magmas, after DePaolo and Wasserburg (1979a, 1979b). Key = DMM = depleted MORB-mantle, $\mathrm{EMI}=$ enriched mantle I, EMII = enriched mantle II, HIMU = mantle component, MORB $=5^{\circ}-15^{\circ} \mathrm{NE}$ Pacific Rise mid-ocean ridge basalts, NHRL $=$ northern hemisphere reference line, $T M V B=$ current volcanic front of the Trans-Mexican Volcanic Belt. See sources for all reference values in Gómez-Tuena et al. (2003), which is also the source of values represented as green dots in diagrams A to C that correspond to volcanic rocks from the Palma Sola area in the eastern TMVB. The magmatic fractionation and sediment recycling trends in the zoomed view of $A$ are simplified after Hoffman and White (1982). 


\section{Conclusions}

The iron oxide-Cu-Au deposits at the Tatatila-Las Minas district (central Veracruz) are skarn-related deposits that belong to the IOCG family, and associated Au-rich epithermal deposits also occur in the area. U-Pb and ${ }^{40} \mathrm{Ar} /{ }^{39} \mathrm{Ar}$ dating of these IOCG skarns yielded early to middle Miocene ages for prograde (16.34 to $13.92 \mathrm{Ma}$ for the associated intrusive bodies) and retrograde (12.44 to 12.18 Ma for hydrothermal minerals) associations. Such ages and the geochemical affinity of host intrusive rocks (calc-alkaline to adakitic) that are directly involved in the formation of IOCG skarns match well with those previously established for the early stages of evolution of the Trans-Mexican Volcanic Belt (TMVB). A set of pre-TMVB Cenozoic rocks has been also dated between 24.6 and $19 \mathrm{Ma}$.
The multi-elemental and isotopic geochemical study of IOCG skarn-related intrusive rocks determined that these are intermediate to acid, metaluminous, I- and S-type, medium- to high-potassium, typical calc-alkaline to adakitic rocks that are compatible with those expected for a continental volcanic arc such as the TMVB. Therefore, the studied deposits are likely to be ascribed to the metallogeny of the TMVB, which can be rightfully spoken of as an actual metallogenic province. Such a fact broadens the economic expectations of a province that has traditionally been overlooked by mineral exploration.

The prominent adakitic signal as found in the IOCG skarn-generating intrusive rocks has been regionally attributed to adakitic melts associated with flat subduction and the subsequent resteepening of the subducted slab- with independent

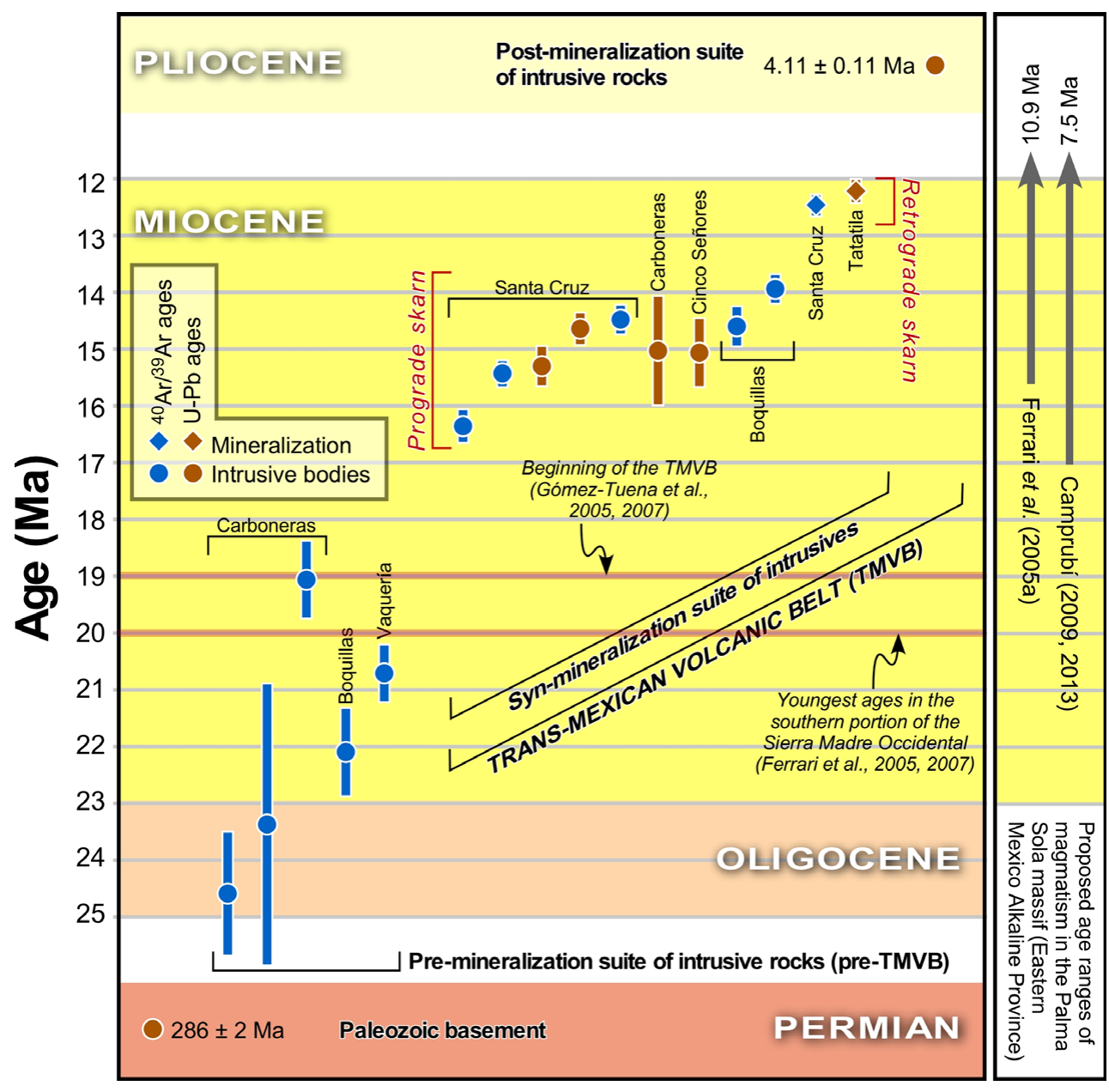

Figure 12 Summary of the U-Pb and ${ }^{39} \mathrm{Ar} /{ }^{40} \mathrm{Ar}$ ages obtained in this study for the intrusive rocks and IOCG skarn mineralization at the Tatatila-Las Minas area, Veracruz. 
evidence for crustal contamination. The results in this paper concur with such an interpretation. The general geochemical characteristics of these rocks, however, do not rule out the possibility that melting-assimilation-storage-homogenization (MASH) processes were involved in the generation of parental magmas. There are also hints that these magmas interacted with alkaline melts, which would likely be associated with the nearly contemporaneous EMAP. Only TMVB rocks display $\mathrm{Y}$ and $\mathrm{Yb}$ contents that would suggest such interaction - all other petrologic indicators suggest common characteristics for TMVB and pre-TMVB Cenozoic rocks. In both a adakitic and MASH scenarios, the most plausible stage at which the formation of IOCG skarn-associated magmas occurred would be once the flattened subducted slab re-steepened, thus allowing melting of either (or both) slab material or the hydrated lower lithosphere.

\section{Acknowledgements}

This paper constitutes a part of the dissertations of E.F.G. and G.H.A., who acknowledge the support of CONACyT through $\mathrm{PhD}$ and MSc grants, respectively. The Instituto de Geología UNAM is acknowledged for authorizing E.F.G. to carry on her $\mathrm{PhD}$ research along with her academic duties. Funding for this work was provided by CONACyT through the research grants 155662 to A.C. and "GEMex: Cooperación México-Europa para la investigación de sistemas geotérmicos mejorados y sistemas geotérmicos supercalientes" (within the 4.1 and 8.2 research sections: Determinación de propiedades petrológicas, de alteración hidrotermal, microtermométricas, geoquímicas, de isótopos estables y geocronológicos de afloramientos basamentales de áreas aledañas a Los Humeros y Acoculco, Pue." to GEOMINCO S.A. de C.V. Additional funding was provided by the Instituto de Geología UNAM and the Centro de Geociencias UNAM through personal allocations. The radiogenic isotope determinations were carried out at the Centro de Geociencias UNAM with the assistance of Ofelia Pérez Arvizu and Carlos Ortega Obregón. The thin sections were elaborated by Juan Tomás Vázquez Ramírez of the Centro de Geociencias UNAM. FRX determinations were carried out at the Laboratorio Nacional de Geoquímica y MineralogíaInstituto de Geología UNAM with the assistance of Rufino Lozano Santacruz. The separation of zircon crystals was carried out with the assistance of Teodoro Hernández Treviño of the Instituto de Geofísica UNAM. Assistance during field work was provided by Jesús Castro and Dunia Figueroa. Also, Figure 1 was drawn with the assistance of Rodrigo Delgado Sánchez. The authors are also grateful to Carl Nelson, Lisard Torró and Joaquín Proenza, the guest editors of the present special issue, and to three anonymous referees, whose comments helped to significantly improve this manuscript.

\section{References}

Besch, T., Negendank, J., Emmermann, R., 1988, Geochemical constraints on the origin of the calc-alkaline and alkaline magmas of the eastern Trans-Mexican Volcanic Belt: Geofísica Internacional, 27, 641-663.

Birck, J. L.,1986, Precision K-Rb-Sr isotopic analysis: application to $\mathrm{Rb}-\mathrm{Sr}$ chronology: Chemical geology, 56(1-2), 73-83. https:// doi.org/10.1016/0009-2541(86)90111-7

Camprubí, A., 2009, Major metallogenic provinces and epochs of Mexico: SGA News, 25, 1-21. https://e-sga.org/fileadmin/sga/ newsletter/news25/SGANews25.pdf

Camprubí, A., 2013, Tectonic and metallogenic history of Mexico, in Colpron, M., Bissig, T., Rusk, B.G., Thompson, J.F.H., (eds.), Tectonics, metallogeny, and discovery: the North American Cordillera and similar accretionary settings: Littleton, Colorado, USA, Society of Economic Geologists. Society of Economic Geologists Special Publication, 17, 201-243. https://doi. org/10.5382/SP.17.06

Camprubí, A., 2017, The metallogenic evolution in Mexico during the Mesozoic, and its 
bearing in the Cordillera of Western North America. Ore Geology Reviews, 81, 1193-1214. https://doi.org/10.1016/j. oregeorev.2015.11.007

Camprubí, A., González-Partida, E., 2017, Mesozoic magmatic-hydrothermal iron oxide deposits (IOCG 'clan') in Mexico: Ore Geology Reviews, 81, 1084-1095. https:// doi.org/10.1016/j.oregeorev.2015.11.025

Camprubí, A., González-Partida, E., Valencia, V.A., Barra, F., 2015, Geochronology of Mexican mineral deposits. I: the San Martín polymetallic skarn, Zacatecas: Boletín de la Sociedad Geológica Mexicana, 67, 119-122. http://dx.doi.org/10.18268/ BSGM2015v67n1a10

Camprubí, A., Albinson, T., Iriondo, A., 2016a, Geochronology of Mexican mineral deposits. $\mathrm{V}$ : the Peñón Blanco epithermal deposit, Durango: Boletín de la Sociedad Geológica Mexicana, 68, 365-370. http://dx.doi. org/10.18268/BSGM2016v68n2a13

Camprubí, A., Iriondo, A., Martínez-López, M., Ramos-Rosique, A., 2016b, Geochronology of Mexican mineral deposits. IV: the Cinco Minas epithermal deposit, Jalisco: Boletín de la Sociedad Geológica Mexicana, 68, 357-364. http://dx.doi.org/10.18268/ BSGM2016v68n2a12

Camprubí, A., González-Partida, E., Alfonso, P., López-Martínez, M., Iriondo, A., CienfuegosAlvarado, E., Gutiérrez-Armendáriz, E., Morales-Puente, P., Canet, C., GonzálezRuiz, L., 2017, The Late Cretaceous Guaynopa IOCG and Guaynopita porphyry copper deposits, Chihuahua, Mexico. Ore Geology Reviews, 81, 1096-1112. https:// doi.org/10.1016/j.oregeorev.2016.01.006

Camprubí, A., Centeno-García, E., Tolson, G., Iriondo, A., Ortega, B., Bolaños, D., Abdullin, F., Portugal-Reyna, J.L., Ramos-Arias, M.A., 2018, Geochronology of Mexican mineral deposits. VII: the Peña Colorada magmatichydrothermal iron oxide deposit (IOCG "clan"), Colima: Boletín de la Sociedad
Geológica Mexicana, 70, 633-674. http:// dx.doi.org/10.18268/BSGM2018v70n3a4

Camprubí, A., Cabrera-Roa, M.A., GonzálezPartida, E., Martínez-López, M., 2019, Geochronology of Mexican mineral deposits. VIII: the Zacatepec polymetallic skarn, Oaxaca: Boletín de la Sociedad Geológica Mexicana, 71, 207-218. http://dx.doi. org/10.18268/BSGM2019v71nlal1

Camprubí, A., Fuentes-Guzmán, E., Gabites, J., Ortega-Larrocea, P., Colín-García, M., González-Partida, E., 2020, The Pliocene Ixtacamaxtitlán low sulfidation epithermal deposit (Puebla, Mexico): A case of fossil fungi consortia in a steam-heated environment:Boletín delaSociedad Geológica Mexicana, 72(3), A140420. http://dx.doi. org/10.18268/BSGM2020v72n3a140420

Cantagrel, J.M., Robin, C., 1979, K-Ar dating on eastern Mexican volcanic rocks - relations between the andesitic and the alkaline provinces: Journal of Volcanology and Geothermal Research, 5, 99-114. https:// doi.org/10.1016/0377-0273(79)90035-0

Carrasco-Nuñez, G., Bernal, J.P., Dávila, P., Jicha, B., Giordano, G., Hernández, J., 2018. Reappraisal of Los Humeros volcanic complex by new U/Th zircon and ${ }^{40} \mathrm{Ar} /{ }^{39} \mathrm{Ar}$ dating: Implications for greater geothermal potential: Geochemistry, Geophysics, Geosystems, 19, 132-149. https://doi. org/10.1002/2017GC007044

Castro-Mora, J., Hernández-Pérez, I., VélezLópez, J., Baca-Carreón, J. C., 1994 , Monografía Geológico-Minera del estado de Veracruz: Pachuca, Hidalgo, Consejo de Recursos Minerales.

Castro-Mora, J., Ortíz-Hernández, L.E., Escamilla-Casas, J.C., Cruz-Chávez, E., Dorantes-Castro, C.G., 2016, Metalogénesis de la mineralización tipo IOCG relacionada al skarn del Distrito Minero Las Minas, Estado de Veracruz: Tópicos de Investigación en Ciencias de la Tierra y Materiales, 3, 128-143. 
Centeno-García, E., 2017, Mesozoic tectonomagmatic evolution of Mexico: An overview: Ore Geology Reviews, 81, 1035-1052.https:// doi.org/10.1016/j.oregeorev.2016.10.010

Chen, J.-L., Xu, J.-F., Ren, J.-B., Huang, X.-X., Wang, B.-D., 2014, Geochronology and geochemical characteristics of Late Triassic porphyritic rocks from the Zhongdian arc, eastern Tibet, and their tectonic and metallogenic implications: Gondwana Research, 26, 492-504. https://doi. org/10.1016/j.gr.2013.07.022

Chiaradia, M., Fontboté, L., Beate, B., 2004, Cenozoic continental arc magmatism and associated mineralization in Ecuador: Mineralium Deposita, 39, 204-222. https:// doi.org/10.1007/s00126-003-0397-5

Clark, K.F., Fitch, D.C., 2009, Evolución de depósitos metálicos en tiempo y espacio en Mexico, in Clark, K.F., Salas-Pizá, G., Cubillas-Estrada, R., eds., Geología Económica de México, II Edición: Pachuca, Hidalgo, Servicio Geológico Mexicano, 62-133.

Cox, K.G., Bell, J.D., Pankhurst, R.J., 1979, The interpretation of igneous rocks: Boston, USA, George Allen and Unwin, 459 p.

Defant, M.J., Drummond, M.S., 1990, Derivation of some modern arc magmas by melting of young subducted lithosphere: Nature, 347, 662-665. https://doi.org/10.1038/347662a0

Defant, M.J., Xu, J.F., Kepezhinskas, P., Wang, Q., Zhang, Q., Xiao, L., 2002, Adakites: Some variations on a theme: Acta Petrologica Sinica, 18, 129-142.

Demant, A., and Robin, C., 1975, Las fases del volcanismo en Mexico; una sintesis en relacion con la evolucion geodinamica desde el Cretacico: Revista - Instituto de Geologia UNAM, Mexico, D.F., Mexico, v. I, p. 70-82.

Deng, J., Wang, Q., Li, G., 2017, Tectonic evolution, superimposed orogeny, and composite metallogenic system in China: Gondwana Research, 50, 216-266. https:// doi.org/10.1016/j.gr.2017.02.005
DePaolo, D.J., Wasserburg, G.J., 1979a, Petrogenetic mixing models and $\mathrm{Nd}-\mathrm{Sr}$ isotopic patterns: Geochimica et Cosmochimica Acta, 43, 615-627. https:// doi.org/10.1016/0016-7037(79)90169-8

DePaolo, D.J., Wasserburg, G.J., 1979b, Sm-Nd age of the Stillwater complex and the mantle evolution curve for neodymium: Geochimica et Cosmochimica Acta, 43, 999-1008. https:// doi.org/10.1016/0016-7037(79)90089-9

Dorantes-Castro, G.G., 2016, Características petrológicas y geoquímicas de los intrusivos relacionados a la mineralización y paragénesis del skarn tipo IOCG en la zona minera de Las Minas, estado de Veracruz: Instituto Politécnico Nacional, unpublished BSc thesis, $120 \mathrm{p}$.

Drummond, M.S., Defant, M.J., 1990, A model for trondhjemite-tonalite-dacite genesis and crustal growth via slab melting: Archaean to modern comparisons: Journal of Geophysical Research, 95, 21503-21521. https://doi. org/10.1029/JB095iB13p21503

Enríquez, E., Iriondo, A., Camprubí, A., 2018, Geochronology of Mexican mineral deposits. VI: the Tayoltita low-sulfidation epithermal district, Durango and Sinaloa: Boletín de la Sociedad Geológica Mexicana, 70, 531-547. http://dx.doi.org/10.18268/ BSGM2018v70n2a13

Farfán-Panamá, J.L., Camprubí, A., GonzálezPartida, E., Iriondo, A., González-Torres, E.A., 2015, Geochronology of Mexican mineral deposits. III: the Taxco epithermal deposit, Guerrero: Boletín de la Sociedad Geológica Mexicana, 67, 357-366. http:// dx.doi.org/10.18268/BSGM2015v67n2a16

Feeley, T.C., Davidson, J.P., 1994, Petrology of calc-alkaline lavas at Volcán Ollagüe and the origin of compositional diversity at Central Andean stratovolcanoes: Journal of Petrology, 35, 1295-1340. https://doi. org/10.1093/petrology/35.5.1295

Ferrari, L., Rosas-Elguera, J., 1999, Late Miocene to Quaternary extension at the northern 
boundary of the Jalisco block, western Mexico: the Tepic-Zacoalco rift revised, in Delgado-Granados, H., Stock, J., AguirreDíaz, G.J. (eds.), Cenozoic tectonics and volcanism of Mexico. Geological Society of America Special Paper, 334, 42-64. https:// doi.org/10.1130/0-8137-2334-5.41

Ferrari, L., Tagami, T., Eguchi, M., OrozcoEsquivel, M.T., Petrone, C.M., JacoboAlbarrán, J., López-Martínez, M., 2005a, Geology, geochronology and tectonic setting of late Cenozoic volcanism along the southwestern Gulf of Mexico: The Eastern Alkaline Province revisited: Journal of Volcanology and Geothermal Research, 146, 284-306. https://doi.org/10.1016/j. jvolgeores.2005.02.004

Ferrari, L., Valencia-Moreno, M., Bryan, S., 2005b, Magmatismo y tectónica en la Sierra Madre Occidental y su relación con la evolución de la margen occidental de Norteamérica: Boletín de la Sociedad Geológica Mexicana, 57, 343-378. http://dx.doi.org/10.18268/ BSGM2005v57n3a5

Ferrari, L., Valencia-Moreno, M., Bryan, S., 2007, Magmatism and tectonics of the Sierra Madre Occidental and its relation with the evolution of the western margin of North America, in Alaniz-Álvarez, S.A., NietoSamaniego, Á.F. (eds.), Geology of México: Celebrating the Centenary of the Geological Society of México: Geological Society of America Special Paper, 422, 1-39. https:// doi.org/10.1130/2007.2422(01)

Fitz-Díaz, E., Lawton, T.F., Juárez-Arriaga, E., Chávez-Cabello, G., 2018, The CretaceousPaleogene Mexican orogen: Structure, basin development, magmatism and tectonics: Earth-Science Reviews, 183, 56-84. https:// doi.org/10.1016/j.earscirev.2017.03.002

Frost, B.R., Barnes, G.G., Collins, W.J., Arculus, R.J., Ellis, D.J., Frost, G.D., 2001, A geochemical classification for granitic rocks: Journal of Petrology, 42 (11), 2033-2048. https://doi. org/10.1093/petrology/42.11.2033
Fuentes-Guzmán, E., Camprubí, A., Gabites, J., González-Partida, E., 2020, The Pliocene Xoconostle high sulfidation epithermal deposit in the Trans-Mexican Volcanic Belt:Preliminary study: Boletín de la Sociedad Geológica Mexicana, 72(3), A260520. http://dx.doi.org/10.18268/ BSGM2020v72n3a260520

Gatzoubaros, M., von Quadt, A., Gallhofer, D., Rey, R., 2014, Magmatic evolution of pre-ore volcanics and porphyry intrusives associated with the Altar Cu-porphyry prospect, Argentina: Journal of South American Earth Sciences, 55, 58-82. https://doi. org/10.1016/j.jsames.2014.06.005

Gómez-Tuena, A., La Gatta, A., Langmuir, C., Goldstein, S., Ortega-Gutiérrez, F., Carrasco-Núñez, G., 2003, Temporal control of subduction magmatism in the Eastern Trans-Mexican Volcanic Belt: mantle sources, slab contributions and crustal contamination: Geochemistry, Geophysics, Geosystems, 4 (8), 8912. https://doi. org/10.1029/2003GC000524

Gómez-Tuena, A., Orozco-Esquivel, M.T., Ferrari, L., 2005, Petrogénesis ígnea de la Faja Volcánica Transmexicana: Boletín de la Sociedad Geológica Mexicana, 57, 227-283. http://dx.doi.org/10.18268/ BSGM2005v57n3a2

Gómez-Tuena, A., Orozco-Esquivel, M.T., Ferrari, L., 2007, Igneous petrogenesis of the TransMexican Volcanic Belt, in Alaniz-Álvarez, S.A., Nieto-Samaniego, Á.F., eds., Geology of México: Celebrating the centenary of the Geological Society of México: Boulder, Colorado, USA, The Geological Society of America. Geological Society of America Special Paper, 422, 129-182. https://doi. org/10.1130/2007.2422(05)

González-Jiménez, J.M., Camprubí, A., Colás, V., Griffin, W.L., Proenza, J.A., Belousova, E., Centeno-García E., O’Reilly, S.Y., Talavera, G., Farré-de-Pablo, J., Satsukawa, T., 2017a, The recycling of chromitites in ophiolites 
from southwestern North America: Lithos, 294-295, 53-72. https://doi.org/10.1016/j. lithos.2017.09.020

González-Jiménez, J.M., Proenza, J.A., Martini, M., Camprubí, A., Griffin, W.L., O’Reilly, S.Y., Pearson, N.J., 2017b, Deposits associated with ultramafic-mafic complexes in Mexico: the Loma Baya case: Ore Geology Reviews, 81, 1053-1065. https://doi.org/10.1016/j. oregeorev.2015.05.014

González-León, G.M., Solari, L., ValenciaMoreno, M., Rascon Heimpel, M.A., Solé, J., González Becuar, E., Lozano Santacruz, R., Pérez Arvizu, O., 2017, Late Cretaceous to early Eocene magmatic evolution of the Laramide arc in the Nacozari quadrangle, northeastern Sonora, Mexico and its regional implications: Ore Geology Reviews, 81, 1137-1157. https://doi.org/10.1016/j. oregeorev.2016.07.020

González-Partida, E., Levresse, G., CarrilloChávez, A., Cheilletz, A., Gasquet, D., Jones, D., 2003a, Paleocene adakite Au-Fe bearing rocks, Mezcala, Mexico: Evidence from geochemical characteristics: Journal of Geochemical Exploration, 80, 25-40. https:// doi.org/10.1016/S0375-6742(03)00180-8

González-Partida, E., Levresse, G., CarrilloChávez, A., Cheilletz, A., Gasquet, D., Solorio-Munguía, J., 2003b, (Au-Fe) skarn deposits of the Mezcala district, SouthCentral Mexico: Adakite association of the mineralizing fluids: International Geology Review, 45, 79-93. https://doi. org/10.2747/0020-6814.45.1.79

Gutscher, M.A., Maury, R., Eissen, J.P., Bourdon, E., 2000, Can slab melting be caused by flat subduction?: Geology, 28(6), 535-538.https:// doi.org/10.1130/0091-7613(2000)28<535:CS $\mathrm{MBCB}>2.0 . \mathrm{CO} ; 2$

Hoffman, A.W., White, W.M., 1982, Mantle plumes fromancientoceaniccrust:EarthandPlanetary Science Letters, 57, 421-436. https://doi. org/10.1016/0012-821X(82)90161-3

Iriondo, A., Kunk, M.J., Winick, J.A., CRM, 2003, ${ }^{40} \mathrm{Ar} /{ }^{39} \mathrm{Ar}$ dating studies of minerals and rocks in various areas in Mexico: USGS/ CRM Scientific Collaboration: Part I: USGS Open File Report 03-020, online edition, 79 p. https://doi.org/10.3133/ofr0320

Irvine, T., Baragar, W., 1971, A guide to the chemical classification of the common volcanic rocks: Canadian Journal of Earth Sciences, 8, 523-548. https://doi. org/10.1139/e71-055

Jansen, N.H., Gemmell, J.B., Chang, Z., Cooke, D.R., Jourdan, F., Creaser, R.A., Hollings, P., 2017, Geology and genesis of the Cerro la Mina porphyry-high sulfidation $\mathrm{Au}(\mathrm{Cu}-$ Mo) prospect, Mexico: Economic Geology, 112, 799-827. http://dx.doi.org/10.2113/ econgeo.112.4.799

Kay, S.M., Mpodozis, C., Coira, B., 1999, Neogene magmatism, tectonism, and mineral deposits of the Central Andes $\left(22^{\circ}\right.$ to $33^{\circ} \mathrm{S}$ latitude): Society of Economic Geologists, Special Publication, 7, 27-59. https://doi. org/10.5382/SP.07.02

Keevil, H.A., Monecke, T., Goldfarb, R.J., Möller, A., Kelly, N.M., 2019, Geochronology and geochemistry of Mesozoic igneous rocks of the Hunjiang basin, Jilin Province, NE China: Constraints on regional tectonic processes and lithospheric delamination of the eastern North Ghina block: Gondwana Research, 68, 127-157. https://doi.org/10.1016/j. gr.2018.11.010

Keppie, J.D., Morán-Zenteno, D.J., 2005, Tectonic implications of alternative Cenozoic reconstructions for southern Mexico and the Chortis Block: International Geology Review, 47, 473-491. https://doi. org/10.2747/0020-6814.47.5.473

Kirsch, M, Keppie, J.D., Murphy, J.B., Solari, L., 2012, Permian-Carboniferous arc magmatism basin evolution along the western margin of Pangea: geochemical and geochronological evidence from the eastern Acatlán Complex, southern Mexico: Geological Society of America Bulletin, 124, 1607-1628. https://doi.org/10.1130/ B30649.1 
Klepeis, K.A., Clarke, G.L., Rushmer, T., 2003, Magma transport and coupling between deformation and magmatism in the continental lithosphere: GSA Today, 13, 4-11. https://www.geosociety.org/gsatoday/ archive/13/1/pdf/i1052-5173-13-1-4.pdf

Kuiper, K.F., Deino, A., Hilgen, F.J., Krijgsman, W., Renne, P.R., Wijbrans, J.R., 2008, Synchronizing rock clocks of Earth history: Science, 320, 500-504. https://doi. org/10.1126/science.1154339

Liu, D., Zhao, Z., DePaolo, D.J., Zhu, D.-C., Meng, F.-Y., Shi, Q., Wang, Q., 2017, Potassic volcanic rocks and adakitic intrusions in southern Tibet: Insights into mantle-crust interaction and mass transfer from Indian plate: Lithos, 268-271, 48-64. https://doi. org/10.1016/j.lithos.2016.10.034

Lohmeier, S., Schneider, A., Belyatsky, B., Lehmann, B., 2019, Magmatic evolution of the Cerro Maricunga gold porphyryepithermal system, Maricunga belt, N-Chile: Journal of South American Earth Sciences, 92, 374-399. https://doi.org/10.1016/j. jsames.2019.03.003

Lozano-Santa Cruz, R., Verma, S.P., Girón, P., Velasco-Tapia, F., Morán-Zenteno, D.J., Viera, F., Chávez, G., 1995, Calibración preliminar de fluorescencia de rayos X para análisis cuantitativo de elementos mayores en rocas ígneas: Actas INAGEQ, 1, 203-208.

López-Infanzón, M., 1991, Petrologic study of volcanic rocks from the ChiconquiacoPalma Sola area, Central Veracruz, Mexico: unpublished MSc thesis, Tulane University, New Orleans, Louisiana, USA, 140 p.

Lu, Y.-J., Kerrich, R., Mccuaig, T.C., Li, Z.-X., Hart, C.J.R., Cawood, P.A., Hou, Z.-Q., Bagas, L., Cliff, J., Belousova, E.A., Tang, S.-H., 2013, Geochemical, Sr-Nd-Pb, and zircon Hf-O isotopic compositions of eocene-oligocene shoshonitic and potassic adakite-like felsic intrusions in western Yunnan, SW China: Petrogenesis and tectonic implications: Journal of Petrology,
54, 1309-1348. https://doi.org/10.1093/ petrology/egt013

Ludwig, K.R., 2003,ISOPLOT, a geochronological toolkit for Microsoft Excel, Version 3.00: Berkeley Geochronology Center Special Publication, 4, $70 \mathrm{p}$.

Macpherson, G.G., Dreher, S.T., Thirlwall, M.F., 2006, Adakites without slab melting: High pressure differentiation of island arc magma, Mindanao, the Philippines: Earth and Planetary Science Letters, 243, 581-593. https://doi.org/10.1016/j.epsl.2005.12.034

Ma, Q., Zheng, J.P., Xu, Y.-G., Griffin, W.L., Zhang, R.-S., 2015, Are continental "adakites" derived from thickened or foundered lower crust?: Earth and Planetary Science Letters, 419, 125-133. https://doi.org/10.1016/j. epsl.2015.02.036

Martin, H., 1986, Effect of steeper Archaean geothermal gradient on geochemistry of subduction zone magmas: Geology, 14, 753-756. https://doi.org/10.1130/0091$7613(1986) 14<753:$ EOSAGG $>2.0$. $\mathrm{CO} ; 2$

Martin, H., Moyen, J.-F., 2002, Secular changes in TTG composition as markers of the progressive cooling of the Earth: Geology, 30 (4), 319-322. https://doi.org/10.1130/0091$7613(2002) 030<031$ 9:SGITTG > 2.0. $\mathrm{CO} ; 2$

Martin, H., Moyen, J.-F., 2003, Secular changes in TTG composition: comparison with modern adakites: EGS-AGU-EUG Joint Meeting, Nice, April, VGP7-1FR2O-001, abstract 2673. http://adsabs.harvard.edu/ abs/2003EAEJA.....2673M

Martin, H., Smithies, R.H., Rapp, R., Moyen, J.-F., Champion, D., 2005, An overview of adakite, tonalite-trondhjemite-granodiorite (TTG), and sanukitoid: relationships and some implications for crustal evolution: Lithos, 79 (1-2), 1-24. https://doi.org/10.1016/j. lithos.2004.04.048

Martínez-Reyes, J.J., Camprubí, A., Uysal, I.T., Iriondo, A., González-Partida, E., 2015, 
Geochronology of Mexican mineral deposits. II: Veta Madre and Sierra epithermal vein systems, Guanajuato district: Boletín de la Sociedad Geológica Mexicana, 67, 349-355. http://dx.doi.org/10.18268/ BSGM2015v67n2a15

Martini, M., Ortega-Gutiérrez, F., 2018, Tectonostratigraphic evolution of eastern Mexico during the break-up of Pangea: A review: Earth-Science Reviews, 183, 38-55. https:// doi.org/10.1016/j.earscirev.2016.06.013

Masliwec, A., 1984, Applicability of the ${ }^{40} \mathrm{Ar} /{ }^{39} \mathrm{Ar}$ method to the dating of ore bodies: Unpublished $\mathrm{PhD}$ Dissertation. University of Toronto, Toronto, Ontario, Canada.

Meinert, L.D., 1995, Compositional variations of igneous rocks associated with skarn deposits chemical evidence for genetic connections between petrogenesis and mineralization, in Thompson, J.F.H. (ed.), Magmas, Fluids, and Ore Deposits: Mineralogical Association of Canada, Short Course Series, 23, 401-419.

Morán-Zenteno, D.J., Tolson, G., MartínezSerrano, R.G., Martiny, B., Schaaf, P., Silva-Romo, G., Macías-Romo, C., AlbaAldave, L., Hernández-Bernal, M.S., Solís-Pichardo, G.N., 1999, Tertiary arcmagmatism of the Sierra Madre del Sur, Mexico, and its transition to the volcanic activity of the Trans-Mexican Volcanic Belt: Journal of South American Earth Sciences, 12, 513-535. https://doi.org/10.1016/ S0895-981 1(99)00036-X

Mori, L., Gómez-Tuena, A., Cai, Y., Goldstein, S., 2007, Effects of prolonged flat subduction on the Miocene magmatic record of the central Trans-Mexican Volcanic Belt: Chemical Geology, 244, 452-473. https:// doi.org/10.1016/j.chemgeo.2007.07.002

Murillo-Muñetón, G., Torres-Vargas, R., 1987, Mapa petrogenético y radiométrico de la República Mexicana: Mexico City, Instituto Mexicano del Petróleo, Subdirección de Tecnología de Exploración, informe del proyecto C-2010, 78 p.

Negendank, J.F.W., Emmermann, R., Krawczyk, R., Mooser, F., Tobschall, H., Werle, D., 1985,
Geological and geochemical investigations on the eastern Trans Mexican Volcanic Belt: Geofísica Internacional, 24, 477-575.

Ortega-Obregón, C., Solari, L., Gómez-Tuena, A., Elías-Herrera, M., Ortega-Gutiérrez, F., Macías-Romo, G., 2013, PermianCarboniferous arc magmatism in southern Mexico: U-Pb dating, trace element and $\mathrm{Hf}$ isotopic evidence on zircons of earliest subduction beneath the western margin of Gondwana: International Journal of Earth Sciences, 103, 1287-1300. https://doi. org/0.1007/s00531-013-0933-1.

Ortuño-Arzate, S., Ferket, H., Cacas, M.C., Swennen, R., Roure, F., 2005, Late Cretaceous carbonate reservoirs in the Cordoba platform and Veracruz basin, eastern Mexico, in Bartolini, C., Buffler, R.T., Blickwede, J.F. (eds.), The circum-Gulf of Mexico and the Caribbean: Hydrocarbon habitats, basin formation and plate tectonics: AAPG Memoir, 79, 87-92. https://doi. org/10.1306/M79877C22

Orozco-Esquivel, M., Petrone, C., Ferrari, L., Tagami, T., Manetti, P., 2007, Geochemical and isotopic variability controlled by slab detachment in a subduction zone with varying dip: The eastern Trans-Mexican Volcanic Belt: Lithos, 93(1-2),149-174. https://doi. org/10.1016/j.lithos.2006.06.006

Pearce, J.A., Harris, N.B.W., Tindle, A.G., 1984, Trace element discrimination diagrams for the tectonic interpretation of granitic rocks: Journal of Petrology, 25, 956-983. https:// doi.org/10.1093/petrology/25.4.956

Poliquin, M.J., 2009, Geology, geochemistry and age of intrusion-related mineralisation in Eastern Mexico: Exeter, U.K., University of Exeter, unpublished $\mathrm{PhD}$ dissertation, 398 p.

Ribeiro, J., Maury, R.C., Grégoire, M., 2016, Are adakites slab melts or high-pressure fractionated mantle melts?: Journal of Petrology, 57, 1-24. https://doi. org/10.1093/petrology/egw023

Richards, J.P., 2011, High Sr/Y arc magmas and porphyry $\mathrm{Cu} \pm \mathrm{Mo} \pm \mathrm{Au}$ deposits: just add water: Economic Geology, 106, 
1075-1081. https://doi.org/10.2113/ econgeo.106.7.1075

Richards, J.P., Kerrich, R., 2007, Adakite-like rocks: Their diverse origins and questionable role in metallogenesis: Economic Geology, 102, 537-576. http://dx.doi.org/10.2113/ gsecongeo. 102.4.537

Richards, J.P., Mumin, A.H., 2013, Lithospheric Fertilization and Mineralization by Arc Magmas: Genetic Links and Secular Differences Between Porphyry Copper \pm Molybdenum \pm Gold and MagmaticHydrothermal Iron Oxide Copper-Gold Deposits, in Colpron, M., Bissig, T., Rusk, B.G., Thompson, J.F.H., (eds.), Tectonics, metallogeny, and discovery: the North American Cordillera and similar accretionary settings: Littleton, Colorado, USA, Society of Economic Geologists. Society of Economic Geologists Special Publication, 17, 277-299. https://doi.org/10.5382/SP.17.09

Rodríguez, G., Sellés, D., Dungan, M., Langmuir, C., Leeman, W., 2007, Adakitic dacites formed by intracrustal crystal fractionation of water-rich parent magmas at Nevado de Longavi volcano (36 2 S; Andean Southern Volcanic Zone, Central Chile): Journal of Petrology, 48, 2033-2061. https://doi. org/10.1093/petrology/egm049

Sarabia-Jacinto, L.O., 2017, Caracterización termo-barométrica de los fluidos mineralizantes de la mina El Dorado, del Distrito Minero de Tatatila-Las Minas, Veracruz: Universidad de Guanajuato, unpublished BSc thesis, $126 \mathrm{p}$.

Servicio Geológico Mexicano, 2007, Carta geológico-minera Perote E14-B26, Veracruz y Puebla, 1:50,000: Pachuca, Hidalgo, Mexico, Servicio Geológico Mexicano.

Servicio Geológico Mexicano, 2010, Carta geológico-minera Altotonga E14-B16, Veracruz y Puebla, 1:50,000: Pachuca, Hidalgo, Mexico, Servicio Geológico Mexicano.

Solari, L.A., Tanner, M., 2011, UPb.age, a fast data reduction script for LA-ICP-MS
$\mathrm{U}-\mathrm{Pb}$ geochronology: Revista Mexicana de Ciencias Geológicas, 28, 83-91. http://satori. geociencias.unam.mx/28-1/(06)Solari.pdf

Solari, L.A., Gómez-Tuena, A., Bernal, J.P., PérezArvizu, O., Tanner, M., 2010, U-Pb zircon geochronology by an integrated LA-ICPMS microanalytical workstation: achievements in precision and accuracy: Geostandard and Geoanalytical Research, 34, 5-18. https:// doi.org/10.1111/j.1751-908X.2009.00027.x

Sun, S.-S., McDonough, W.E., 1989, Chemical and isotopic systematics of oceanic basalts: implications for mantle composition and processes: Geological Society, London, Special Publication, 42, 313-345. https:// doi.org/10.1144/GSL.SP.1989.042.01.19

Steiger, R.H., Jäger, E., 1977, Subcommission on Geochronology: Convention on the use of decay constants in Geo and Cosmochronology: Earth and Planetary Science Letters, 36, 359-362. https://doi. org/10.1016/0012-821X(77)90060-7

Sun, W., Zhang, H., Ling, M.-X., Ding, X., Chung, S.-L., Zhou, J., Yang, X.-Y., Fan, W., 2011 , The genetic association of adakites and $\mathrm{Cu}-\mathrm{Au}$ ore deposits: International Geology Review, 53, 691-703. https://doi.org/10.10 80/00206814.2010.507362

Sun, X., Lu, Y.-J., McCuaig, T.C., Zheng, Y.Y., Chang, H.-F., Guo, F., Xu, L.-J., 2018, Miocene ultrapotassic, high-Mg dioritic, and adakite-like rocks from Zhunuo in Southern Tibet: Implications for mantle metasomatism and porphyry copper mineralization in collisional orogens: Journal of Petrology, 59, 341-386. https://doi.org/10.1093/ petrology/egy028

Thirlwall, M.F., Smith, T.E., Graham, A.M., Theodorou, N., Hollings, P., Davidson, J.P., Arculus, R.D., 1994, High field strength element anomalies in arc lavas: Source or processes?: Journal of Petrology, 35, 819-838. https://doi.org/10.1093/ petrology/35.3.819

Todt, W., Cliff, R., Hanser A., Hofmann A.W., 1996, Evaluation of a ${ }^{202} \mathrm{pb} \_{ }^{205} \mathrm{pb}$ Double Spike 
for High-Precision Lead Isotope Analysis. A. Basu, S. Hart (Eds.): Earth Processes: Reading the Isotopic Code, Geophys. Monogr., vol. 95, AGU, Washington D.C., pp. 429-437.

Viniegra, F., 1965, Geología del Macizo de Teziutlán y de la cuenca cenozoica de Veracruz: Boletín de la Asociación Mexicana de Geólogos Petroleros, 17, 7-12.

Whalen, J.B., Currie, K.J., Chappell, B.W., 1987, A-type granites: geochemical characteristics, discrimination and petrogenesis: Contributions to Mineralogy and Petrology, 95, 407-419. https://doi.org/10.1007/BF00402202
York, D., Evensen, N.M., López-Martínez, M., De Basabe-Delgado, J., 2004, Unified equations for the slope, intercept, and standard errors of the best straight line: American Journal of Physics, 73 (3), 367-375. https://doi. org/10.1119/1.1632486

Zhang, L., Hu, Y., Liang, J., Ireland, T., Chen, Y., Zhang, R., Sun, S., Sun, W., 2017, Adakitic rocks associated with the Shilu coppermolybdenum deposit in the Yangchun Basin, South China, and their tectonic implications: Acta Geochimica, 36, 132-150. https://doi. org/10.1007/s11631-017-0146-6 

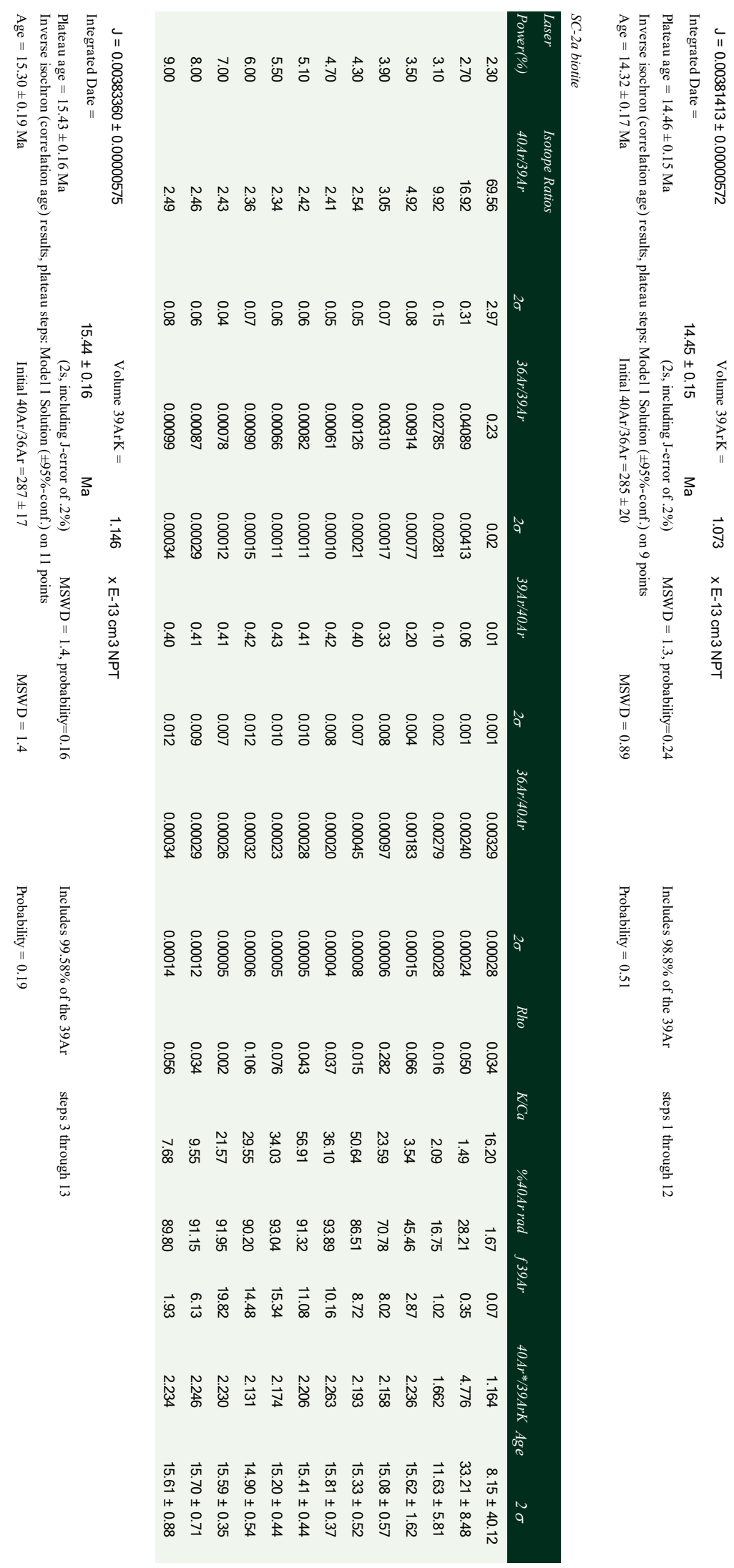

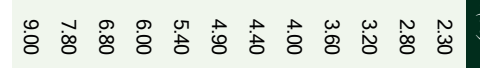

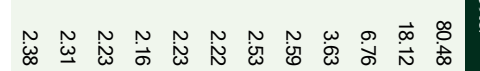

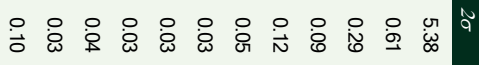

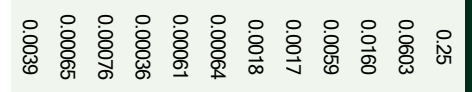

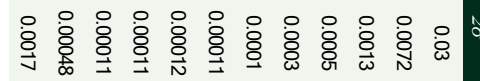

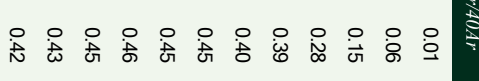

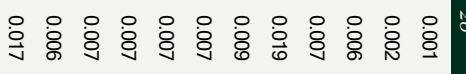

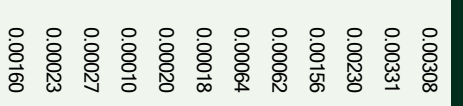

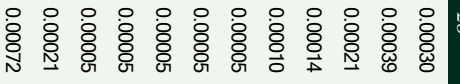

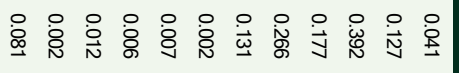

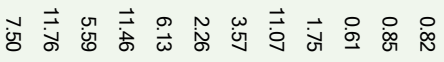

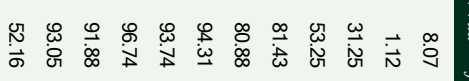

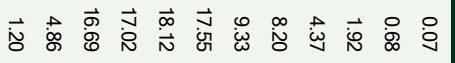

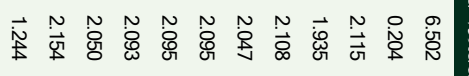

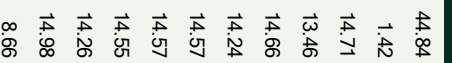

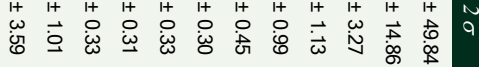




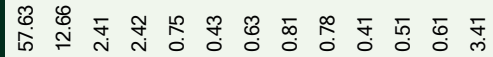

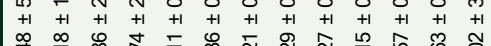

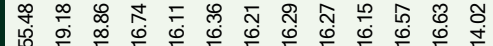

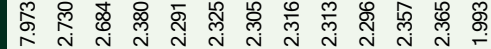

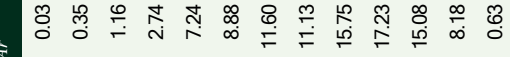

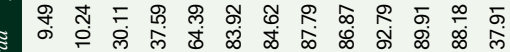

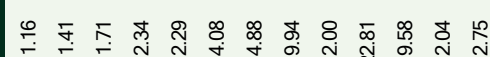

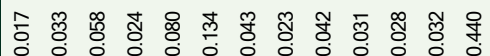

ర్

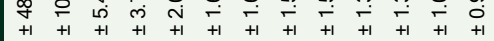

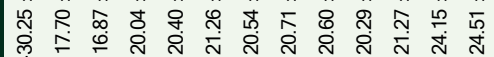

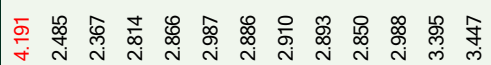

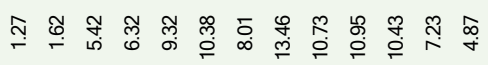

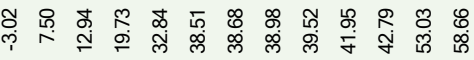

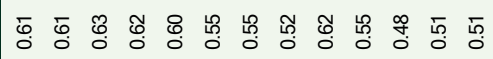

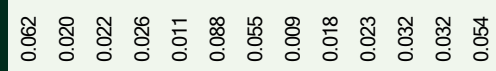

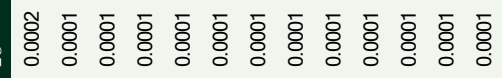



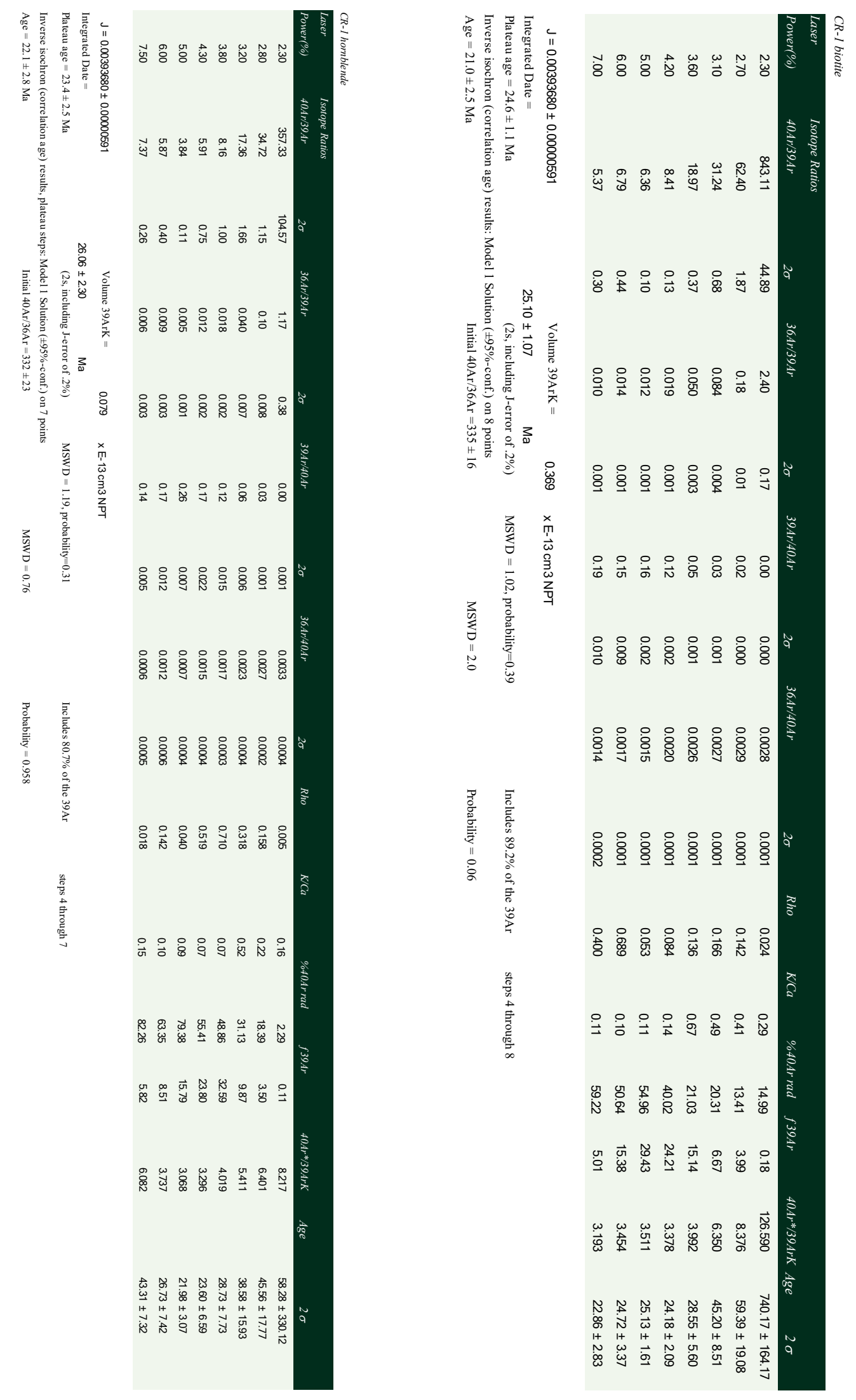

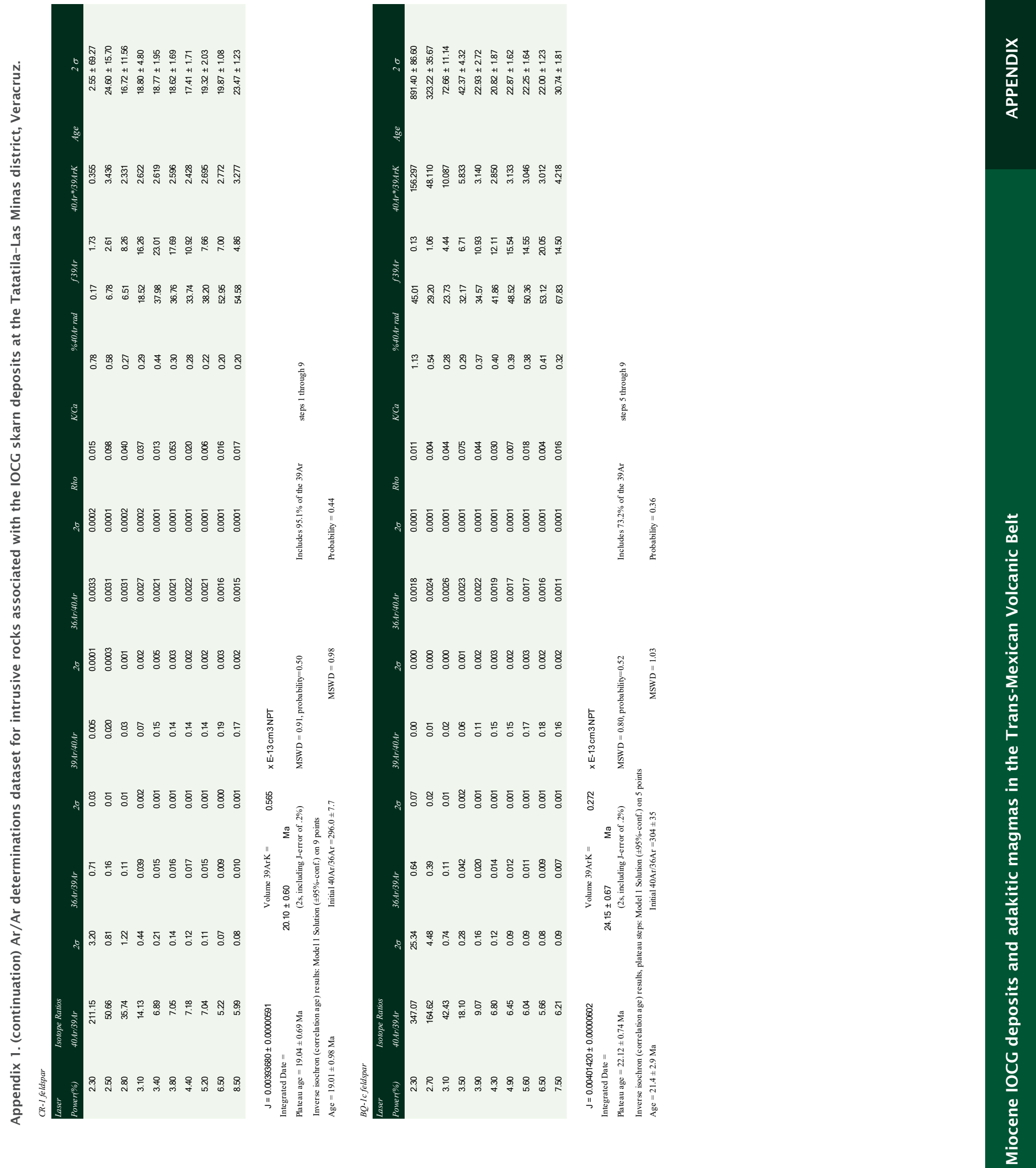

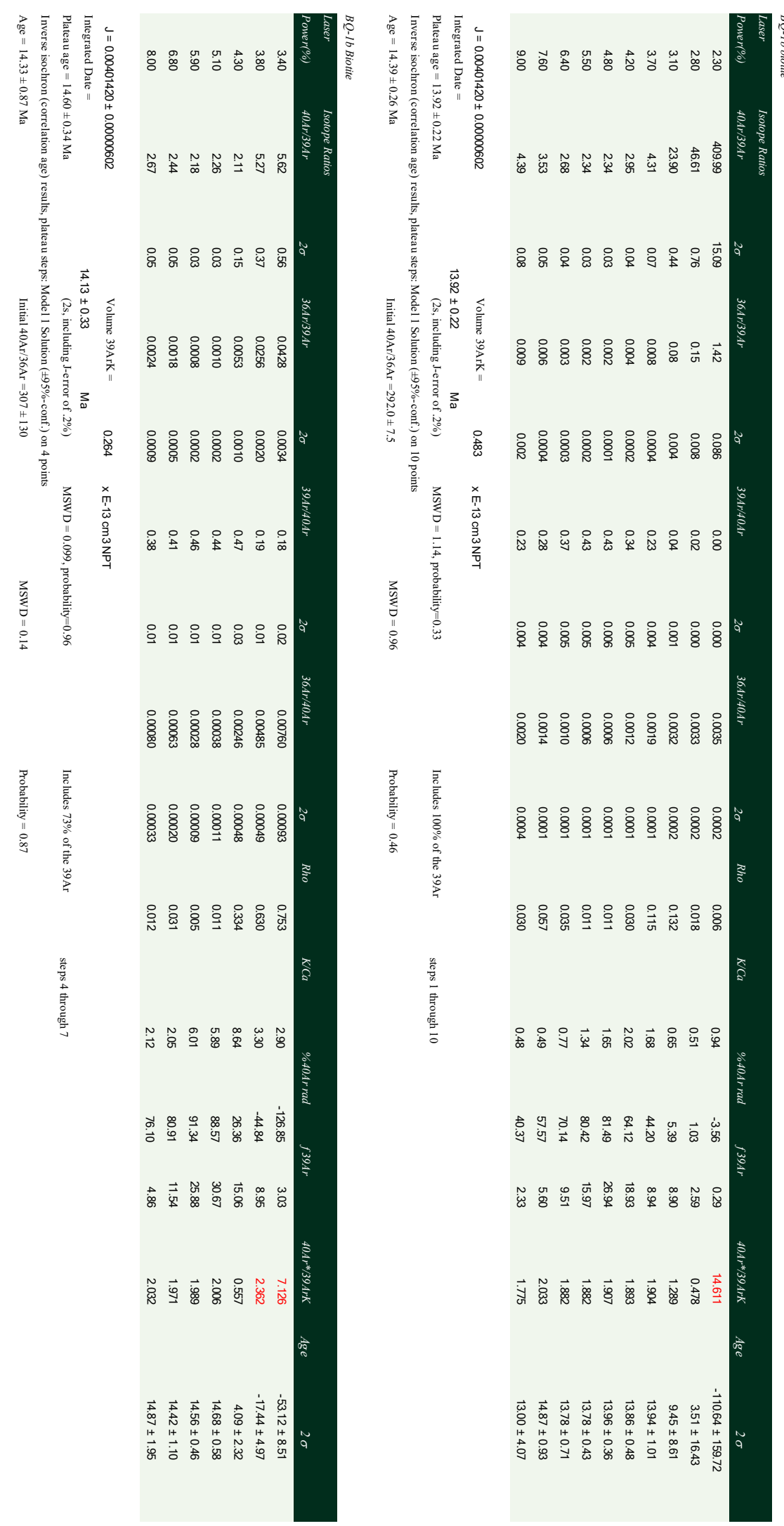
Appendix 1. (continuation) Ar/Ar determinations dataset for intrusive rocks associated with the IOCG skarn deposits at the Tatatila-Las Minas district, Veracruz.

\section{FSC-1 Fuchsita}

\begin{tabular}{|c|c|c|c|c|c|c|c|c|c|c|}
\hline Pwr & ${ }^{39} \mathrm{Ar} \times 10^{-6}$ & $\%{ }^{39} \mathrm{Ar}$ & ${ }^{40} \mathrm{Ar}^{*} /{ }^{39} \mathrm{Ar}_{\mathrm{K}}$ & $1 \sigma$ & Age in $\mathrm{Ma}$ & $1 \sigma$ & & $\%{ }^{40} \mathrm{Ar}^{*}$ & ${ }^{40} \mathrm{Ar} /{ }^{36} \mathrm{Ar}$ & ${ }^{37} \mathrm{Ar}_{\mathrm{Ca}}{ }^{\prime 39} \mathrm{Ar}_{\mathrm{K}}$ \\
\hline 0.6 & 0.668 & 0.08 & 33.6 & 12.03 & 140.99 & 48.56 & $\mathrm{a}$ & 23.27 & 385.11 & 0.003 \\
\hline 1.5 & 4.769 & 0.57 & 2.57 & 2.18 & 11.18 & 9.47 & $\mathrm{~b}$ & 7.65 & 319.96 & 1.58 \\
\hline 2.2 & 14.443 & 1.74 & 0.39 & 0.76 & 1.71 & 3.3 & $\mathrm{c}$ & 1.68 & 300.54 & 0.044 \\
\hline 2.7 & 38.246 & 4.61 & 2.5 & 0.39 & 10.88 & 1.67 & d & 25.18 & 394.94 & 0.008 \\
\hline 3.4 & 43.922 & 5.3 & 3 & 0.18 & 13.04 & 0.77 & e & 55.38 & 662.25 & 0.003 \\
\hline 4 & 145.819 & 17.59 & 2.87 & 0.06 & 12.47 & 0.26 & $\mathrm{f}$ & 72.32 & 1067.62 & 0.006 \\
\hline 5 & 270.778 & 32.67 & 2.86 & 0.03 & 12.43 & 0.11 & g & 87.63 & 2388.74 & 0.004 \\
\hline 6 & 140.591 & 16.96 & 2.87 & 0.03 & 12.46 & 0.12 & $\mathrm{~h}$ & 95.72 & 6898.02 & $<0.001$ \\
\hline 8 & 169.7 & 20.47 & 2.88 & 0.03 & 12.51 & 0.13 & $\mathrm{i}$ & 96.36 & 8120.85 & $<0.001$ \\
\hline
\end{tabular}

Integrated results

\begin{tabular}{|ccccccccc|}
${ }^{39} \mathrm{Ar} \times 10^{-6}$ & ${ }^{40} \mathrm{Ar} *{ }^{39} \mathrm{Ar}_{\mathrm{K}}$ & $1 \sigma$ & Age in $\mathrm{Ma}$ & $1 \sigma$ & ${ }^{*}{ }^{40} \mathrm{Ar}^{*}$ & ${ }^{40} \mathrm{Ar}^{\beta 6} \mathrm{Ar} \quad{ }^{37} \mathrm{Ar}_{\mathrm{Ca}}$ \\
\hline 828.9 & 2.84 & 0.04 & 12.33 & 0.16 & 65.29 & 851.36 & 0.013 \\
\hline
\end{tabular}

$\mathrm{J}=0.002419 \pm 0.000010$

Plateau age $\quad \mathrm{t}_{\mathrm{p}}=12.49 \pm 0.09 \mathrm{Ma}$

Weighted mean of fractions e to i, representing $92.99 \%$ of ${ }^{39}$ Ar released in 5 consecutive fractions, MSWD $=0.18$

Isochron age

$$
\mathrm{t}_{\mathrm{c}}=12.45 \pm 0.11 \mathrm{Ma} ;\left({ }^{40} \mathrm{Ar}{ }^{36} \mathrm{Ar}\right)_{\mathrm{i}}=300 \pm 15, \mathrm{MSWD}=0.2 \text { for } \mathrm{n}=5 \text { (e to i) }
$$


Appendix 2. Plateau age spectra and normal isochron diagrams in host intrusive bodies to the IOCG skam deposits at the Tatatila-Las Minas district, Veracruz.
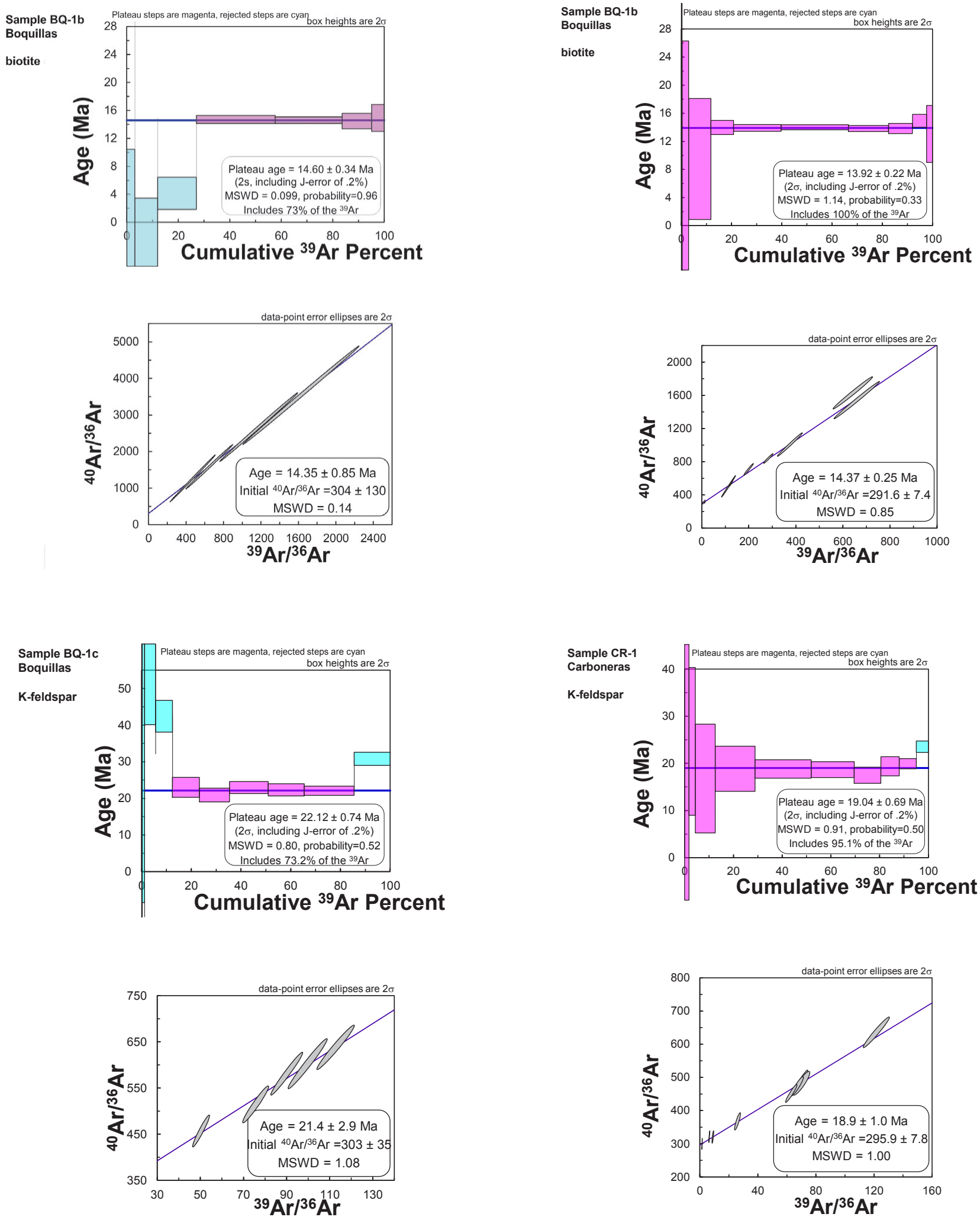
Appendix 2. (Continuation) Plateau age spectra and normal isochron diagrams in host intrusive bodies to the IOCG skam deposits at the Tatatila-Las Minas district, Veracruz.
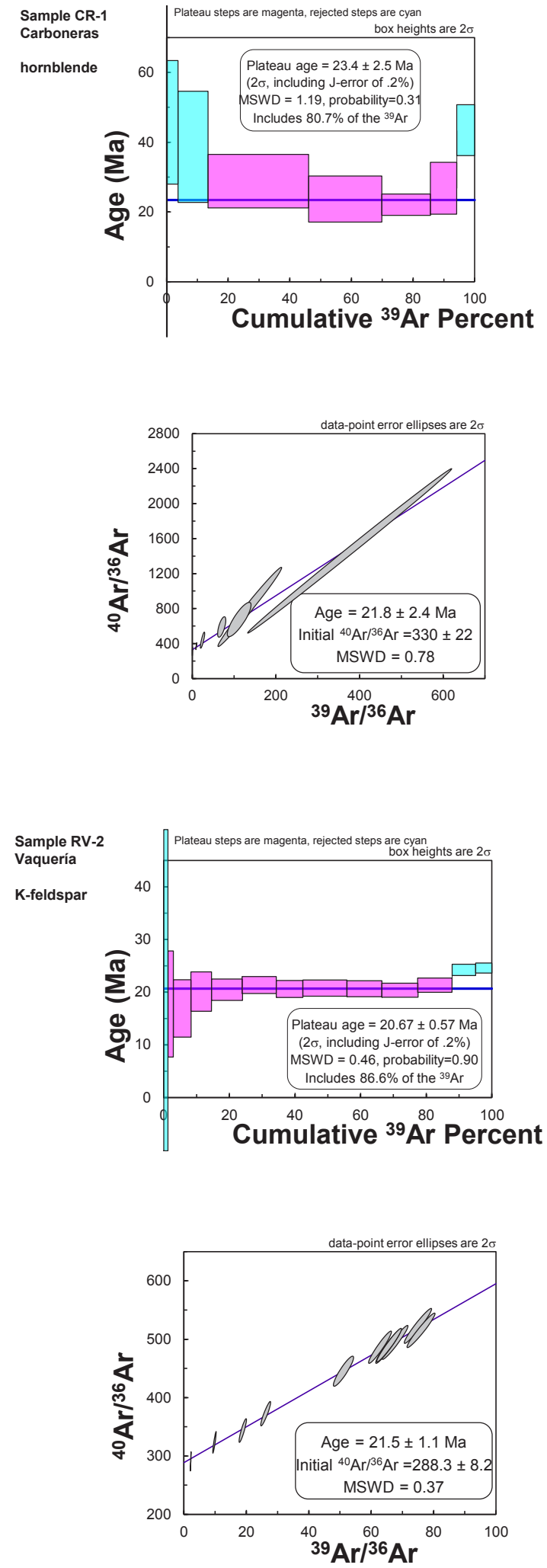
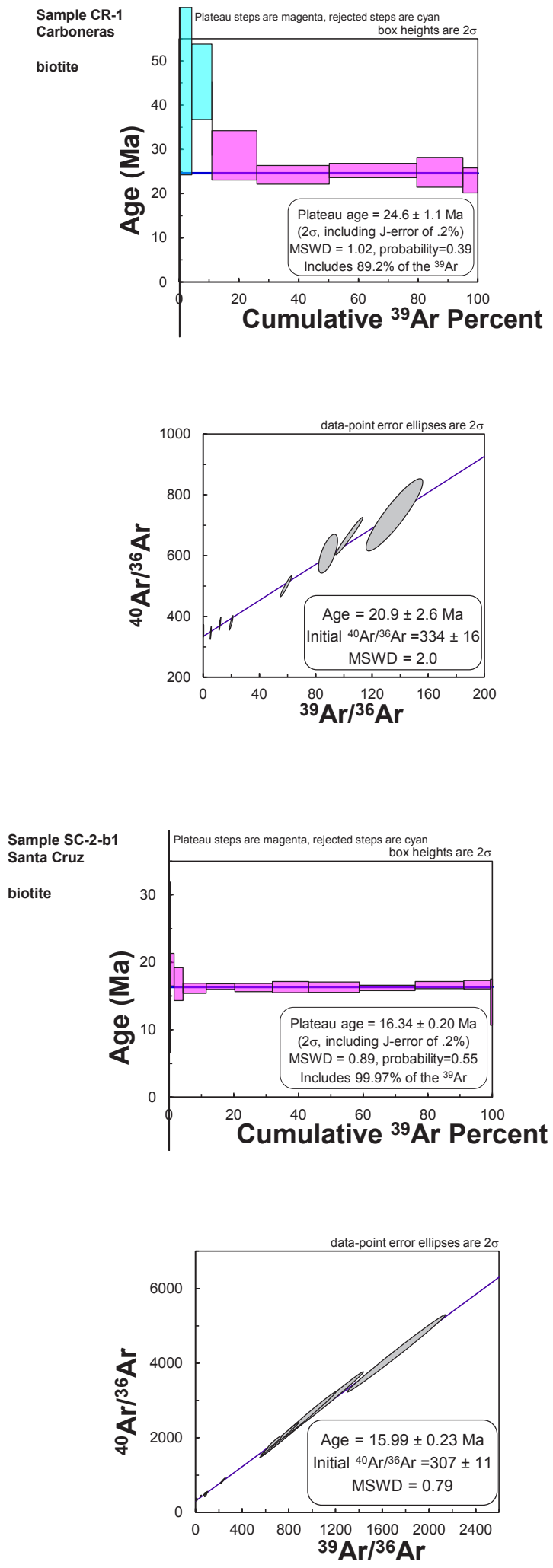
Appendix 2. (Continuation) Plateau age spectra and normal isochron diagrams in host intrusive bodies to the IOCG skam deposits at the Tatatila-Las Minas district, Veracruz.
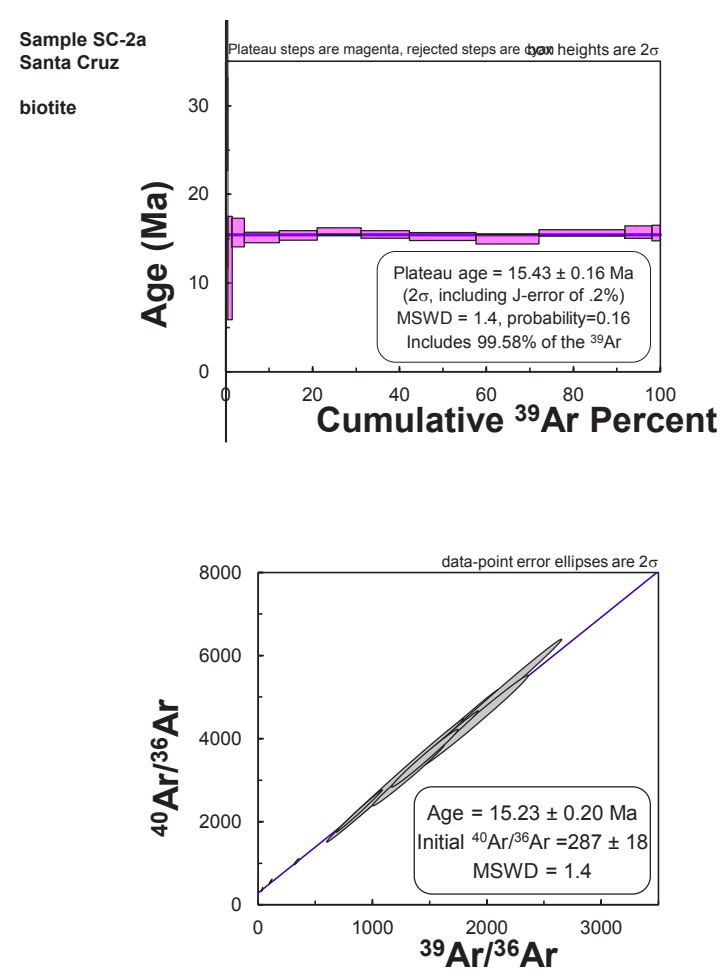
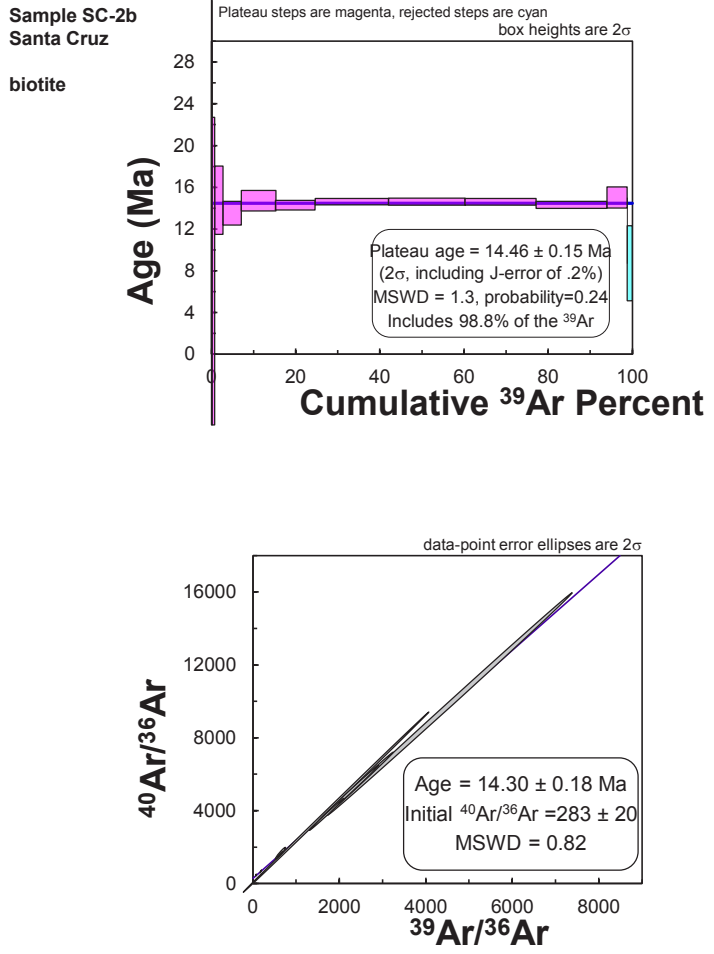


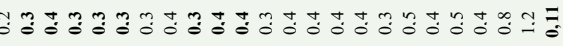

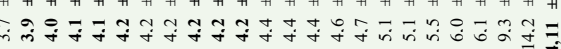

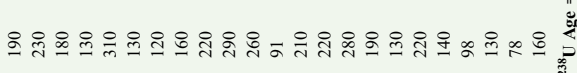

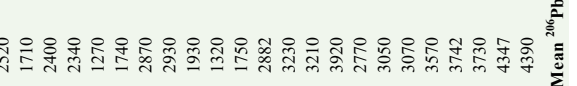

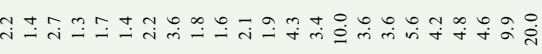

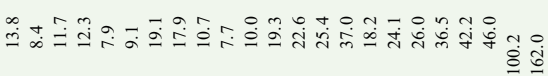

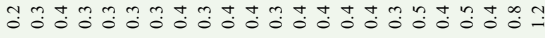

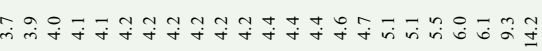

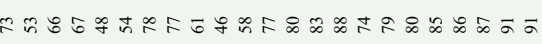

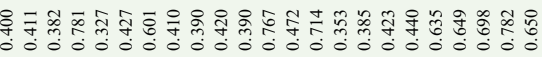

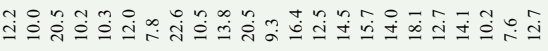
0
0
0
0
0
0
0

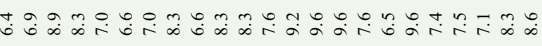

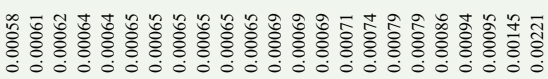

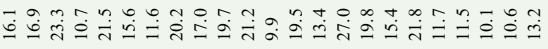

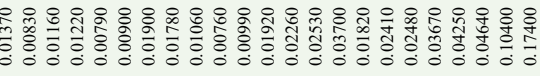

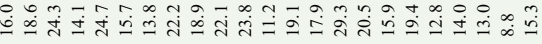

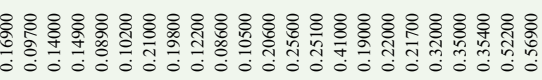

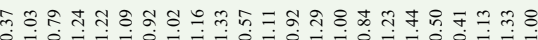

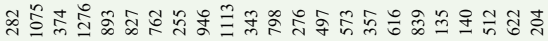

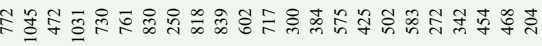

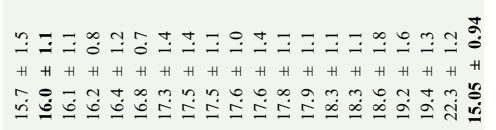

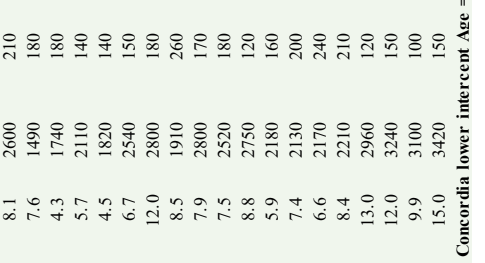

तี่

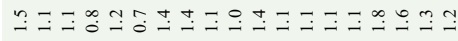

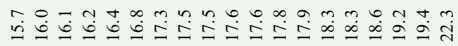

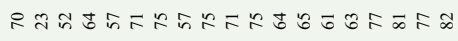

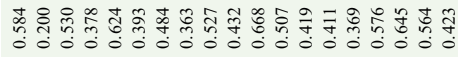

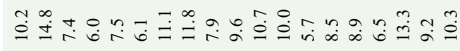

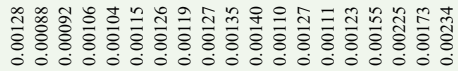

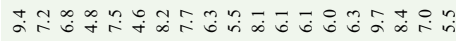

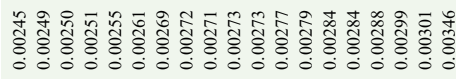

-

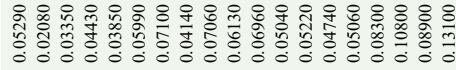

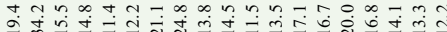

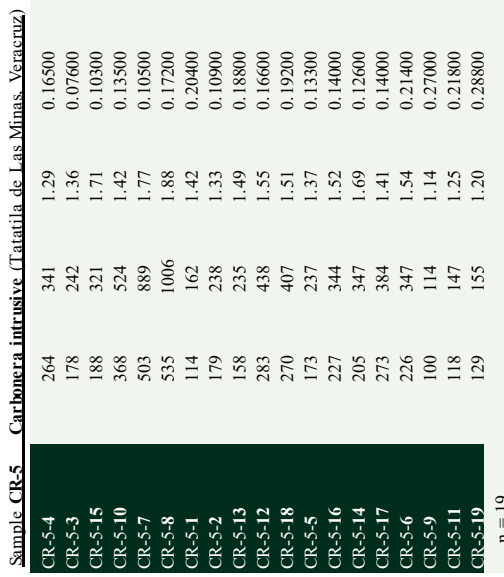

$\frac{\frac{x}{2}}{\frac{2}{a}}$

\& 윰융요 \&

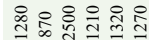

भिं

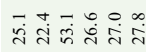

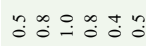

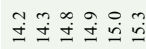

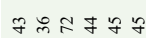

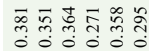

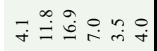

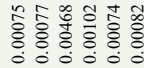

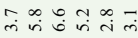

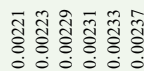

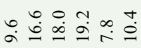

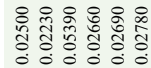

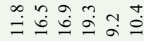

章 


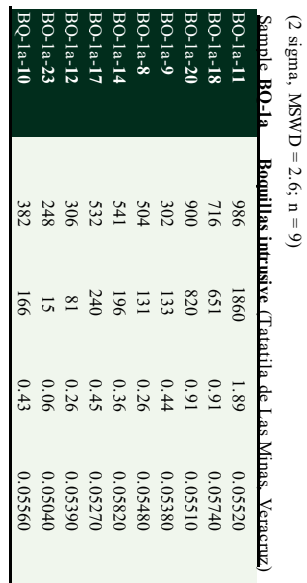

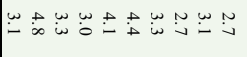

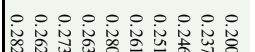

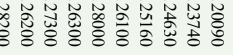

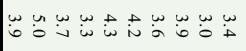

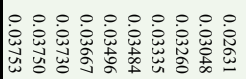

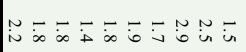

0
0

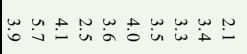

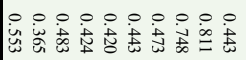

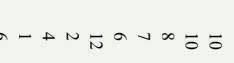

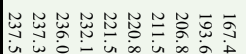

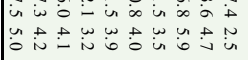

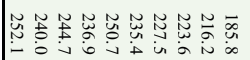

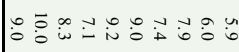

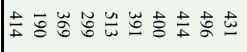

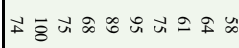

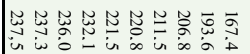

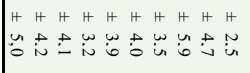

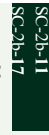

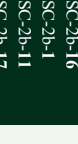

\section{ะัด ํํำ}

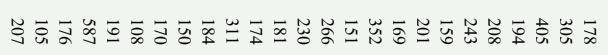

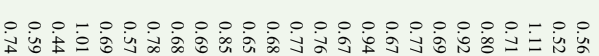

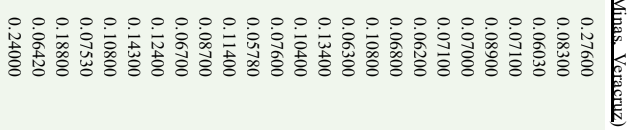

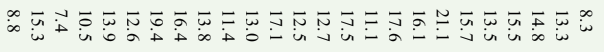

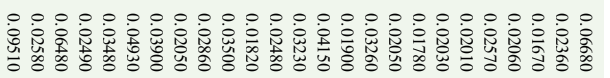

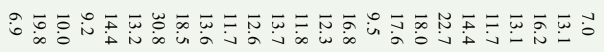

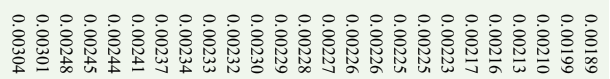

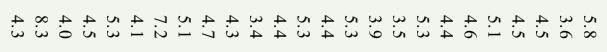

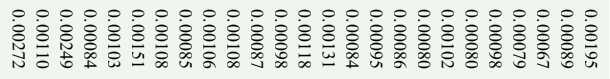

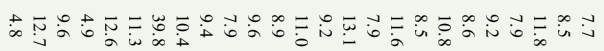

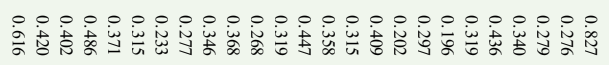

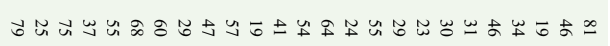

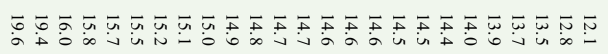

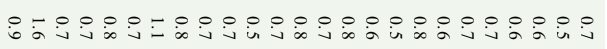

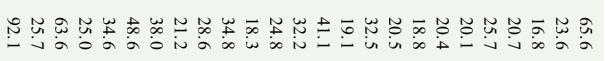

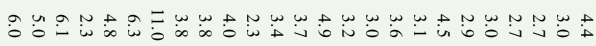

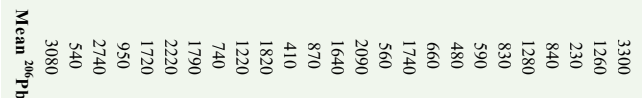

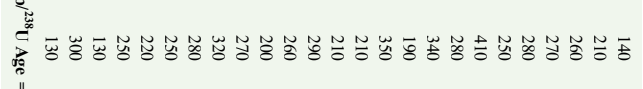

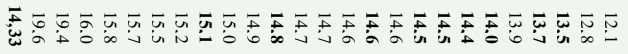

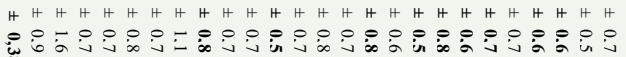

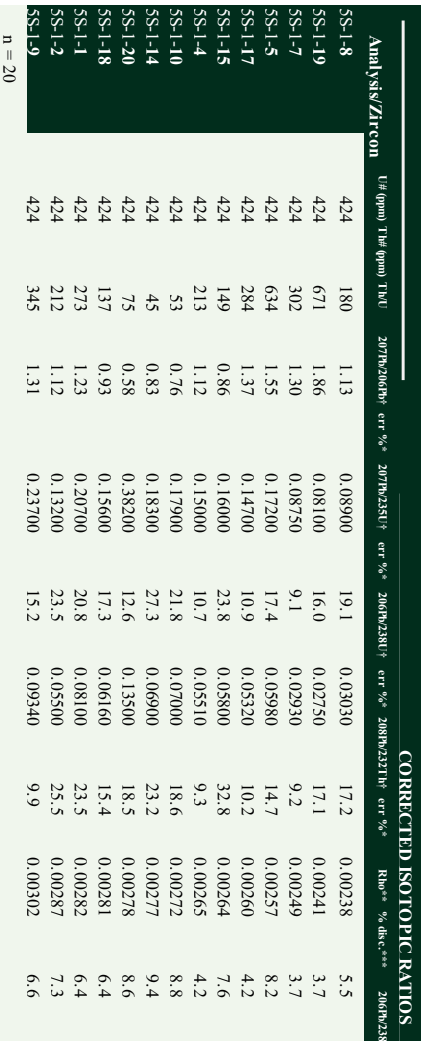

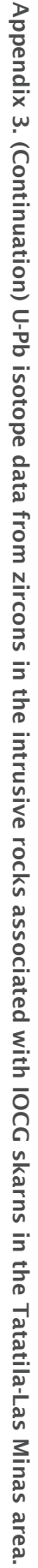
每

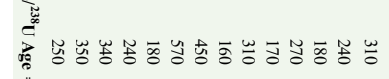

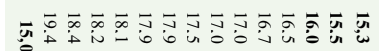

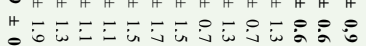




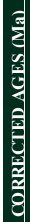

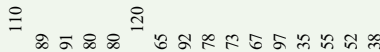

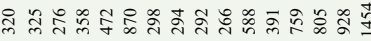

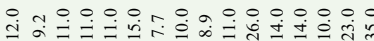

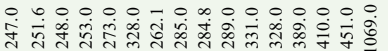

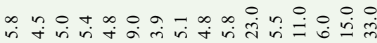

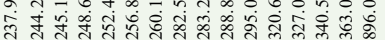

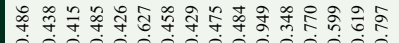

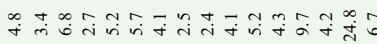

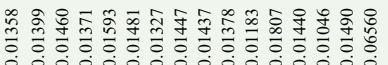

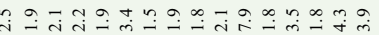

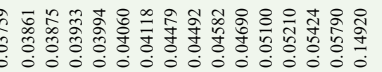

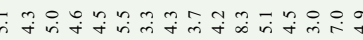

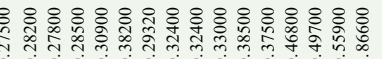

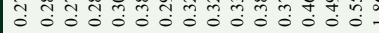

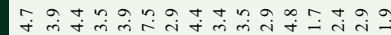

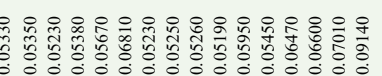

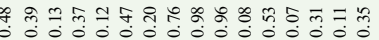

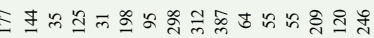

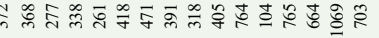

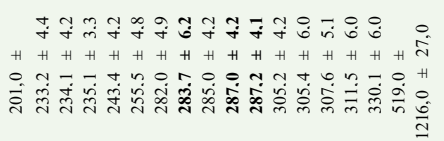

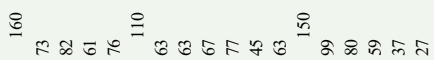

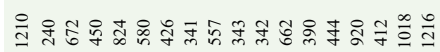

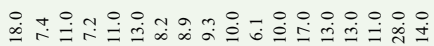

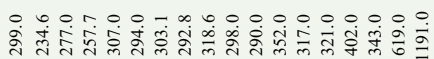

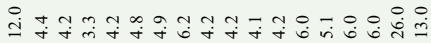

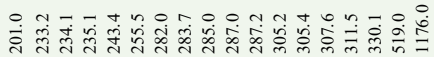

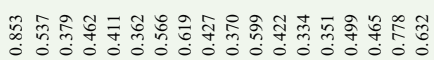

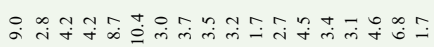

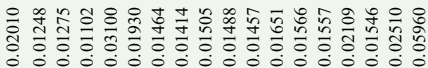

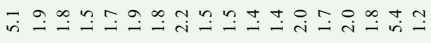

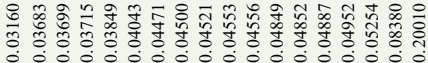

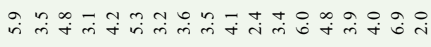

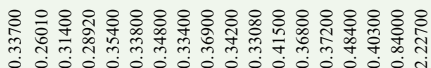

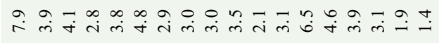
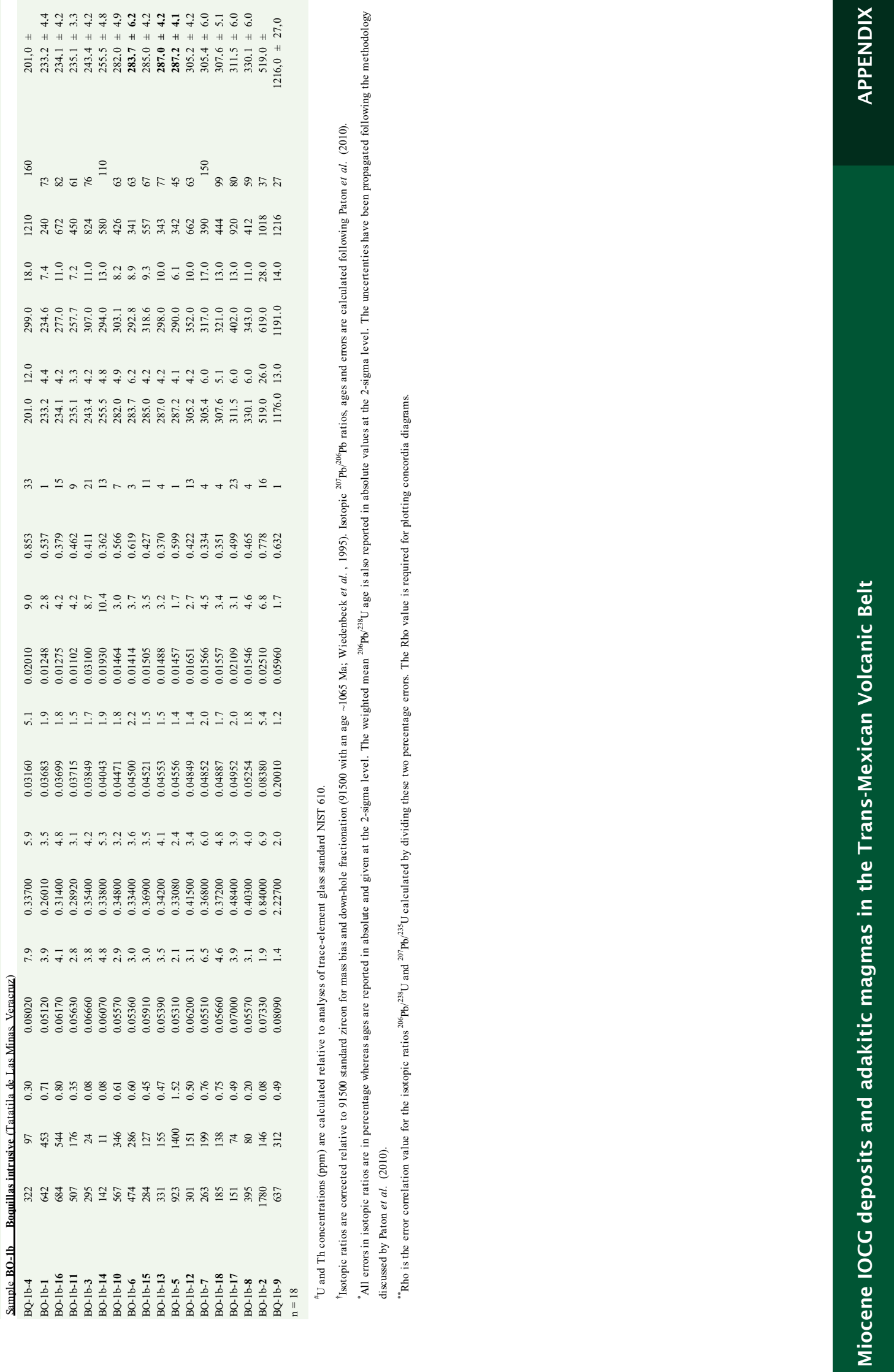


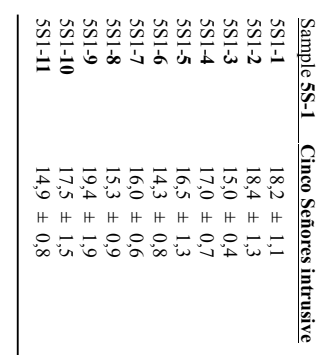

亏ัฐ

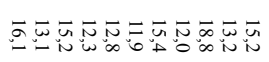

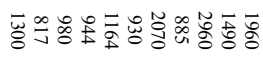

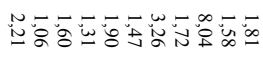

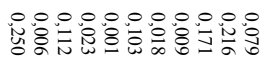

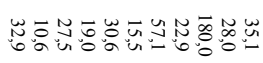

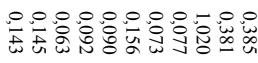

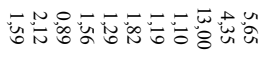

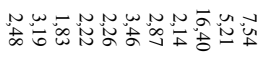

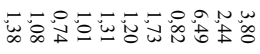

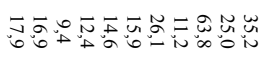

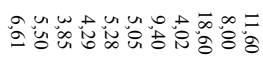

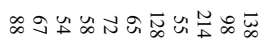

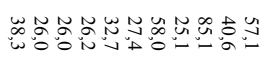

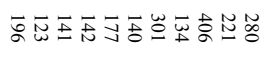

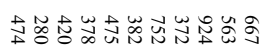

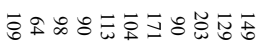

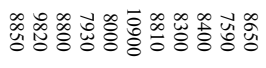

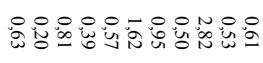

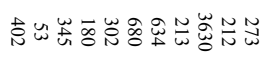

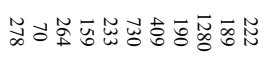

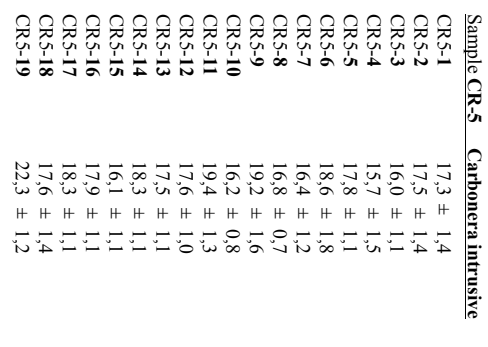

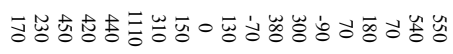

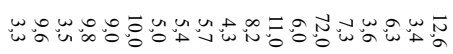

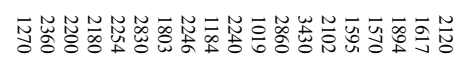

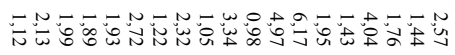

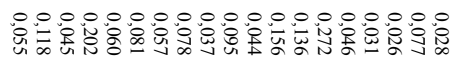

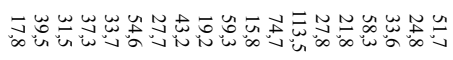

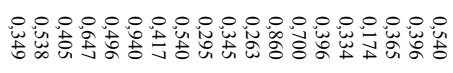

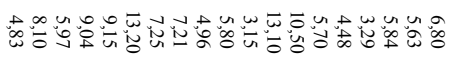

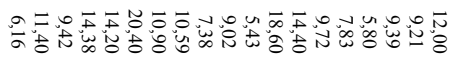

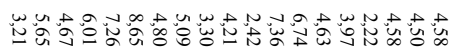

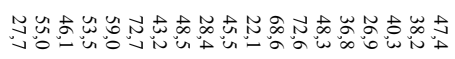

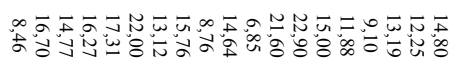

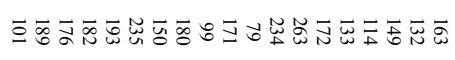

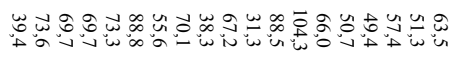

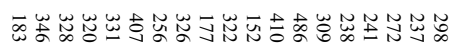

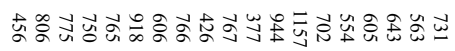

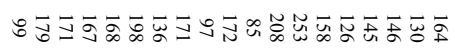

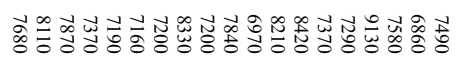

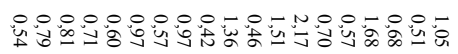

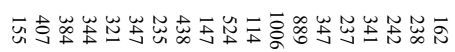

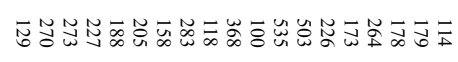

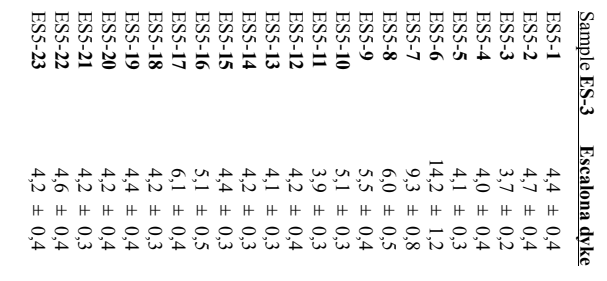

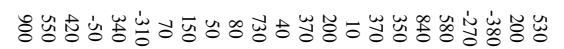

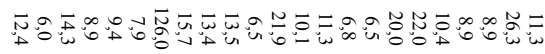

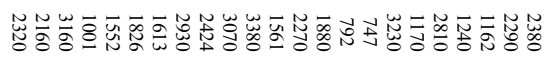

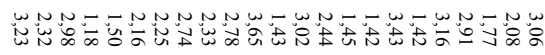

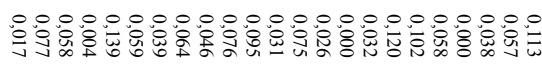

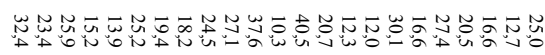

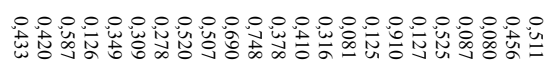

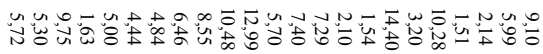

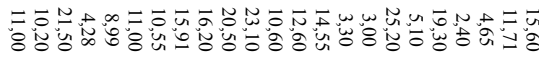

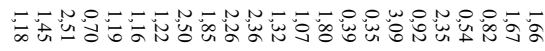

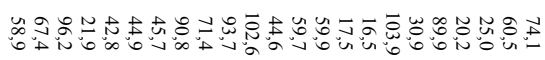

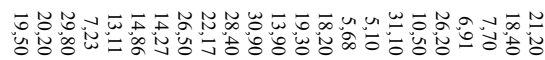

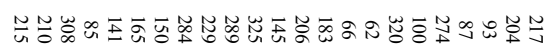

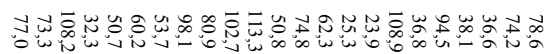

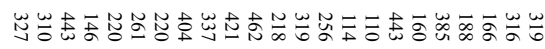

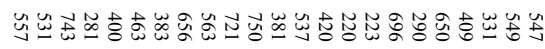

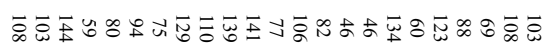

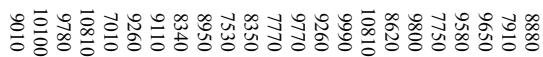

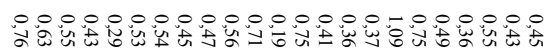

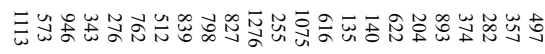

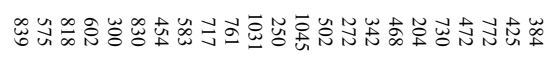




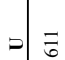

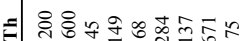

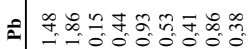

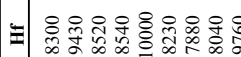

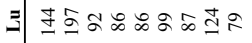

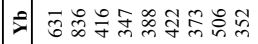

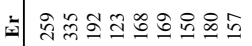

에

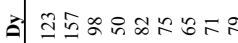

$F$ Fin

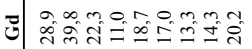

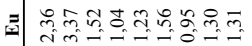

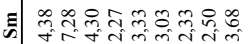

च

$=2$

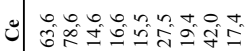

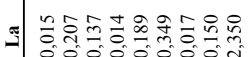

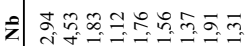

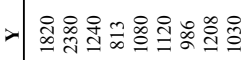

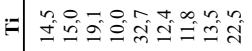

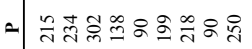

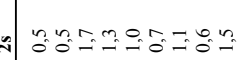

H $+1+1+1+1+H+1+4$

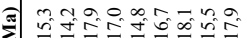

高

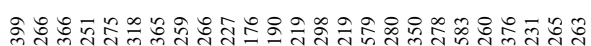

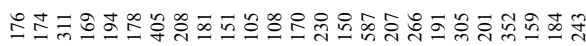

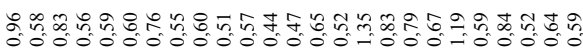

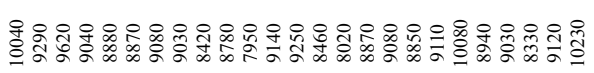

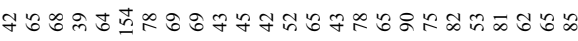

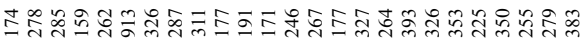

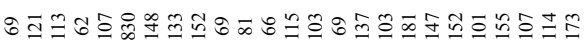

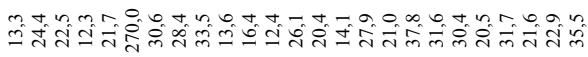

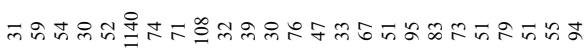

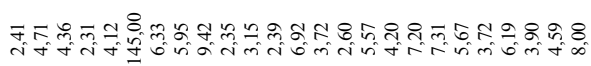

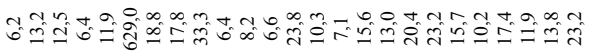

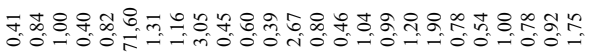

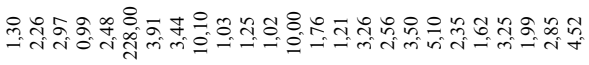

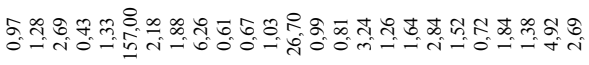

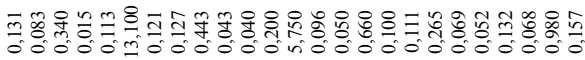

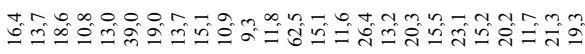

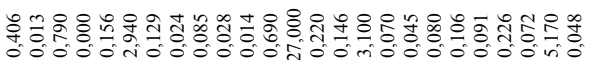

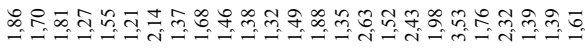

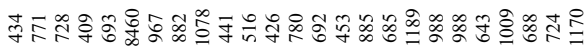

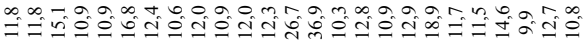

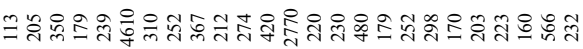

:

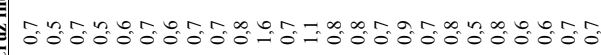

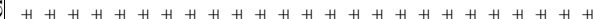

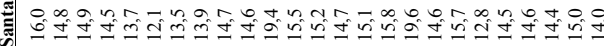

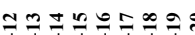

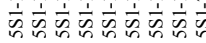

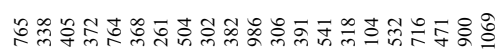

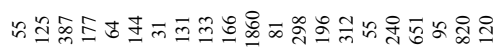

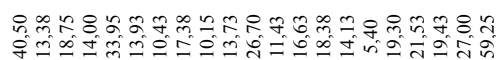

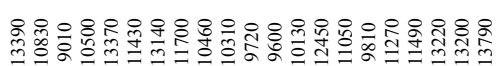

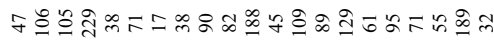

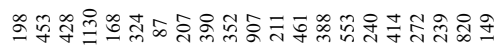

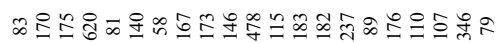

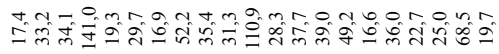

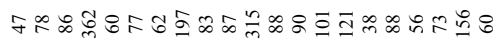

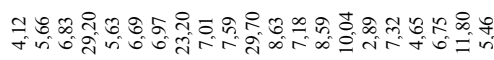

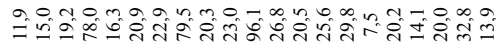

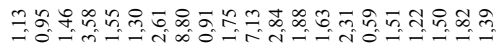

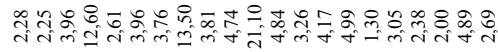

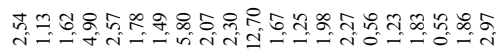

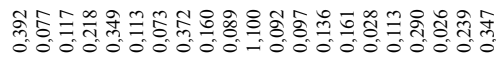

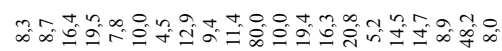

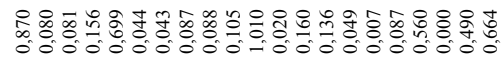

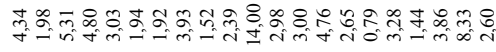

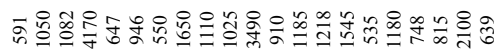

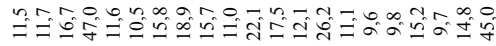

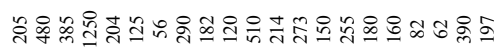

:

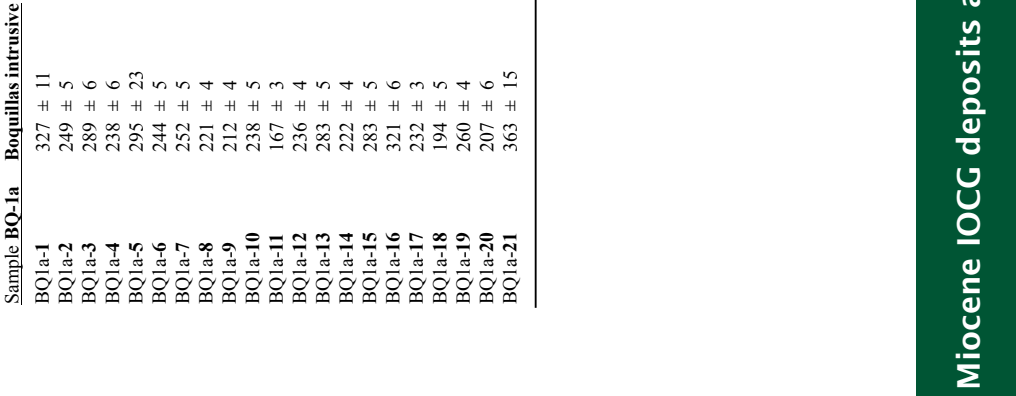




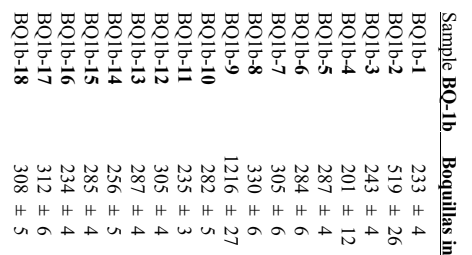

